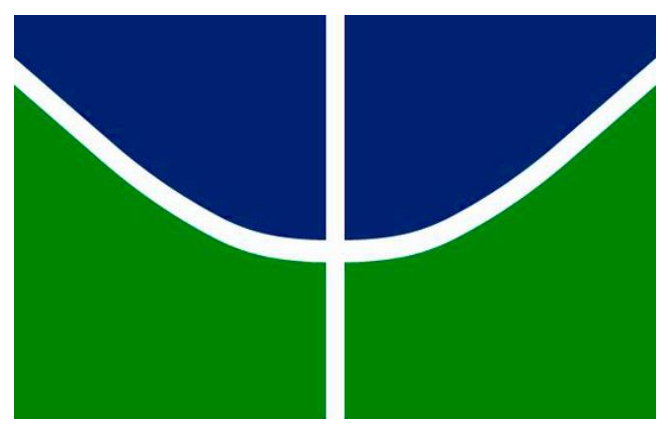

UNIVERSIDADE DE BRASÍLIA

PROGRAMA DE PÓS-GRADUAÇÃO EM PATOLOGIA MOLECULAR

\title{
CARACTERIZAÇÃO DOS EFEITOS ANTITUMORAIS DE COMPOSTOS DERIVADOS DO ÁCIDO ANACÁRDICO EM LINHAGENS CELULARES DE ADENOCARCINOMA DE MAMA
}

ERIKA PEREIRA SAMPAIO

BRASÍLIA

Março, 2015 


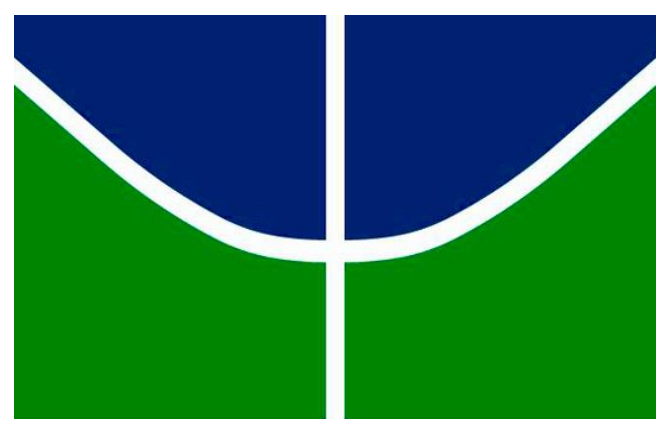

UNIVERSIDADE DE BRASÍLIA

PROGRAMA DE PÓS-GRADUAÇÃO EM PATOLOGIA MOLECULAR

\author{
ERIKA PEREIRA SAMPAIO
}

CARACTERIZAÇÃO DOS EFEITOS ANTITUMORAIS DE COMPOSTOS DERIVADOS DO ÁCIDO ANACÁRDICO EM LINHAGENS CELULARES DE ADENOCARCINOMA DE MAMA

Dissertação apresentada à Universidade de Brasília como parte dos requisitos necessários para a obtenção do Título de Mestre em Patologia Molecular.

Orientadora: Kelly Grace Magalhães

Co-orientador: José Raimundo Corrêa 


\title{
ERIKA PEREIRA SAMPAIO
}

\author{
CARACTERIZAÇÃO DOS EFEITOS ANTITUMORAIS DE COMPOSTOS DERIVADOS DO \\ ÁCIDO ANACÁRDICO EM LINHAGENS CELULARES DE ADENOCARCINOMA DE MAMA
}

Dissertação apresentada à Universidade de Brasília como parte dos requisitos necessários para a obtenção do Título de Mestre em Patologia Molecular.

Aprovado em

BANCA EXAMINADORA

Profa. Dra. Kelly Grace Magalhães (Presidente)

Profa. Dra. Andrea Barreto Motoyama (Membro Efetivo)

Prof. Dr. Guilherme Martins Santos (Membro Efetivo)

Prof. Dr. Luiz Romeiro (Membro Suplente) 
"Por vezes sentimos que aquilo que fazemos não é senão uma gota de água no mar. Mas o mar seria menor se lhe faltasse uma gota".

Madre Teresa de Calcutá 


\section{AGRADECIMENTOS}

Agradeço primeiramente a Deus por me amparar nos momentos difíceis, me dar força interior para superar as dificuldades, mostrar o caminho nas horas incertas e me suprir em todas as minhas necessidades.

Aos meus pais Érico e Sandra, e irmãos Sylvia e Victor por me incentivarem sempre. Ao Pedro por estar ao meu lado me apoiando todos os dias, e por estar disposto a deixar tudo para trás e me acompanhar no meu sonho de fazer doutorado no exterior.

À minha orientadora, professora Kelly Grace Magalhães, por todos os ensinamentos, por incentivar meu crescimento acadêmico e profissional, por acreditar no meu potencial e por ser uma inspiração como docente e pesquisadora.

Ao professor José Raimundo Corrêa, pela orientação e pelos reagentes dispostos.

Aos colegas de bancada do LIMI, pelo auxílio na realização dos experimentos e pela convivência diária.

À Universidade de Brasília e ao Programa de Pós-graduação em Patologia Molecular, pela oportunidade.

Ao CNPq, pelo apoio financeiro. 


\section{SUMÁRIO}

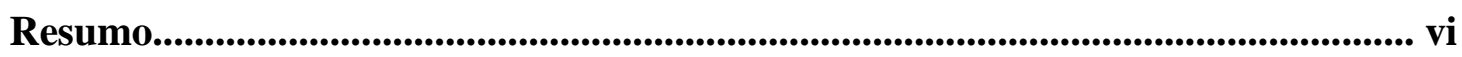

Abstract....................................................................................................................... vii

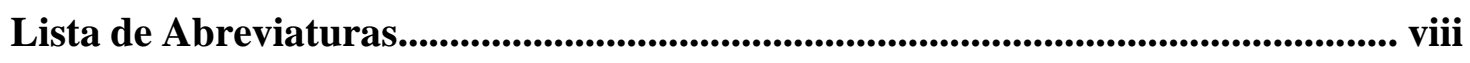

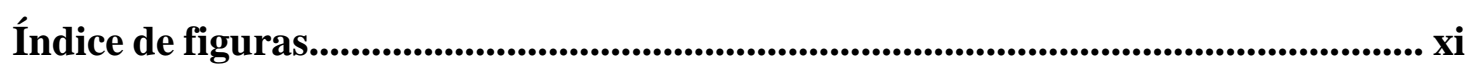

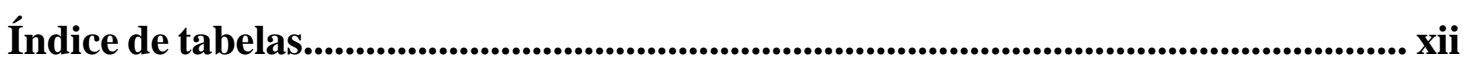

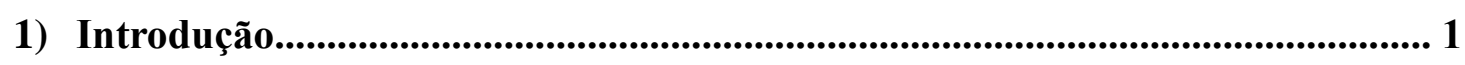

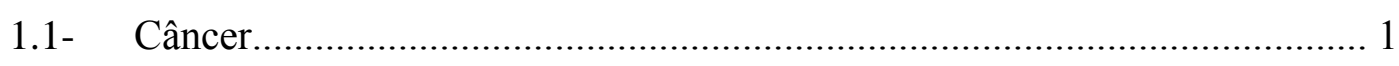

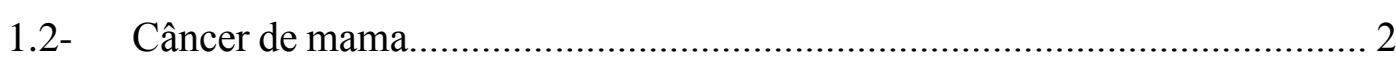

1.3- Resposta imune no câncer...................................................................... 4

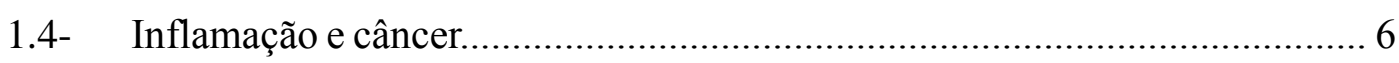

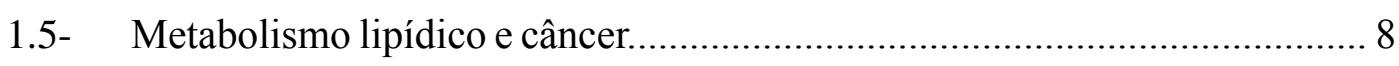

1.6- Corpúsculos lipídicos e câncer............................................................... 9

1.7- Receptores nucleares e câncer............................................................... 10

1.8- PPAR - Receptor Ativado por Proliferador Peroxissomal.......................... 11

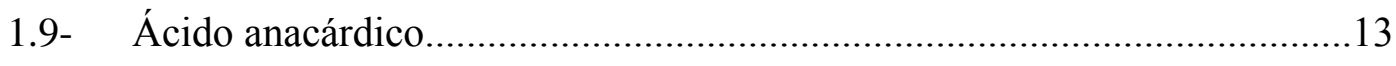

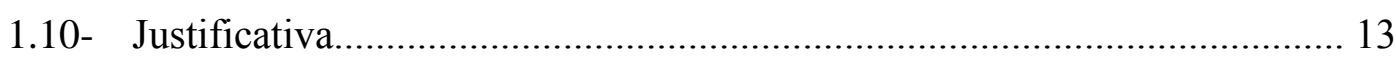

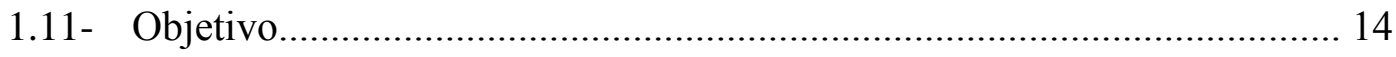

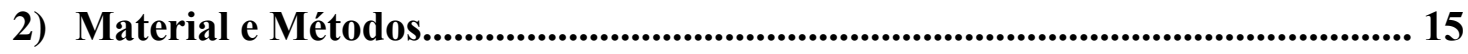

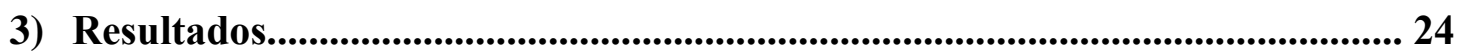

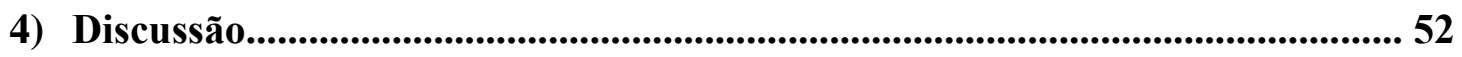

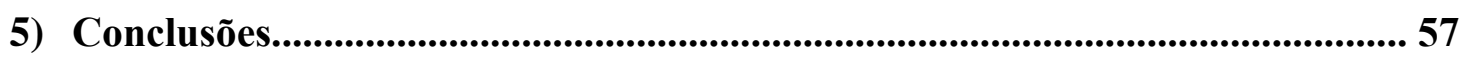

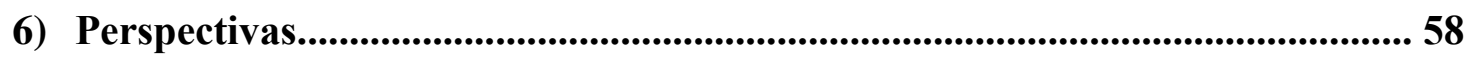

7) Referências...................................................................................................................................59 


\section{RESUMO}

ERIKA PEREIRA SAMPAIO. Caracterização dos efeitos antitumorais de compostos derivados do ácido anacárdico em linhagens celulares de adenocarcinoma de mama. Universidade de Brasília, 2015.

O câncer de mama é o tipo de câncer que mais acomete mulheres em todo o mundo. Muitas drogas tem sido estudadas como potenciais terapias para este tipo de câncer, incluindo agonistas de PPAR $\gamma$ e anti-inflamatórios não-esteróides. A partir do ácido anacárdico, um lipídeo fenólico do líquido da casca da castanha de caju com características anti-inflamatórias, foram sintetizados diferentes agonistas parciais de PPAR $\gamma$. O objetivo deste trabalho foi investigar o efeito de novos derivados do ácido anacárdico, previamente descritos como agonistas parciais de PPAR $\gamma$, na viabilidade, proliferação, ciclo celular e migração de células tumorais de mama. Células MDA-MB-231 e MCF-7, células mononucleares do sangue periférico e células epiteliais de mama MCF-10 foram tratadas com os compostos derivados de ácido anacárdico e comparados com o controle (células sem tratamento). Ensaios para avaliar viabilidade (MTT), proliferação (ensaio clonogênico e CFSE), ciclo celular (PI), migração (wound healing) e apoptose (anexina/PI) foram realizados em células MDA-MB-231. Além disso, também investigamos a ocorrência de alteração na produção de ROS e NO, na biogênese de corpúsculos lipídicos e na expressão de 5LO, NFkB e PPAR $\gamma$ nesta linhagem celular após estímulo com os compostos LDT11, LDT13, LDT380 e LDT383. Após o tratamento com o composto LDT13, foi observada uma redução significativa na viabilidade de MCF-7 e MDA-MB-231, assim como diminuição na proliferação, enquanto a viabilidade de MCF-10 não foi afetada. O tratamento com os compostos LDT11, LDT13, LDT380 e LDT383 reduziram a viabilidade, aumentaram a apoptose, reduziram a proliferação e migração de MDA-MB-231 e promoveram alterações no ciclo celular. Os compostos LDT13 e LDT383 aumentaram a expressão de PPAR $\gamma$, enquanto LDT11 e LDT380 não o fizeram. O composto LDT13 aumentou a produção de ROS e NO,

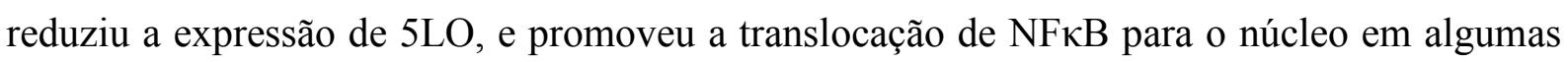
células. Nossos dados sugerem que o composto LDT13 pode ser um candidato para testes clínicos e um agente terapêutico promissor para o tratamento de câncer de mama.

Palavras chave: ácido anacárdico, câncer de mama, novas drogas 


\section{ABSTRACT \\ ERIKA PEREIRA SAMPAIO. Characterization of the antitumoral effects of anacardic acid derivatives in breast cancer cell lines. University of Brasília, 2015.}

Breast cancer is the type of cancer that affects more women in the world. Many drugs have been studied as potential therapies for this type of cancer, including PPAR $\gamma$ agonists and nonsteroidal anti -inflammatory drugs. From the anacardic acid, an phenolic lipid of the cashew nutshell liquid with anti-inflammatory properties, were synthesized different partial agonists of PPAR $\gamma$. The aim of this study was to investigate the effects of new anacardic acid derivatives, which were previously described as PPAR $\gamma$ partial agonists, on breast cancer cell lines viability, proliferation, cell cycle and migration. MDA-MB-231 and MCF-7 breast cancer cell-lines and nontumorigenic PBMCs and MCF-10 human mammary epithelial cells were treated with anacardic acid derivatives and compared with negative control (without treatment). Assays to evaluate viability (MTT), proliferation (CFSE and clonogenic assay), cell cycle (PI), migration (wound healing) and apoptosis (annexin v/ PI) were performed in MDA-MB-231. Moreover, we analyzed de occurrence of alterations in the production of ROS and NO, lipid bodies biogenesis, and 5LO, NFkB and PPAR $\gamma$ expression after treatment with LDT11, LDT13, LDT380 and LDT383. After treatment with the compound LDT13, we observed a significant reduction in MCF-7 and MDA-MB-231 viability, as well as a decrease in proliferation and cell cycle alterations, while MCF-10 viability was not affected. The treatment with the drugs LDT11, LDT13, LDT380 and LDT383 reduced viability, increased apoptosis, reduced proliferation and migration of MDA-MB-231 cells and promoted cell cycle alterations. LDT13 and LDT383 increased the expression of PPAR $\gamma$, while LDT11 and LDT380 did not. LDT13 increased the production of ROS and NO, reduced the expression of 5LO, and promoted the translocation of NFkB in some cells. Our data suggest that new anacardic acid derivative LDT13 may be a strong candidate for breast cancer clinical trials and a promising therapeutic agent.

Key words: Anacardic acid, breast cancer, new drugs 


\section{$\underline{\text { Lista de Abreviaturas e Siglas }}$}

AA Ácido araquidônico

AINE Anti-inflamatórios não-esteróides

APC Proteína de polipose coli adenomatosa

AP2 Proteína ligadora de ácido graxo do adipócito

ARG Arginina

BRCA1 Proteína do tipo 1 de susceptibilidade ao câncer de mama

BRCA2 Proteína do tipo 2 de susceptibilidade ao câncer de mama

${ }^{\circ} \mathrm{C} \quad$ Graus Celsius

CFSE Carboxifluoresceina succinimidil Ester

COX2 Ciclo-oxigenase 2

DFC-DA 2'7’ Diclorodihidrofluoresceína-diacetato

DMEM Meio de Eagle modificado por Dulbecco

DMSO Dimetilsulfóxido

DNA Ácido desoxirribonucléico

EDTA Ácido etilenodiamino tetra-acético

ER Receptor de estrógeno

FATp Proteína transportadora de ácidos graxos

FITC Fluoresceína

FT Fator de transcrição

HETE Ácido hidroxoeicosatetraenoico

HODE Ácido hidroxioctadecadienoico

IARC Agência Internacional de pesquisa em câncer

ICAM Molécula de adesão intercelular 
IFN- $\gamma \quad$ Interferon-gamma

IgG Imunoglobulina $\mathrm{G}$

IL1 Interleucina 1

IL6 Interleucina 6

IL8 Interleucina 8

INCA Instituto Nacional de Câncer

LO Lipoxigenase

LPL Proteína lípase

LTB4 Leucotrieno B4

MTT 3-(4,5-Dimetiltiazol-2-yl)-2,5-difeniltetrazolio brometo

NFкB Fator nuclear kappa B

OMS Organização Mundial de Saúde

PBS Tampão fosfato salino

PGD2 Prostaglandina D2

PGE2 Prostaglandina E2

PGF2 Prostaglandina F2

PGJ2 Prostaglandina J2

PI Iodeto de propídeo

PPAR Receptor Ativado por Proliferador Peroxissomal

PPRE Elemento Responsivo ao PPAR

PR Receptor de progesterona

RE Retículo endoplasmático

RN Receptor nuclear

ROS Espécies reativas de oxigênio

RXR Receptor do ácido 9-cis-retinóico 
SER Serina

SDS Dodecil sulfato de sódio

SFB Soro fetal bovino

TBS Solução salina tamponada com Tris

TLA Tampão de ligação de anexina

TNF Fator de necrose tumoral

TXA2 Tromboxano A2

TXB2 Tromboxano B2

TYR Tirosina

TZD Tiazolidinas 


\section{$\underline{\text { Índice de figuras }}$}

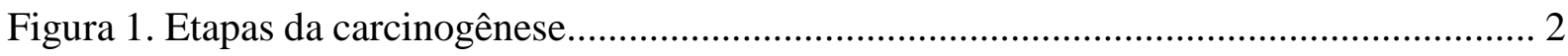

Figura 2. Relação entre o desenvolvimento neoplásico e o sistema imune............................... 6

Figura 3. Correlação entre inflamação e câncer...................................................................... 7

Figura 4. Comparação das médias de viabilidade de MCF-7 ................................................... 25

Figura 5. Comparação das médias de viabilidade de MDA-MB-231 ...................................... 25

Figura 6. Comparação das médias de viabilidade de MCF-10............................................... 26

Figura 7. Comparação das médias de viabilidade de PBMC ................................................... 26

Figura 8. Padrões de proliferação de células MCF-7 sob o estímulo de $10 \mu \mathrm{M}$ dos compostos

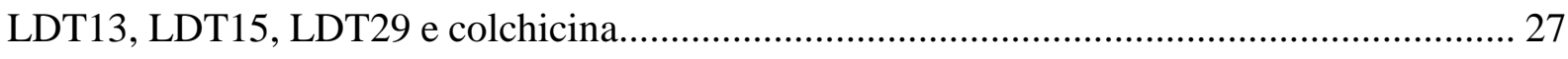

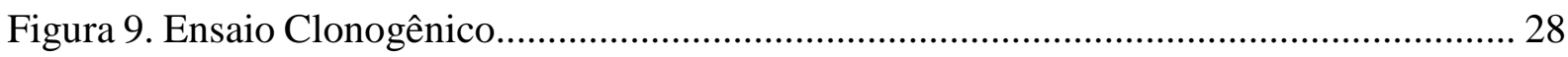

Figura 10. Redução na viabilidade celular de MDA-MB-231 pela estimulação com LDT11,

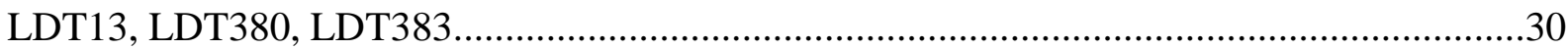

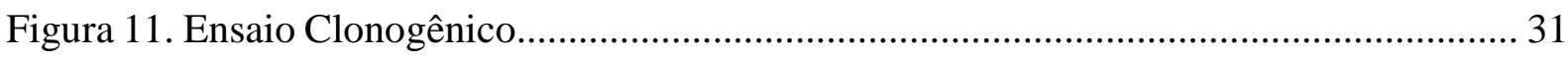

Figura 12. Imagem de microscopia de contraste de fase de células MDA-MB-231................ 33

Figura 13. Morte celular de células MDA-MB-231 ........................................................... 35

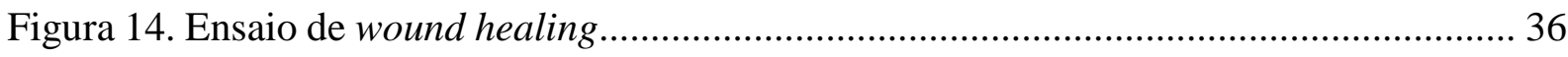

Figura 15. Variação na distribuição de células em diferentes etapas do ciclo celular............... 37

Figura 16. Indução de fragmentação nuclear após estimulação com LDT11, LDT13, LDT380 e

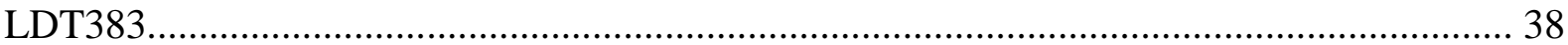

Figura 17. Análise das alterações da quantidade de produção de espécies reativas de oxigênio

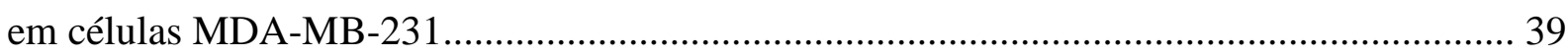

Figura 18. Biogênese de corpúsculos lipídicos em células MDA-MB-231............................... 40

Figura 19. Produção de Óxido Nítrico em células MDA-MB-231 ........................................... 41

Figura 20. Expressão de PPAR $\gamma$ em MDA-MB-231 após estímulo com LDT11, LDT13,

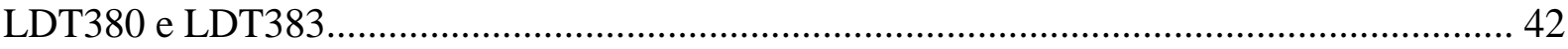

Figura 21. Expressão de 5-LO em células MDA-MB-231 após estímulo com LDT11, LDT13,

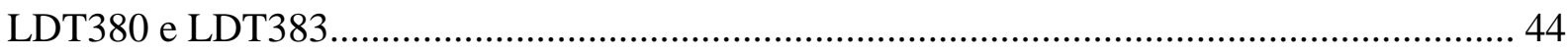

Figura 22. Translocação de NFkB para o núcleo em MDA-MB-231 .......................................46

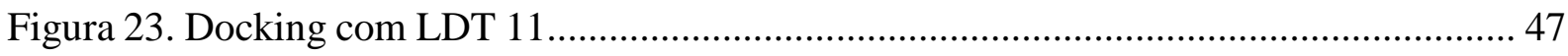

Figura 24. Docking com LDT11 e o ligante 9-(S)-HODE................................................... 47 


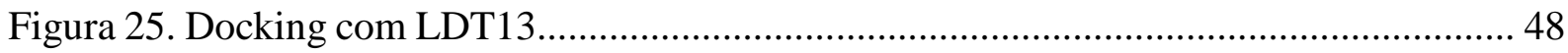

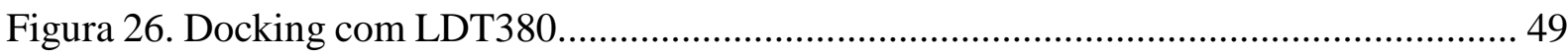

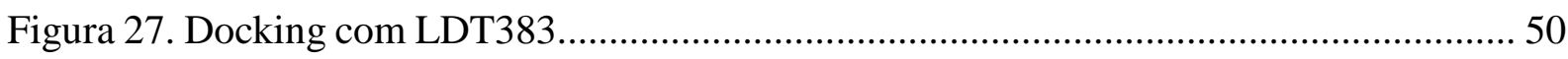

Figura 28. Interferência de ROS nas vias de sinalização de NFאB........................................ 55 


\section{Índice de tabelas}

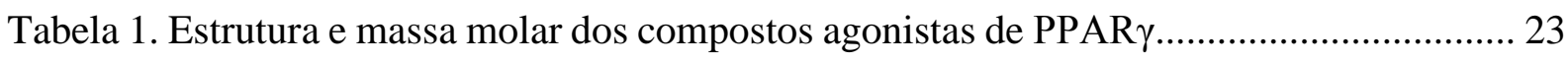

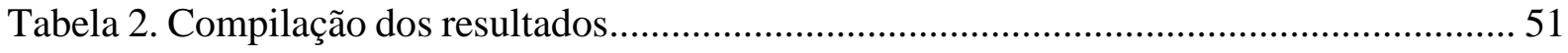




\section{INTRODUÇÃO \\ 1.1 Câncer}

O câncer é um importante problema de saúde pública em todo o mundo, sendo responsável por 8.2 milhões de mortes em 2012 (OMS, 2013). O termo câncer é utilizado genericamente para representar um conjunto de mais de 100 doenças, incluindo tumores malignos de diferentes localizações. Importante causa de doença e morte no Brasil, desde 2003, as neoplasias malignas constituem-se na segunda causa de morte na população, representando mais de 15\% dos óbitos de causa conhecida, notificados em 2011 no Sistema de Informações sobre Mortalidade (BRASIL, 2014).

Segundo estimativas mundiais do projeto Globocan 2012, da Agência Internacional para Pesquisa em Câncer (IARC, do inglês International Agency for Research on Cancer), da Organização Mundial da Saúde (OMS), o impacto global do câncer mais que dobrou em 30 anos. Em 2012 ocorreram 14,1 milhões de casos novos de câncer no mundo. O contínuo crescimento populacional, bem como seu envelhecimento, afetará de forma significativa o impacto mundial do câncer. Em 2030, estima-se que o número de casos mundiais será de 21,4 milhões de casos novos de câncer e 13,2 milhões de mortes por câncer, em consequência do crescimento e do envelhecimento da população, bem como da redução na mortalidade infantil e nas mortes por doenças infecciosas em países em desenvolvimento (BRASIL, 2014).

No Brasil, a estimativa para o ano de 2014, que será válida também para o ano de 2015, aponta para a ocorrência de aproximadamente 576 mil casos novos de câncer, reforçando a magnitude do problema do câncer no país. O câncer de pele do tipo não melanoma (182 mil casos novos) será o mais incidente na população brasileira, seguido pelos tumores de próstata (69 mil), mama feminina (57 mil), cólon e reto (33 mil), pulmão (27 mil), estômago (20 mil) e colo do útero (15 mil) (BRASIL, 2014).

$\mathrm{O}$ câncer caracteriza-se por modificações progressivas no perfil biológico da célula, com alterações na sua capacidade de proliferação, diferenciação, sobrevida e interação com o meio ambiente. Tem origem em uma célula, como resultado do acúmulo de anormalidades (mutações), os quais ocorrem em genes funcionais, como aqueles envolvidos no controle do ciclo celular, na apoptose ou no reparo do DNA, onde leva à perda progressiva da homeostase e ao aparecimento do fenótipo celular maligno (CAMARGO, 2003 apud FROES, 2009). A carcinogênese é o processo pelo qual células normais se transformam em células cancerosas. Este processo passa por várias etapas antes de chegar ao tumor maligno, e pode ser dividido em 3 fases: iniciação, promoção e progressão (FABER, 1984).

A fase de iniciação é caracterizada por danos ao DNA, que podem ser causados por 
agentes físicos (radiação ionizante e luz ultravioleta), químicos ou biológicos (vírus). Esse processo é irreversível e as mutações resultantes dele causam a ativação de oncogenes e a inativação de genes supressores tumorais. Além disso, agentes intracelulares como espécies reativas de oxigênio, provenientes do metabolismo oxidativo normal, e alterações em enzimas metabolizadoras, podem produzir moléculas reativas capazes de induzir danos genotóxicos (SURH, 2003; MEHTA et al., 2010).

$\mathrm{Na}$ fase de promoção, ocorre a expansão pelo crescimento das células mutantes por um estímulo à proliferação celular, que pode ser decorrente da liberação de fatores de crescimento. Este processo é reversível e mais lento, e se caracteriza pela desregulação de vias de sinalização que normalmente controlam a proliferação celular e a apoptose. Por fim, a fase de progressão é caracterizada pelo acúmulo de alterações genéticas, angiogênese e desenvolvimento de metástases (MEHTA et al., 2010).

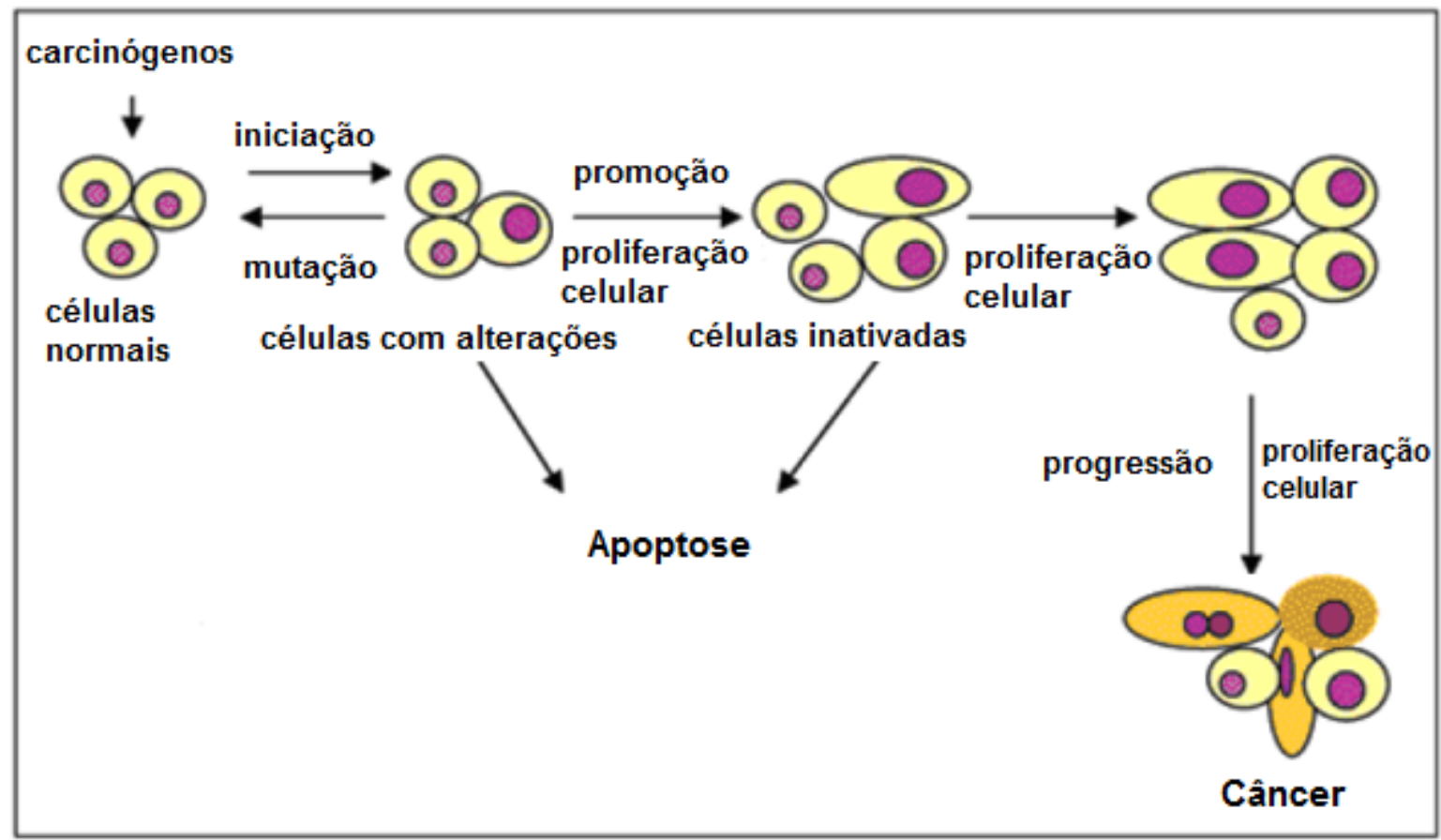

Figura1. Etapas da carcinogênese. Esquema mostrando as fases do desenvolvimento neoplásico. Adaptado de OLIVEIRA et al, 2007.

\subsection{Câncer de mama}

O câncer de mama é o tipo de câncer que mais acomete as mulheres, tanto em países em desenvolvimento quanto em países desenvolvidos. Cerca de 1,67 milhões de casos novos dessa neoplasia foram esperados para o ano de 2012, em todo o mundo, o que representa $25 \%$ de todos os tipos de câncer diagnosticados nas mulheres.

A maioria dos cânceres de mama têm origem no epitélio ductal, com carcinomas 
ductais infiltrantes sendo responsáveis por mais de $70 \%$ dos casos de câncer de mama, enquanto a minoria se origina do epitélio lobular (HARRIS et al., 1992). Nos últimos 40 anos, a sobrevida vem aumentando nos países desenvolvidos e, atualmente, é de $85 \%$ em cinco anos, enquanto, nos países em desenvolvimento, permanece com valores entre $50 \%$ e $60 \%$. O câncer de mama é a maior causa de morte por câncer nas mulheres em todo o mundo, com cerca de 520 mil mortes estimadas para o ano de 2012. É a segunda causa de morte por câncer nos países desenvolvidos, atrás somente do câncer de pulmão, e a maior causa de morte por câncer nos países em desenvolvimento (INCA, 2014).

Para o Brasil, em 2014, são esperados 57.120 casos novos de câncer de mama, com um risco estimado de 56,09 casos a cada 100 mil mulheres (INCA, 2014).

Sem considerar os tumores de pele não melanoma, esse tipo de câncer é o mais frequente nas mulheres das regiões Sudeste (71,18/ 100 mil), Sul (70,98/ 100 mil), CentroOeste (51,30/ 100 mil) e Nordeste (36,74/ 100 mil). Na região Norte, é o segundo tumor mais incidente (21,29/100 mil) (INCA, 2014).

A gênese do câncer de mama é multifatorial. São identificados diversos fatores de risco, entre os quais podemos destacar: sexo feminino, idade superior aos 45 anos, história pregressa de câncer de mama ou de biópsia mamária atípica, menarca precoce, menopausa tardia, nuliparidade, primeira gestação depois dos 35 anos, uso prolongado de terapia de reposição hormonal (TRH), exposição à radiação ionizante, obesidade, tabagismo, etilismo e suscetibilidade genética.

A história familiar de câncer de mama está associada a um aumento no risco de cerca de duas a três vezes para o desenvolvimento desse tipo de neoplasia (INCA, 2014). Aproximadamente 5 a $10 \%$ dos casos de câncer de mama e ovário são hereditários e até 50\% desses são causados por mutações genéticas. Mulheres portadoras de mutações nos genes BRCA1 e BRCA2 estão particularmente susceptíveis ao surgimento dessas neoplasias. O risco de carcinoma mamário antes dos 35 anos varia de 45 a $60 \%$ para portadores de mutações no BRCA1, e de 25 a 40\% para portadores de mutações no BRCA2 (FERLA et al, 2007). Dependendo dos índices da mutação no gene BRCA1, o risco pode ultrapassar $80 \%$ aos 70 anos de idade (SAADATMAND et al, 2014).

A influência hormonal também é bastante importante no desenvolvimento do câncer de mama. Desde 1896 sabe-se que esta neoplasia é hormônio dependente, quando Beatson mostrou através de seus experimentos que com a retirada dos ovários ocorre a regressão da disseminação do câncer mamário (BEATSON, 1896). 


\subsection{Resposta imune no câncer}

O sistema imune possui grande importância na prevenção do desenvolvimento de tumores, estando apto a identificar ameaças à homeostase orgânica, e reagir de forma a eliminar, neutralizar ou tolerar ações prejudiciais.

As interações que ocorrem entre células cancerosas e células do sistema imune no microambiente tumoral são complexas, e existem diversas diferenças entre a resposta imunológica de um indivíduo para o outro. Em algumas pessoas a resposta imune pode inibir o crescimento tumoral levando a remissões espontâneas, e em outras pode promover inflamação crônica induzindo a progressão do câncer e angiogênese (DOUGAN e DRANOFF, 2009).

O papel de células do sistema imune no câncer tem sido bastante pesquisado recentemente, porém a associação entre as células do sistema imune e os tumores é conhecida há tempos. Apesar de vários estudos terem sido realizados, ainda não existe consenso se o papel do sistema imune na tumorigênese é indutor ou protetor. A princípio achava-se que os infiltrados de leucócitos observados ao redor de tumores representavam uma tentativa do hospedeiro em eliminar as células neoplásicas. Em 1909, Paul Ehrlich elaborou o conceito de vigilância imune, que foi consolidado mais tarde em 1957 por Burnet e Thomas (BARONZIO et al., 2009; BURNET, 1957; THOMAS, 1959).

Burnet acreditava que um pequeno acúmulo de células tumorais poderia se desenvolver, e por essas células possuírem antígenos diferentes elas poderiam provocar uma reação imune efetiva com regressão do tumor (BURNET, 1957). Em virtude de tais pensamentos, foi proposta a hipótese de que alterações genéticas hereditárias seriam comuns em células somáticas, e uma proporção dessas mudanças representaria um passo em direção a malignidade. Seria então uma necessidade evolutiva de que houvesse algum mecanismo para a eliminação ou inativação de tais células mutantes potencialmente perigosas, e foi proposto que este mecanismo fosse de caráter imunológico (BURNET,1970).

Segundo a teoria da vigilância imunológica, o sistema imune participa no controle do crescimento tumoral, visto que células imunes podem reconhecer e eliminar clones de células mutantes no organismo antes que elas deem origem à tumores (BARONZIO et al., 2009). 
Realmente, um extenso infiltrado de células matadoras naturais (NK - do inglês, Natural Killer) está associado a um prognóstico melhor em cânceres colorretais ou gástricos (ISHIGAMI et al., 2000). Além disso, indivíduos imunodeprimidos apresentam maior susceptibilidade ao desenvolvimento de câncer, inclusive para tumores não dependentes de infecção viral (GATTIM; GOOD, 1971).

Acredita-se que tanto a imunidade inata quanto a adaptativa participam do processo de erradicação do tumor, formando um sistema integrado de defesas do hospedeiro contra o câncer, no qual várias células e moléculas funcionam simultaneamente. A primeira linha de defesa do hospedeiro contra microrganismos invasores e células tumorais é a imunidade inata, e os principais tipos celulares que a compõe incluem células NK e macrófagos. A resposta imune adaptativa participa na eliminação de patógenos e na defesa do hospedeiro em etapas mais tardias do desenvolvimento neoplásico, sendo o linfócito T o tipo celular com resposta antineoplásica específica contra os antígenos de tumores e responsável pela memória imunológica (LOOSE e VAN DE WIELE, 2009).

O controle de neoplasias durante a resposta imune inata é realizado, principalmente, através da secreção de citocinas (interleucinas - IL, interferon - IFN e fator de necrose tumoral - TNF), bem como ativação de células NK e macrófagos. No momento em que o sistema imune recebe um estímulo, células inflamatórias e linfócitos são ativadas e recrutadas por meio da liberação de quimiocinas e citocinas específicas (SHI et al., 2003). A resposta imune adaptativa está envolvida na eliminação de microorganismos invasores e na defesa do hospedeiro em fases mais tardias do crescimento tumoral, sendo o linfócito $\mathrm{T}$ o tipo celular mais específico contra os antígenos tumorais. Durante a resposta imune adaptativa, o controle de neoplasias é realizado pela ativação de linfócitos TCD8+ os quais liberam grânulos citotóxicos e indutores de apoptose (granzimas, perforinas e granulosimas) diretamente sobre as células tumorais alvos (LOOSE e VAN DE WIELE, 2009).

No entanto, estudos populacionais mostram que pacientes que permanecem com um estado inflamatório crônico tem maiores chances de desenvolver neoplasias. (KARIN e GRETEN, 2005). Em adição a isso, alguns trabalhos mostram que o sistema imune colabora com a promoção do tumor ao selecionar os clones de células neoplásicas de baixa imunogenicidade capazes de evadir a resposta imune (REIMAN et al, 2007; FACIABENNE et al, 2011). 


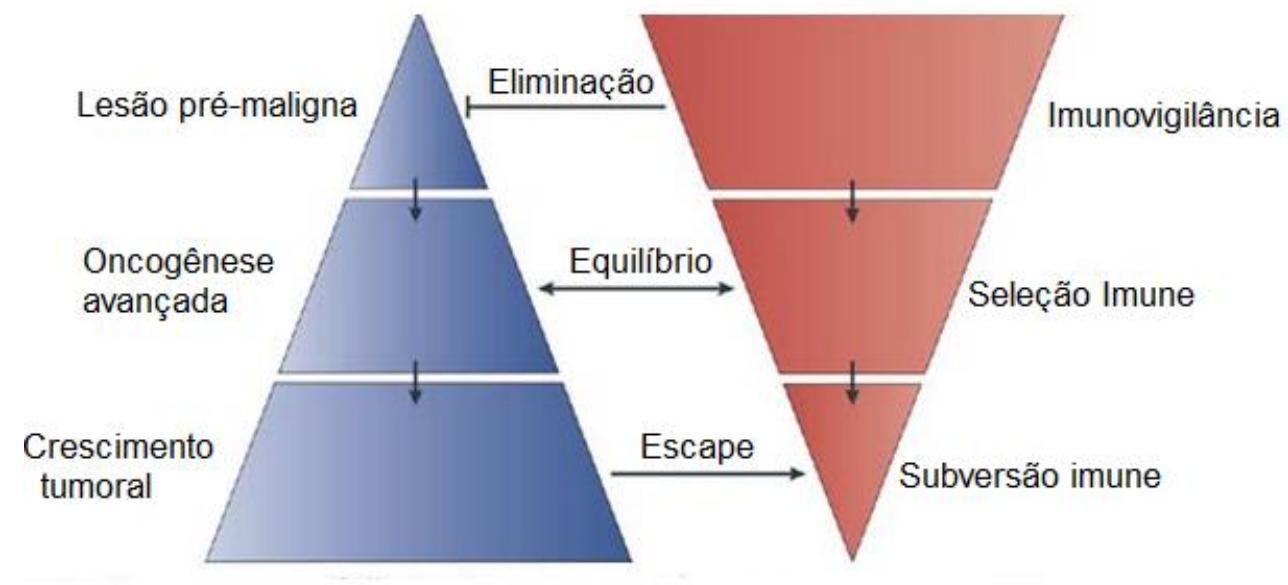

Figura 2. Relação entre o desenvolvimento neoplásico e o sistema imune. A figura mostra de que maneira o desenvolvimento de tumores se inicia a partir de uma relação entre aspectos extrínsecos ao tumor, no caso ações do sistema imune e aspectos intrínsecos às células tumorais, como mutações ou alterações epigenéticas que promovem o desenvolvimento tumoral. Adaptado de ZITVOGEL; TESNIERE; KROEMER, 2006.

Atualmente, a interpretação de um sistema imune bivalente, que ativa tanto a repressão quanto a promoção tumoral vem ganhando cada vez mais adeptos. Alguns estudos enfatizam a coexistência da vigilância imune com um estado inflamatório necessário para a progressão tumoral, definindo-se o todo como um processo de imunoedição (SCHREIBER et al, 2011).

\subsection{Inflamacão e Câncer}

No século XIX, Virchow observou que lesões neoplásicas frequentemente se desenvolvem em sítios de irritação crônica e identificou células do sistema imune em cortes histológicos de tumores. Através de uma síntese dessas observações, ele relacionou o estado inflamatório local com desenvolvimento de neoplasias e propôs uma relação causal entre inflamação e câncer (BALKWILL; MANTOVANI, 2001).

Doenças inflamatórias crônicas podem aumentar o risco de surgimento do câncer. Estudos epidemiológicos estimam que cerca de $15 \%$ dos casos de neoplasias malignas no mundo sejam associados à presença de agentes infecciosos, e a inflamação crônica é um dos principais componentes da infecção causada por esses agentes (BALKWILL; MANTOVANI, 2001).

Atualmente sabe-se que células tumorais têm capacidade de produzir citocinas próinflamatórias e quimiocinas que podem contribuir diretamente para progressão maligna. Sabese que o fator de necrose tumoral (TNF), IL-1, IL-6 e quimiocinas podem ser induzidas por hipóxia, que é uma das condições fisiológicas que costuma estar presente no tecido tumoral e 
ausente no tecido sadio (BALKWILL; MANTOVANI, 2001). Além disso, estudos mostram que o uso prolongado de certos antiinflamatórios (como a aspirina) pode reduzir o risco de desenvolver alguns tipos de câncer (CROSARA et al,2014).

Muitos tipos de células que são importantes na inflamação são encontrados em grandes quantidades no microambiente tumoral. Macrófagos associados ao tumor são importantes componentes do infiltrado da maioria dos tumores. Macrófagos associados ao tumor derivam de precursores de monócitos circulantes, os quais são atraídos para a região do tumor por quimiocinas. Diversas células tumorais também produzem citocinas chamadas fatores estimuladores de colônias que prolongam a sobrevivência destes macrófagos. Quando devidamente ativados, os macrófagos associados ao tumor podem matar as células tumorais ou provocar reações destrutivas de tecidos centradas sobre o endotélio vascular. No entanto, macrófagos associados ao tumor também podem produzir fatores de crescimento e fatores angiogênicos, bem como proteases que degradam a matriz extracelular. Assim, macrófagos associados ao tumor podem estimular a proliferação de células tumorais, promover angiogênese, e favorecer a invasão e metástase (GRIVENNIKOV et al, 2011).

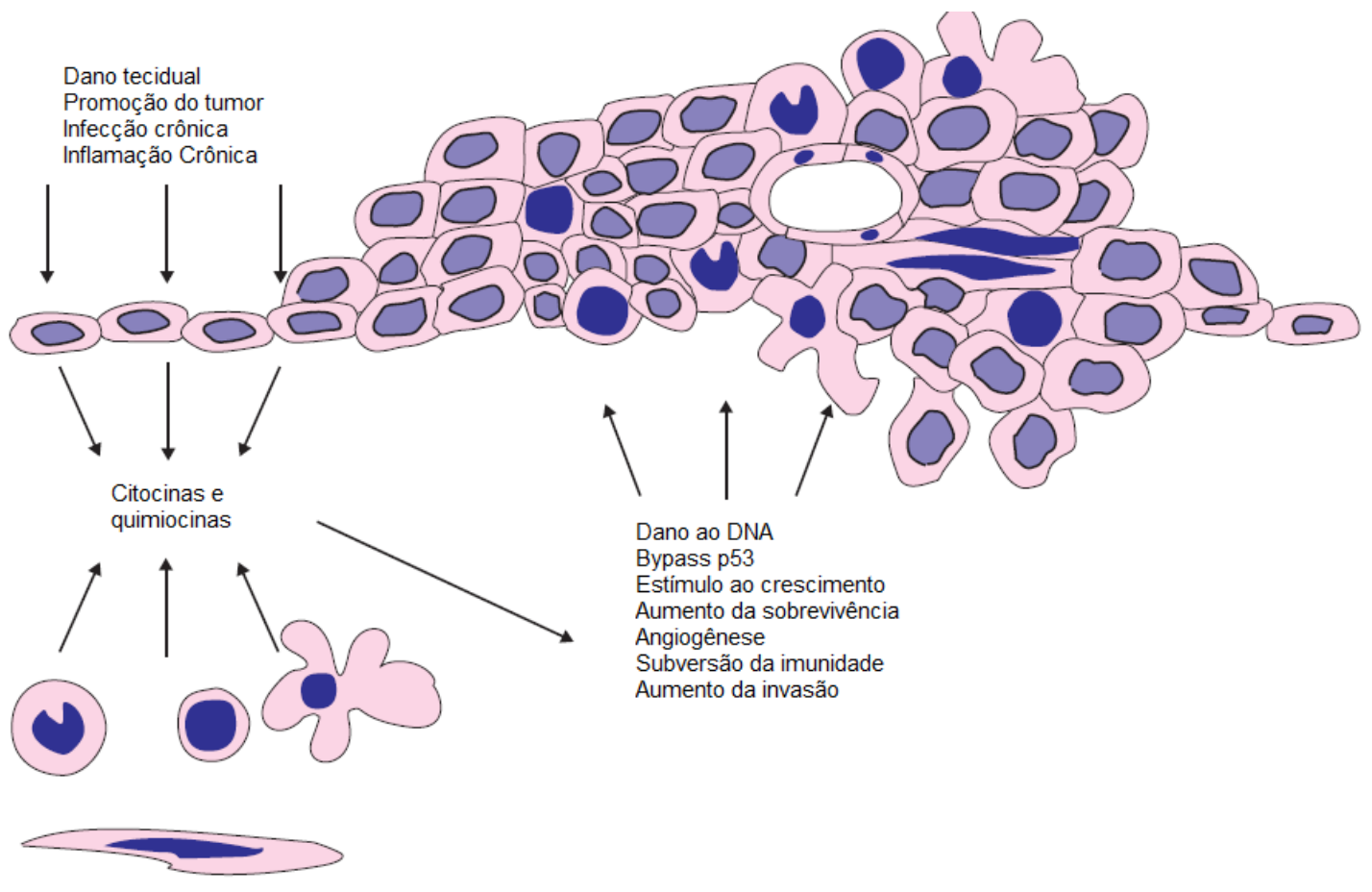

Figura 3. Correlação entre inflamação e câncer. Inflamação crônica, dano tecidual e infecção crônica podem estimular a produção de citocinas e quimiocinas que contribuem para o desenvolvimento de neoplasias malignas. Adaptado de BALKWILL; MANTOVANI, 2001. 


\subsection{Metabolismo Lipídico e Câncer}

Alguns ácidos graxos poli-insaturados tem efeitos profundos em células tumorais, exercendo citotoxidade e regulando genes relacionados a crescimento e metástase (JIANG et al, 2003). Alguns desses efeitos são exercidos diretamente por ácidos graxos, enquanto outros são exercidos por metabólitos derivados dos ácidos graxos. Lipoxigenases e ciclooxigenases são mediadores chaves do metabolismo de ácido araquidônico. Foi demonstrado que algumas dessas enzimas, notavelmente a ciclooxigenase $2(\mathrm{COX}-2)$ e a 12-lipoxigenase tem uma importância significativa no câncer. A via das lipoxigenases produz uma vasta gama de eicosanóides, incluindo HETE, lipotoxinas, leucotrienos e HODEs. A conversão de ácido araquidônico em 12-HETE, promovida pela 12-lipoxigenase, tem um efeito estimulatório nas células tumorais elevando a expressão e secreção de catepsina B e aumentando a invasão e migração de células tumorais (HONN et al, 1994). Em células de câncer de mama, a 12HETE aumenta a proliferação e invasão por um mecanismo que envolve a indução da secreção de colagenase (LIU et al, 1996). Foi demonstrado em modelos animais, que a 12lipoxigenase e seus metabólitos aumentam a angiogênese no câncer de mama e no câncer de próstata (CONNOLLY et al, 1998). A transfecção de células de adenocarcinoma de mama MCF-7 com 12-lipoxigenase resultou na perda de dependência do estímulo por estrógeno e aquisição de estímulo por ácido linoléico e aumento do crescimento tumoral (LIU et al, 1996).

Foi reportado que a 15-lipoxigenase tem um efeito estimulatório em células de câncer de próstata (KELAVKAR et al, 2001), e os ativadores da 5-lipoxigenase podem estimular a invasão e migração de células de tumor de mama, através da indução da produção de metaloproteases por essas células (TAYLOR et al, 2002). A 5-HETE, um metabólito da 5lipoxigenase, pode estimular o crescimento de células de tumor de mama e os inibidores desta enzima têm efeito oposto (AVIS et al, 2001). A inibição de 5-lipoxigenase pode reduzir a proliferação de células malignas e uma inibição inespecífica de lipoxigenases, feita com ácido nordihidroguiarético, promove uma redução na adesão de células de tumor de mama a células endoteliais (DAMTEW et al, 1997).

A via das ciclooxigenases do ácido araquidônico produz eicosanóides como PGE2, PGF2, TXA2 e TXB2. Estudos mostraram que inibidores de COX-2 reduzem significativamente o crescimento de tumores de mama (HOWE et al, 2002), e a indução da expressão de COX-2 pode induzir a transformação maligna (WOLFLE et al, 2000). Além disso, também foi reportado que a transformação maligna em células mamárias está associada 
com aumento da transcrição de COX-2 (SUBBARAMAIAH et al, 1996). Este aumento na expressão pode ser resultado de sinalização APC/wnt (HOWE et al, 1999). Alguns estudos analisaram células de tumor de mama humano e o tecido normal adjacente e observaram que as células tumorais apresentavam níveis mais elevados de COX-2 do que o tecido adjacente ao tumor (PARRET et al, 1997). A COX-2 também está envolvida no processo de angiogênese, pela influência que exerce na via do VEGF e PPAR $\gamma$ (LIANG et al, 2001). Estudos em humanos, analisando biópsias de mama e realizando acompanhamento das pacientes após a cirurgia, correlacionaram altos níveis de COX-2 e 5-LO com um pior prognóstico (JIANG et al, 2003).

\subsection{Corpúsculos lipídicos e câncer}

Corpúsculos lipídicos são organelas citoplasmáticas ricas em lipídios formadas por um centro de lipídio neutro cercado por uma monocamada de fosfolipídios com uma composição peculiar e exibindo uma diversa gama de proteínas associadas (BOZZA, MAGALHÃES, WELLER, 2009). Essa organela está presente em vários tipos celulares como fungos, bactérias, plantas e células de mamíferos (MURPHY, 2001). O mecanismo de formação exato dos corpúsculos lipídicos ainda não foi esclarecido completamente, porém já foram propostos diversos modelos hipotéticos. O modelo mais aceito, o do "brotamento", propõe que os corpúsculos lipídicos derivem da membrana do retículo endoplasmático (RE) após acúmulo de lipídios neutros entre as duas camadas da membrana do RE (MURPHY, 2001). Esta hipótese teve origem a partir de experimentos com microscopia de criofratura que mostraram deposição de ADRP (Proteína Relacionada à diferenciação de Adipócitos) em contato próximo com a membrana externa do RE.

A função principal dos corpúsculos lipídicos é o armazenamento de lipídios neutros e o estocagem de ácidos graxos e colesterol livre (MARTIN \& PARTON, 2005). A presença de enzimas envolvidas no metabolismo do colesterol e na síntese de ácidos graxos permite que lipídios estocados nessas organelas sejam hidrolisados e usados em seguida para $\beta$-oxidação, modificação de proteínas, síntese de membranas e geração de moléculas de sinalização (LIU et al, 2004). Alguns autores sugerem que a estocagem de citocinas produzidas por neutrófilos, macrófagos, eosinófilos, basófilos e mastócitos pode ser uma das funções dos corpúsculos lipídicos (BANDEIRA-MELO \& WELLER, 2005). Também já foi proposto que os corpúsculos lipídicos possam servir como estoque de proteínas, mantendo-as inativas quando não forem necessárias (WELTE, 2007). 
Os corpúsculos lipídicos são constitutivamente expressos em adipócitos e estão quase ausentes na maioria da células que não tem como função o armazenamento de lipídios. Apesar disso, quantidades elevadas de corpúsculos lipídicos tem sido observadas em condições patológicas, em células inflamatórias e cancerosas, tanto em condições experimentais quanto na clínica (BOZZA e VIOLA, 2010). Recentemente, muitos estudos têm investigado a relevância dos corpúsculos lipídicos na inflamação e na tumorigênese. Já foi demonstrado o aumento de corpúsculos em tamanho e número promovido por infecções, inflamação e neoplasia (MAYA-MONTEIRO et al, 2008). Está se tornando cada vez mais evidente que os corpúsculos lipídicos são sítios especializados envolvidos na compartimentalização e amplificação da síntese de eicosanóides. Os corpúsculos lipídicos foram descritos como sítios ricos em ácido araquidônico (AA) (WELLER \& DVORAK, 1985). Além disso, alguns estudos verificaram uma correlação entre a biogênese de corpúsculos lipídicos e a geração de eicosanóides derivados de lipoxigenase (LO) e ciclooxigenase (COX), respectivamente leucotrieno $\mathrm{B}_{4}\left(\mathrm{LTB}_{4}\right)$ e prostaglandina $\mathrm{E}_{2}\left(\mathrm{PGE}_{2}\right)$ (BOZZA et al, 1997; PACHECO et al, 2007).

\subsection{Receptores Nucleares e câncer}

Receptores nucleares $(\mathrm{RN})$ são proteínas que atuam na regulação da transcrição de genes alvos, como mediadores dos efeitos dos hormônios nas células. Eles agem como fatores de transcrição (FT) com as seguintes características: respondem à uma grande diversidade de sinais metabólicos ou reguladores hormonais de maneira direta, por meio de associação física com os mesmos; integram diversas vias de sinalização podendo ser, eles próprios, alvos de modificação pós-traducional; e regulam também transdução de sinal e a atividade de outras cascatas de sinalização (HODGKIN, 1999). Os RN são fundamentais para o desenvolvimento embrionário, para a diferenciação, metabolismo e morte celular. $\mathrm{O}$ desequilíbrio na sinalização dos RN pode promover doenças metabólicas, reprodutivas e proliferativas como diabetes, infertilidade e câncer (GRONEMEYER, 2004).

A superfamília dos $\mathrm{RN}$ é composta por 49 genes que codificam 75 proteínas distintas que possuem a função de regular a transcrição gênica no interior do núcleo celular (BOOKOUT, 2006).

Em células tumorais, a disfunção na expressão gênica altera o equilíbrio entre oncogenes e genes supressores tumorais, permitindo alteração no estado de diferenciação celular, evasão da apoptose e surgimento de metástase. Desse modo, a inibição de FTs 
oncogênicos ou a ativação de FTs supressores tumorais, em princípio, representariam uma alternativa terapêutica bastante efetiva para o tratamento do câncer (GRIVAS et al, 2011). No entanto FTs são notoriamente alvos ruins para drogas, com a notável exceção dos RNs, que compreendem uma superfamília de 48 FTs em humanos (EVANS, 2005), cujas ações são tipicamente dependentes de pequenos ligantes lipofílicos para os quais agonistas ou antagonistas já estão disponíveis ou podem ser sintetizados (CHEN, 2008). O fato de poderem se ligar a drogas e estarem envolvidos em várias vias relevantes para o câncer, faz com que RNs sejam importantes alvos para o tratamento do câncer. Além disso, a disfunção na sinalização de RNs exerce um papel central em diversos cânceres comuns, sendo o câncer de mama um exemplo típico (CONZEN, 2008).

No câncer de mama, tem sido demonstrado que dois RNs, Receptor de estrógeno alfa $(\mathrm{ER} \alpha)$ e receptor de progesterona (PR) desempenham um papel central na carcinogênese e na progressão deste tumor. Ambos os receptores promovem proliferação e sobrevivência das células tumorais em cerca de $60 \%$ a $70 \%$ de pacientes com esta patologia e são utilizados para classificar o câncer de mama e no prognóstico para resposta a medicamentos específicos (HARVEY et al, 1999).

O ER $\alpha$ é um dos principais alvos na terapia contra o câncer de mama, através de drogas que o inibem diretamente, como o tamoxifeno, ou através de inibidores de aromatase que bloqueiam a produção de seu ligante estrógeno. Embora o estudo dos RNs no câncer de mama esteja bastante limitado ao $\mathrm{ER} \alpha$ e $\mathrm{PR}$, pesquisas recentes revelaram a presença e potencial relevância de diversos outros RNs que podem servir como marcadores para diagnóstico e novos alvos terapêuticos (HUA et al., 2009; NI et al., 2011). Entre os RNs que tem sido mais bem estudados recentemente destaca-se o Receptor Ativado por Proliferador Peroxissomal (PPAR).

\subsection{PPAR - Receptor Ativado por Proliferador Peroxissomal}

O PPAR (do inglês peroxisome proliferator-activated receptor) é bastante estudado atualmente por sua associação a processos relacionados com metabolismo de lipídeos, obesidade, diabetes e resistência à insulina. O PPAR apresenta 3 isoformas diferentes, e desempenha um papel central na síntese e catabolismo de lipídeos, atuando essencialmente como sensor de ácidos graxos e seus metabólitos intermediários (YU, 2007).

As isoformas do PPAR apresentam distribuição tecidual e funções distintas. O PPAR $\alpha$ é expresso principalmente no fígado, porém também é encontrado no coração, nos rins, no 
tecido adiposo marrom, no músculo esquelético e no endotélio. O grupo de genes alvo do PPAR $\alpha$ é relativamente homogêneo, e compreende genes associados ao processo de catabolismo de lipídeos como a oxidação (peroxissomos e mitocôndrias), transcrição de fatores inflamatórios e transporte de ácidos graxos pela membrana e transporte de lipoproteínas (KERSTEN, 2000). Estes receptores tem como ligantes exógenos de uso clínico os fibratos, e como ligantes endógenos ácidos graxos livres (DESVERGNE,1999).

O PPAR $\delta$, também conhecido como $\beta$ ou $\beta / \delta$, ainda não tem seu papel bem estabelecido e foi a última isoforma a ser conhecida. O PPAR $\delta$ tem uma distribuição bem variada, podendo ser encontrado no tecido muscular, hepático, intestinal e adiposo. Apesar de ser a forma menos estudada, sabe-se que ele está relacionado à regulação de expressão de acetil-CoA sintetase 2 no cérebro, com atuação no metabolismo lipídico básico (RICOTE, 2007).

O PPAR $\gamma$ é a isoforma mais bem estudada. Esta isoforma é bastante expressa no endotélio, em células hematopoiéticas, células beta, intestino e no tecido adiposo branco e marrom (AKBIYIK, 2004). O PPAR $\gamma$ está ligado à conservação de energia e adipogênese, atuando diretamente na diferenciação de adipócitos. A maior parte dos genes regulados por esta isoforma é expressa no tecido adiposo, e influencia diretamente em vias lipogênicas incluindo a da acetil-CoA, proteína lipase (LPL), adipocyte fatty acid binding protein (AP2) e proteína transportadora de ácidos graxos (FATp) (WILLSON, 2001). Seus ligantes endógenos compreendem um derivado da prostaglandina $\mathrm{D}_{2}\left(\mathrm{PGD}_{2}\right)$, a 15 -desoxi- $\Delta 12,14$ prostaglandina J2 (15d-PGJ2), metabólitos do ácido linoleico e derivados das vias da 15 e 12/15 lipoxigenase (HUANG et al, 1999). As tiazolidinas (TZDs), como rosiglitazona e pioglitazona, são consideradas como principais agonistas entre os compostos sintéticos. Os AINEs, em altas concentrações também podem servir como agonistas para este subtipo de receptor (LEHMANN et al, 1997).

Diferente dos receptores de estrogênio ou glicocorticoides, os quais possuem um pequeno número de ligantes ao qual se ligam com alta afinidade, o receptor PPAR têm grandes cavidades hidrofóbicas que permitem a ligação de várias moléculas, porém com baixa afinidade. Alguns estudos mostram que o sítio de ligação deste receptor é bem amplo, permitindo a ligação de duas moléculas no mesmo bolso (ITOH et al, 2008).

A inflamação crônica é um fator de risco bem reconhecido para o desenvolvimento de câncer humano, e ao menos um terço de todos os cânceres têm sido associados à inflamação (MATKOWSKYJ, 2013). A ativação do PPAR $\gamma$ possui efeito anti-inflamatório em virtude da 
modulação negativa do NF-אB, resultando na inibição da produção de citocinas próinflamatórias como IL-8, e moléculas de adesão como ICAM-1 (REMELS et al, 2009). Dessa forma, o PPAR $\gamma$ pode atuar como uma ligação entre metabolismo lipídico e a resposta imune, por estimular alterações no perfil de mediadores inflamatórios e citocinas produzidos pelas células, a partir da sinalização de lipídios no ambiente (KOBAYASHI et al, 2005).

Orlando e colaboradores mostraram que a utilização de agonistas de PPAR $\gamma$ em conjunto com inibidores de COX-2 e 5-LO é capaz de promover a redução de tumores de mama em camundongos (ORLANDO et al, 2012). Alves e colaboradores sintetizaram diversos compostos a partir do ácido anacárdico, um lipídeo fenólico do líquido da casca da castanha de caju, e os caracterizaram como agonistas parciais de PPAR $\gamma$ (ALVES, 2015). Estes compostos serão alvo de investigação do presente trabalho.

\section{9 Ácido Anacárdico}

O ácido anacárdico é uma mistura de homólogos do ácido 2 - hidroxi - 6 alquilbenzóico, que são estruturalmente semelhantes ao ácido salicílico e à aspirina (SCHULTZ et al, 2010). O ácido anacárdico é comumente encontrado em plantas da família Anacardiaceae, e é um dos principais componentes do líquido da casca da castanha de caju (LCC) (SCHULTZ et al, 2010).

Diversas propriedades farmacológicas do ácido anacárdico foram descritas, tais como atividade anti-inflamatória, antimicrobiana, antioxidante e antitumoral (HEMSHEKHAR et al, 2011). A atividade anti-inflamatória do ácido anacárdico ocorre devido à regulação negativa de p300. A atividade de p300 e pCAF é interrompida de maneira não competitiva pelo ácido anacárdico e seus derivados, levando à inibição de histona acetiltransferase (HEMSHEKHAR et al, 2011).

O ácido anacárdico saturado é capaz de inibir a acetilação de p65 e de suprimir a

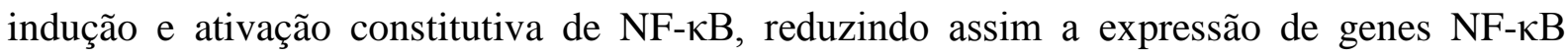

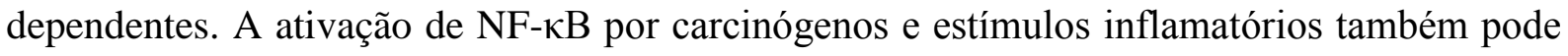
ser inibida pelo ácido anacárdico através da inibição da ativação de IKK, fosforilação e

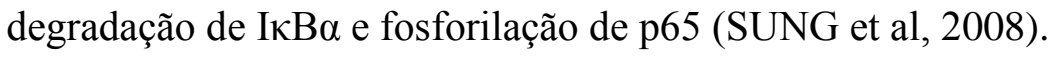

Foi demonstrado por Sung e colaboradores que o ácido anacárdico pode potencializar a apoptose induzida por TNF e agentes quimioterápicos, sugerindo assim um potencial antitumoral (SUNG et al, 2008). 


\subsection{Justificativa}

A alta prevalência do câncer de mama, bem como o grande impacto que ele causa na vida dos pacientes, caracterizam a importância que esta doença apresenta. Os principais tratamentos quimioterápicos antineoplásicos empregados atualmente são bastante tóxicos e causam reações adversas sérias. Assim, é importante a realização novos estudos visando o desenvolvimento de novos fármacos que tragam um maior benefício aos pacientes com menores efeitos colaterais. Além disso, a influência do metabolismo de lipídios no câncer é pouco conhecida, e os trabalhos que abordam este tema são raros. Portanto, considerando a grande influência que os ligantes de receptores nucleares possuem no controle da progressão de tumores, a descoberta e caracterização funcional de novas drogas agonistas de PPAR $\gamma$ em células de câncer de mama se torna importante, uma vez que pode auxiliar na descoberta de alternativas terapêuticas para o tratamento do carcinoma mamário.

Estudos que tratam do metabolismo lipídico em células tumorais podem levar a um melhor entendimento do papel de ligantes de receptores nucleares contra tumores. Sendo assim, esse projeto propõe a identificação e caracterização de novos agonistas parciais de PPAR $\gamma$, bem como a investigação dos mecanismos celulares e moleculares pelos quais eles agem sobre células do câncer de mama. Espera-se que seja possível um maior entendimento acerca das funções dos ligantes sintéticos de PPAR $\gamma$, de forma a elucidar o seu papel e os mecanismos celulares e moleculares envolvidos na tumorigênese.

\subsection{Objetivo}

\section{Objetivo geral}

Investigar a atividade biológica de drogas sintéticas derivadas do ácido anacárdico sobre células de tumor de mama invasivo e não invasivo.

\section{Objetivos Específicos}

Em células de câncer de mama tratadas ou não com derivados do ácido anacárdico:

- Investigar a atividade citotóxica das drogas;

- Analisar a viabilidade, proliferação, migração e ciclo celular;

- Analisar a expressão do mediador inflamatório 5-LO e a biogênese de corpúsculos lipídicos;

- Investigar a produção de espécies reativas de oxigênio e de nitrogênio; 
- Verificar a translocação de NFkB para o núcleo;

- Analisar a expressão de PPAR $\gamma$ celular;

- Caracterizar a ancoragem molecular (Docking) das drogas.

\section{MATERIAL E MÉTODOS}

\subsection{Reagentes e equipamentos}

Para a manutenção da cultura de células MCF-7 foi utilizado meio DMEM, SFB, Tripsina $0.25 \%$ em EDTA, todos da empresa GIBCO - Life Technologies Carlsbad, CA, EUA. Para manutenção de cultura de células MDA MB-231 foi utilizado meio Leibovitz L-15 da empresa Invitrogen.

As drogas foram sintetizadas no laboratório de Química da UnB (LADETER), e cedidas pelo prof. Luiz Romeiro.

Na análise de viabilidade foi utilizado MTT do fabricante Sigma- Aldrich, St.Louis, MO, EUA.

Os anticorpos primários utilizados foram anti PPAR $\gamma$ e anti NFאB p65 da marca Santa cruz Biotechnology, Inc.

O anticorpo secundário utilizado foi $\operatorname{IgG}$ de cabra anti coelho - Alexa Fluor 546 (A11010) da Invitrogen - Life Technologies Carlsbad, CA, EUA. Como marcador fluorescente para o núcleo utilizou-se DAPI, da Sigma- Aldrich, St.Louis, MO, EUA.

Os reagentes utilizados ao longo do trabalho foram: Iodeto de Propídeo da Molecular Probes - Life Technologies Carlsbad, CA, EUA; RNAse livre de DNAse, Anexina-V conjugada a FITC e CellTrace ${ }^{\circledR}$ CFSE Cell Proliferation kit, todos da Invitrogen - Life Technologies Carlsbad, CA, EUA; Colchicina e cristal violeta da Sigma- Aldrich, St.Louis, MO, EUA. Para leitura de absorbância do MTT , foi utilizado o equipamento Spectramax M3 e os dados foram analisados no programa SoftMax Pro 5.2, ambos da Molecular Devices, LLC, EUA.

\subsection{Cultivo Celular}

Para testar o efeito das drogas em tumor de mama não invasivo, células MCF-7, de adenocarcinoma mamário, foram cultivadas em meio DMEM suplementado com $10 \%$ de Soro fetal Bovino (SFB), com 100 U.I /mL de penicilina e $100 \mu \mathrm{g} / \mathrm{ml}$ estreptomicina e mantidas em estufa úmida a $37^{\circ} \mathrm{C}$ e $5 \%$ de $\mathrm{CO}_{2}$. Para testar o efeito das drogas em tumor de 
mama invasivo, células MDA MB-231 foram cultivadas em meio Leibovitz L15, suplementado com $10 \%$ de Soro fetal Bovino (SFB), com 100 U.I /mL de penicilina e 100 $\mu \mathrm{g} / \mathrm{ml}$ de estreptomicina e mantidas em estufa úmida a $37^{\circ} \mathrm{C}$.

Para testar o efeito das drogas em células não tumorais, foram utilizadas a linhagem MCF- 10 e células mononucleares do sangue periférico (PBMC). Para MCF-10, o meio usado foi o HAM'S F12 suplementado com 5\% de soro fetal equino, $1 \%$ de antibiótico, hidrocortisona $(0,5 \mu \mathrm{g} / \mathrm{ml})$, insulina $(10 \mathrm{ng} / \mathrm{ml})$ e fator de crescimento $(20 \mathrm{ng} / \mathrm{ml})$. Para o cultivo de PBMCs foi utilizado o meio RPMI 1640, suplementados com 10\% de SFB e 100 U.I $/ \mathrm{mL}$ de penicilina e $100 \mu \mathrm{g} / \mathrm{ml}$ de estreptomicina. Ambos os tipos celulares foram mantidos em estufa umidificada contendo $5 \%$ de $\mathrm{CO} 2$ a $37^{\circ} \mathrm{C}$.

\subsection{Viabilidade celular}

\subsubsection{MTT}

A viabilidade celular foi acessada pela produção de cristais após a adição do reagente MTT à cultura. No ensaio, $1 \times 10^{4}$ células foram plaqueadas em placa de 96 poços. Após os estímulos de $24 \mathrm{~h}$ e $48 \mathrm{~h}$, o sobrenadante foi substituído por solução de MTT 0,5mg/ml, diluído em meio de cultura DMEM, e foi feita incubação por $4 \mathrm{~h}$ na estufa a $37^{\circ} \mathrm{C}$. O sobrenadante foi descartado e os sais de formazan foram diluídos com $100 \mu \mathrm{l}$ de DMSO. A leitura da absorbância foi realizada no comprimento de onda de 570nm. Para os cálculos de viabilidade, a absorbância do grupo estimulado apenas com o veículo da drogas foi considerado como $100 \%$ de viabilidade e os outros grupos tiveram sua viabilidade calculada de forma proporcional.

\subsubsection{Morte Celular}

O tipo de morte celular promovido após estímulo com as drogas foi avaliado através de marcação com Anexina-V e Iodeto de Propídeo (PI). Foram plaqueadas $2 \times 10^{5}$ células por poço em placa de 24 poços. Depois dos tratamentos com as drogas, as células foram coletadas junto com os sobrenadantes para que as células mortas presentes no sobrenadante não fossem

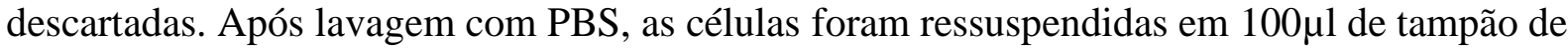


ligação de Anexina 1x (TLA) (HEPES10mM; $\mathrm{NaCl} 140 \mathrm{mM} \mathrm{CaCl}_{2} 2,5 \mathrm{mM}$ - ph 7.4) e $5 \mu \mathrm{l}$ de Anexina- V- FITC e incubadas por 15 minutos em temperatura ambiente ao abrigo de luz. Em seguida foram adicionados $400 \mu \mathrm{l}$ de TLA 1x contendo PI em uma concentração final de 2 $\mu \mathrm{g} / \mathrm{ml}$ e as amostras foram incubadas por 5 minutos a $4^{\circ} \mathrm{C}$. Depois disso, as células foram lavadas uma vez com TLA 1x, transportadas até o citômetro em recipiente com gelo, e lidas em citômetro de fluxo imediatamente. Foram adquiridos 10.000 eventos analisados pelas fluorescências nos canais FL1H e FL2H em escala logarítmica. Como controle experimental, foi induzida apoptose através do tratamento das células com $1 \mathrm{mM}$ de Monastrol, e as células necróticas foram obtidas com o aquecimento da amostra a $65^{\circ} \mathrm{C}$ por 15 minutos.

\subsection{Análise do ciclo celular com Iodeto de Propídeo}

Para analisar o ciclo celular, o conteúdo de DNA celular da população foi acessado através de marcação com Iodeto de Propídeo (PI). Esse marcador é um anelante de DNA, assim a quantidade de marcação presente na célula é proporcional à quantidade de DNA que a célula possui. Desse modo, em análise por citometria de fluxo, é possível quantificar as populações que possuem 2n de DNA, populações em G0/G1; com 4n de DNA, populações em G2/M; e as intermediárias, que estão na fase S. Ainda aquelas células cujo DNA está fragmentado apresentam uma quantificação de fluorescência abaixo do pico G0/G1, sendo então chamadas de pico sub-G1.

Logo com a fluorescência de PI, foi feita análise do ciclo celular e do nível de fragmentação nuclear pela quantificação da população sub-G1. Para isso foram plaqueadas $1 \times 10^{5}$ células por poço em uma placa de 24 poços, em $500 \mu 1$ de meio de cultivo e realizados os devidos tratamentos.

Com a coleta das células e seus sobrenadantes em tubos eppendorfs de $1.5 \mathrm{ml}$, essas foram centrifugadas por 5 minutos a $300 \mathrm{~g}$. O sobrenadante foi descartado e o pellet foi ressuspendido em $100 \mu \mathrm{l}$ de PBS. Foi adicionado $900 \mu \mathrm{l}$ de etanol 70\% gelado em cada tubo. As amostras foram mantidas a $4{ }^{\circ} \mathrm{C}$ por $2 \mathrm{~h}$. Posteriormente, os tubos foram centrifugados a 5000 r.p.m por 10 minutos. O sobrenadante foi descartado e adicionou-se $1 \mathrm{ml}$ de PBS. Após segunda centrifugação, as amostras foram ressuspendidas em solução contendo $0,1 \%$ de Triton X-100, $100 \mu \mathrm{g} / \mathrm{ml}$ de PI e $50 \mu \mathrm{g} / \mathrm{ml}$ de RNAse livre de DNAse em PBS, e mantidas a $37^{\circ} \mathrm{C}$ por 10 min protegidas de luz. Os tubos foram então centrifugados nas mesmas 
condições anteriores, o sobrenadante foi desprezado e as células ressuspendidas em PBS para aquisição.

Após a aquisição em citômetro de fluxo de 10.000 eventos totais no canal FL-2A em escala linear, as amostras foram analisadas em um gráfico de FL2-A por FL2-W para a exclusão de eventos em doublets. O pico sub-G1 foi analisado por meio da marcação de regiões e o ciclo celular acessado apenas na população de células vivas, em plataforma do próprio programa.

\subsection{Proliferacão Celular}

$\mathrm{Na}$ análise de proliferação das células, estas foram marcadas com o marcador CFSE, seguindo as recomendações do fabricante. Este marcador entra passivamente nas células viáveis e, depois de ser clivado por esterases citoplasmáticas se torna fluorescente. Assim, a cada divisão a célula divide seu conteúdo fluorescente com a célula-filha, de maneira que a cada geração há metade da fluorescência de geração anterior. Dessa forma é possível acompanhar a taxa de proliferação de células em cultura.

Para o ensaio, foram plaqueadas $2 \times 10^{5}$ células por poço em uma placa de 24 poços. Após adesão das células à placa, estas foram marcadas com solução contendo $10 \mu \mathrm{M}$ de CFSE diluído em meio de cultura por $10 \mathrm{~min}$ a $37^{\circ} \mathrm{C}$. Após esse período, a solução de CFSE foi substituída por meio de cultivo. Durante toda a cultura as células foram mantidas no escuro.

Como controle para células que não realizaram divisão, foi utilizado um tratamento com $10 \mu \mathrm{M}$ de colchicina.

Após o tempo de estímulo com as drogas (24h, 48h e 72h), as células foram removidas da placa, lavadas duas vezes com PBS e ressuspendidas. A leitura foi feita em citômetro de fluxo no canal FL1H com escala logarítmica, e foram adquiridos um total de 20.000 eventos por amostra.

Os dados foram analisados no software FlowJo, com a sobreposição da curva das células parentais tratadas com colchicina e das curvas das amostras de teste das drogas.

\subsection{Imunofluorescência}

Para análise da expressão de PPAR $\gamma$, e 5LO, bem como a determinação de sua localização celular por microscopia de fluorescência confocal, foram plaqueadas $5 \times 10^{4}$ células em placas de 24 poços, contendo lamínulas em seu interior. Após os tempos de 
estímulo, as células foram fixadas em formaldeído 3,7\% em temperatura ambiente por 15 minutos. Depois de 3 lavagens com PBS, foi utilizado 0,2\% de Triton $\mathrm{x}-100$ em PBS durante 20 minutos a temperatura ambiente para permeabilizar as células. Em seguida as células foram lavadas com PBS, e após isso foi adicionada solução de bloqueio (1\% leite em pó desnatado, 2,5\% BSA, 8\% SFB em PBS) por 20 minutos em temperatura ambiente.

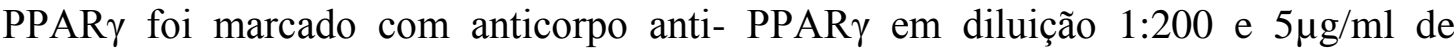
anticorpo secundário Alexa Fluor 546. 5LO foi marcado com anticorpo anti-5LO em diluição1:200 e 5 $\mu \mathrm{g} / \mathrm{ml}$ de anticorpo secundário Alexa Fluor 546. Para marcação do núcleo celular foi utilizado DAPI na concentração final de $300 \mathrm{nM}$. A montagem das lâminas foi feita com meio de montagem anti-decaimento da fluorescência.

\subsection{Análise da biogênese de corpúsculos lipídicos}

Para quantificação de corpúsculos lipídicos no citômetro de fluxo, foram plaqueadas $5 \times 10^{4}$ células em placas de 24 poços. As células foram tratadas com $10 \mu \mathrm{M}$ as drogas LDT11, LDT13, LDT380 e LDT383 por 24h. Células não tratadas foram utilizadas como controle. Após o tratamento as células foram lavadas com PBS e marcadas com a sonda Bodipy (Life Technologies) na diluição 1/300 em temperatura ambiente por 30 minutos. A análise foi realizada no citômetro FACSVerse (BD Biosciences). Os histogramas e médias de intensidade de fluorescência foram feitos com auxílio do software FlowJo (Tree Star Inc.).

\subsection{Migracão Celular - Wound Healing}

O ensaio de wound healing é muito utilizado para o estudo das características da migração celular. Assim, este experimento foi realizado com objetivo de analisar o efeito das drogas na migração da linhagem celular MDA-MB-231. Para a realização do experimento as células foram tripsinizadas, contadas e adicionadas em placas de 24 poços com lamínulas. Foram adicionadas $1 \times 10^{5}$ células em cada poço. Ao alcançarem confluência foi feita a ferida (risca) utilizando ponteiras de $20 \mu \mathrm{L}$. Os poços foram lavados com PBS 1x, e em seguida foi acrescentado meio de cultura. Posteriormente, foi acrescentado 10 $\mu \mathrm{M}$ de cada droga (LDT11, LDT13, LDT380 e LDT 383). No poço do controle foi acrescentado apenas meio de cultura. As células foram fotografadas nos tempos de 0 e 48 horas. A análise dos resultados foi feita 
com auxílio do software Image $\mathrm{J}$, a partir da medida da área do risco utlizando a fórmula (A inicial $-\mathrm{A}_{\text {final }} /\left(\mathrm{A}_{\text {inicial }}\right) \times 100=$ porcentagem de fechamento da ferida.

\subsection{Ensaio Clonogênico (Clonogenic Assay)}

O ensaio clonogênico é um ensaio de sobrevivência celular baseado na habilidade de uma única célula de crescer e formar uma colônia. Para a realização do experimento as células foram tripsinizadas, contadas, e em seguida foram adicionadas 150 células por poço, em uma placa de 6 poços. Posteriormente, para determinar os efeitos das drogas a longo prazo, as células foram estimuladas e permaneceram com o estímulo por 48 horas. Após este período o meio de cultura foi substituído por meio fresco sem estímulo, e esta substituição foi repetida a cada três dias até completar 14 dias de incubação. Depois disso, as células foram fixadas com solução de metanol e acetona 1:1, lavadas com PBS 1x uma vez e coradas com cristal violeta $0.5 \%$ overnight. Finalmente, foi feita contagem manual de colônias. Foram feitos 3 experimentos independentes e o resultado da contagem foi inserido no software Graph Pad Prism 5.0 para análise estatística.

\subsection{Análise da expressão de NFкB}

Para a análise da expressão de $\mathrm{NF \kappa B}$, as células foram permeabilizadas com Triton X100 (Sigma-Aldrich) 0,2\% por 20 minutos, bloqueadas com solução de PBS com 2\% de BSA por 30 minutos, incubadas com anticorpo primário na concentração de 1/300 durante aproximadamente $16 \mathrm{~h}$ e posteriormente com o anticorpo secundário anti-rabbit Alexa 546 (Life Technologies) por1h. O núcleo foi visualizado através de marcação com DAPI (Life Technologies) na concentração de 1/5000. As lâminas foram montadas em meio anti-fadding Prolong (Life Technologies) e as imagens foram obtidas no Microscópio Leica com aumento de $63 x$.

\subsection{Análise da producão de ROS}

Para análise da produção de ROS foram plaqueadas $5 \times 10^{4}$ células em placas de 24 poços. As células foram estimuladas por 3 horas e em seguida foi realizada marcação com a 
sonda 2'7' Diclorodihidrofluoresceína-diacetato (DFC-DA) que é permeável a membrana celular. A sonda não é fluorescente, porém na presença de ROS, o DFC-DA é oxidado no interior da célula e produz um composto fluorescente, a 2'7' - diclofluoresceína (DFC), que permanece no interior da célula.

Após o período de tratamento as células foram analisadas no citômetro de fluxo FACSVerse, no canal FL1 em escala logarítmica. Foram adquiridos 10.000 eventos de cada amostra. A análise dos dados foi realizada no software FlowJo com a sobreposição das curvas do controle não tratado e das amostras estimuladas com as drogas.

\subsection{Análise da expressão de PPAR}

Foi realizada extração de proteínas de células MDA MB-231 submetidas ao tratamento com $10 \mu \mathrm{M}$ as drogas LDT11, LDT13, LDT380, LDT383 e Rosiglitazona por 24h. Cerca de $20 \mu \mathrm{g}$ da suspensão protéica de cada amostra foi submetida à eletroforese em SDSPAGE (em gel com gradiente de acrilamida 4-12\%) e transferida para uma membrana de nitrocelulose em tampão de transferência $(100 \mathrm{ml}$ de $25 \mathrm{mM}$ Tris, $192 \mathrm{mMglicina}$ ph aproximadamente 8 quando dissolvidos em $80 \mathrm{~mL}$ de $\mathrm{H}_{2} \mathrm{O}$ MiliQ e $20 \mathrm{~mL}$ de metanol). A transferência foi feita a 15 Volts por 45 minutos em sistema semi-seco (Trans-Blot Semi Dry). Após a transferência, a membrana foi incubada por $1 \mathrm{~h}$ com solução bloqueadora de leite desnatado 5\% em TBST (50mM Tris, $\mathrm{pH} 7.4,150 \mathrm{mM} \mathrm{NaCl}, 0.05 \%$ Tween 20). Posteriormente, a membrana foi lavada com TBST, e incubada por apoximadamente $16 \mathrm{~h}$ com o anticorpo primário anti-PPARgamma (Santa Cruz Tech.) diluição 1:500, como controle de carregamento, foi utilizado o anticorpo monoclonal anti- $\beta$-actina (Sigma-Aldrich) na concentração 1: 50.000. Após esse tempo, as membranas foram lavadas com TBST, e as proteínas de interesse foram então identificadas pela incubação da membrana com anticorpos secundários anti-coelho e anti-camundongo (GE Life Sciences), conjugado a peroxidase (HRP) diluídos na hora do uso na concentração de 1: 5.000. Todos os anticorpos primários foram diluídos em solução de bloqueio, enquanto os secundários foram diluídos em TBST. A detecção foi feita através da utilização do kit ECL Prime Detection Reagent (GE Life Sciences) e a membrana reveladano ImageQuant LAS 4000 (GE Life Sciences). A quantificação das bandas foi realizada utilizando o software ImageJ. 


\subsection{Análise da produção de NO}

Para análise da produção de NO foram plaqueadas $5 \times 10^{4}$ células em placas de 24 poços. As células foram estimuladas por 24 horas com LDT11, LDT13, LDT380 e LDT383, e em seguida foi coletado o sobrenadante. Os sobrenadantes foram analisados quanto à produção de nitrito pela reação de Griess, como uma medida da produção de óxido nítrico. Para medir a produção de nitrito, alíquotas de $100 \mu \mathrm{L}$ das amostras a serem dosadas foram incubadas com $100 \mu \mathrm{L}$ dos reagentes $(50 \mu \mathrm{L}$ da solução de sulfanilamida $1 \%$ e $50 \mu \mathrm{L}$ de solução de $\mathrm{N}$-naphthyletilenediamine dihydrochloride $0,1 \%$ em 2,5\% de $\mathrm{H}_{3} \mathrm{PO}_{4}$ ) à temperatura ambiente por 10 minutos. A leitura foi realizada no SpectraMax em 570nm.

\subsection{Análise de ancoragem molecular (Docking)}

O docking foi realizado por nossos colaboradores do Laboratório de Biofísica da UnB. O programa utilizado para o docking foi o AutoDock Vina (TROTT; OLSON, 2010). Antes da corrida do docking, tanto a proteína PPAR $\gamma$ quanto o ligante foram preparados para a corrida com o auxílio da ferramenta MGLTools. Primeiramente foi realizada a preparação da proteína utilizada, através da retirada todas as moléculas de água da estrutura e adição de hidrogênios. Além disso, foi selecionada a área onde seria feita a procura ( grid box), a região de interação do ligante. Para a preparação dos ligantes, foi necessário determinar as ligações que são passíveis de sofrerem torsão. Em adição a isso, a carga dos ligantes foi detectada, e támbem cada átomo presente na molécula foi classificado. Os ligantes utilizados para o dockings foram os compostos LDT11, LDT13, LDT15, LDT29, LDT380 e LDT383 (tabela 1)

Dois tipos de ensaios de dockings foram feitos, primeiramente, foram realizados experimentos com o programa Autodock com a proteína rígida, ou seja, somente o ligante teve possibilidade de fazer a rotação dos ângulos torcionais entre seus átomos. $\mathrm{O}$ segundo tipo, por sua vez, permitiu a flexibilidade de algumas cadeias laterais de alguns aminoácidos da proteína (sendo esses aminoácidos os principais dentro do sítio ativo para o reconhecimento do ligante).

Devido ao fato da fenda onde se localiza o sítio ativo desta proteína ser bem grande é possível observar na literatura dois, e até três ligantes, interagindo em posições diferentes. Foram realizados ensaios de dockings ocupando duas posições no sítio ativo (região de interação próximo a ARG288 e próximo a TYR473). Essas posições serão ocupadas com o ligante 9-(S)-HODE que foi cristalizado com a proteína PPAR $\gamma$ (2VSR) (ITOH et al., 2008) 
Para ambos os ensaios de docking foram realizados experimentos com uma exhaustiveness fixa para cada tipo de docking, 256 para docking com a proteína rígida e 128 para o tipo onde as cadeias laterais dos principais resíduos aminoácidos responsáveis pela interação se encontram flexíveis. Os experimentos de docking foram realizados em duplicata.

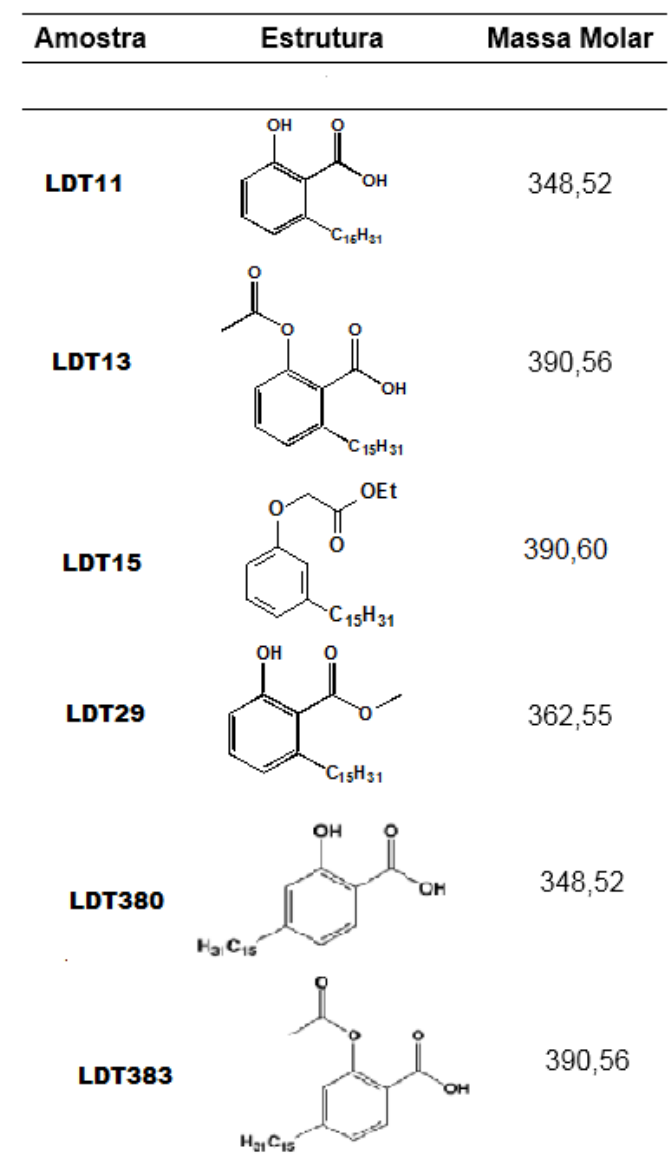

Tabela 1 - Estrutura e massa molar dos compostos derivados do ácido anacárdico 


\section{Resultados}

\subsection{Triagem dos compostos}

\subsubsection{Derivados do ácido anacárdico induzem reducão da viabilidade celular em MCF-7 e MDA-MB-231}

Como ainda não existem relatos dos efeitos dos compostos LDT em células de adenocarcinoma mamário, primeiramente se investigou se estes compostos afetariam a viabilidade das células MCF-7 e MDA-MB-231. Para isso foi utilizado o ensaio de MTT. O ensaio de MTT analisa quantitativamente a redução do sal de tetrazolium (MTT) pelo complexo enzimático piruvato desidrogenase presente nas mitocôndrias com a formação de um produto final de cristais de formazan que são mensurados em espectrofotômetro a 570nm. Esse ensaio é usado especificamente para a funcionalidade mitocondrial e viabilidade celular.

Inicialmente foi realizada uma triagem com os compostos LDT13, LDT15 e LDT 29. As células foram estimuladas com $100 \mathrm{nM}, 1 \mu \mathrm{M}$ e $10 \mu \mathrm{M}$ e o ensaio de MTT foi realizado após $24 \mathrm{~h}$ e $48 \mathrm{~h}$.

A linhagem celular MCF-7, quando tratada com $10 \mu \mathrm{M}$ de LDT 13, apresentou uma redução estatisticamente significativa da viabilidade celular em relação ao grupo controle (células não tratadas) após $24 \mathrm{~h}$ de estímulo com o composto (figura 4A). Após 48h de tratamento, os três compostos causaram redução estatisticamente significativa na viabilidade de células MCF-7, quando foi utilizada a concentração de $1 \mu \mathrm{M}$, porém apenas o LDT13 diminuiu de forma significativa a viabilidade das células quando a concentração utilizada foi $10 \mu \mathrm{M}$ (figura 4B). Não ocorreram alterações significativas quando as células foram tratadas com 100nM dos compostos.

Na linhagem celular MDA-MB-231, houve redução estatisticamente significativa na viabilidade após $24 \mathrm{~h}$ de tratamento com $1 \mu \mathrm{M}$ e $10 \mu \mathrm{M}$ de LDT13 em relação ao grupo controle (figura 5A). Quando as células foram tratadas com $10 \mu \mathrm{M}$ de cada composto por $48 \mathrm{~h}$, os três compostos testados (LDT13, LDT15 e LDT29) promoveram redução estatisticamente significativa da viabilidade celular de MDA-MB-231 quando comparados ao controle não estimulado. Após o tratamento com $1 \mu \mathrm{M}$ de cada composto por $48 \mathrm{~h}$, somente o LDT 13 reduziu de forma significativa a viabilidade celular (figura 5B). A concentração de 100nM não promoveu redução significativa na viabilidade celular. 
A.
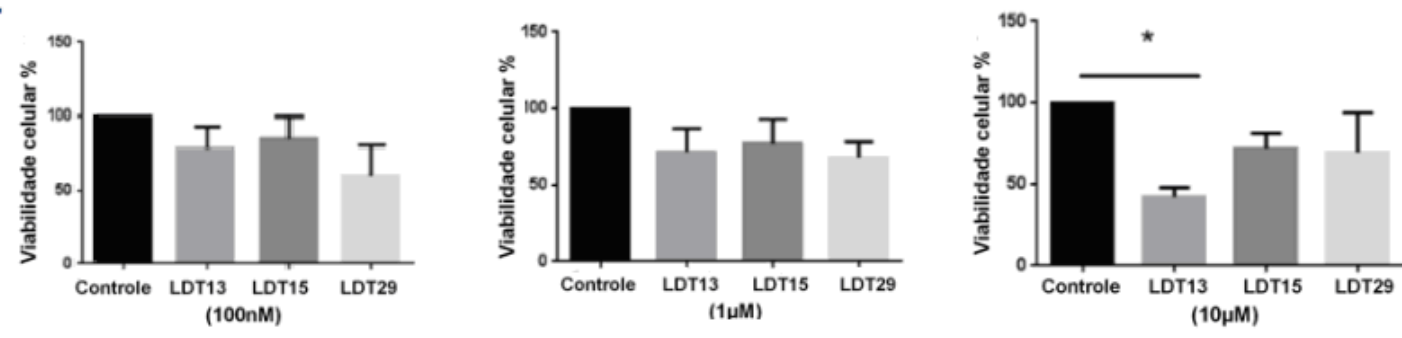

B.
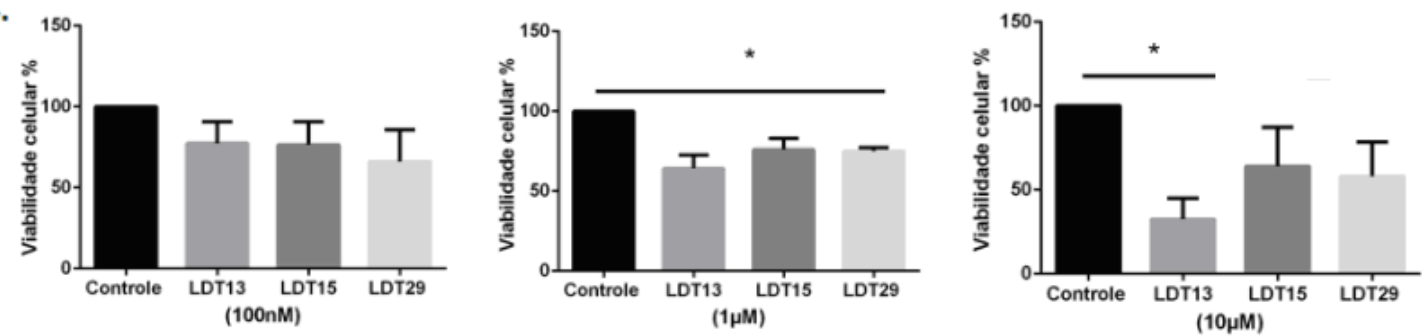

Figura 04 - Comparação das médias de viabilidade de MCF-7. (A) Células MCF7 expostas a $100 \mathrm{nM}, 1 \mu \mathrm{M}$ e $10 \mu \mathrm{M}$ de LDT13, LDT15 e LDT29 por 24h. (B) Células MCF7 expostas a 100nM, $1 \mu \mathrm{M}$ e $10 \mu \mathrm{M}$ de LDT13, LDT15 e LDT29 por 48h. Gráficos representativos de três repetições experimentais. O asterisco indica diferença significativa de viabilidade entre as células tratadas com as drogas e células não tratadas (controle) pelo teste one-way ANOVA (*) $\mathrm{P}<0.05$.

A.
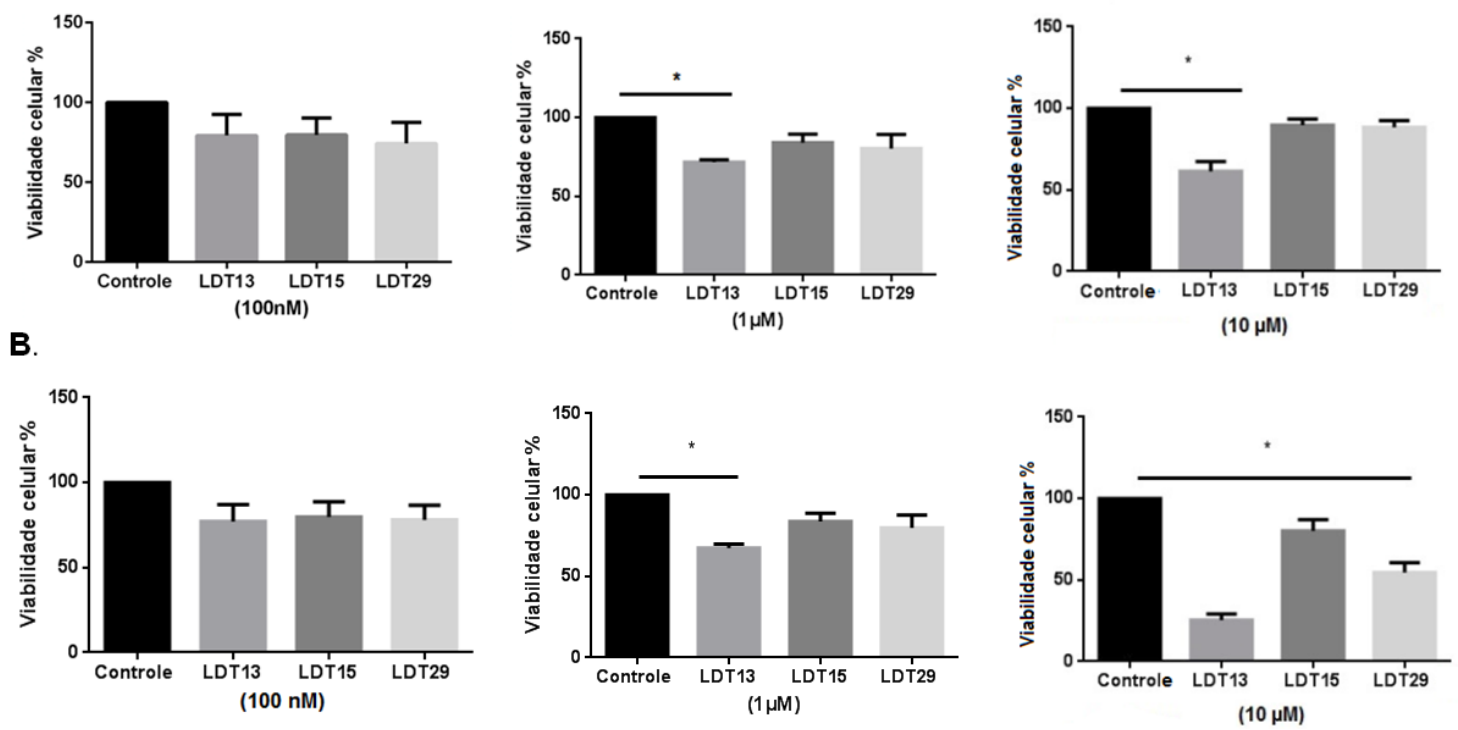

Figura 05 - Comparação das médias de viabilidade de MDA-MB-231. (A) Células MDA-MB-231 expostas a $100 \mathrm{nM}, 1 \mu \mathrm{M}$ e $10 \mu \mathrm{M}$ de LDT13, LDT15 e LDT29 por 24h. (B) Células MDA-MB-231 expostas a 100nM, 1 $\mu \mathrm{M}$ e $10 \mu \mathrm{M}$ de LDT13, LDT15 e LDT29 por 48h. Gráficos representativos de três repetições experimentais. O asterisco indica diferença significativa de viabilidade entre as células tratadas com as drogas e células não tratadas (controle) pelo teste one-way ANOVA $(*) \mathrm{P}<0.05$. 


\subsubsection{Derivados do ácido anacárdico não induzem redução da viabilidade celular em MCF-10 e PBMC}

Após verificar que os compostos LDT 13, LDT15 e LDT 29 afetam a viabilidade células tumorais, se investigou o efeito destes compostos na viabilidade de células não tumorais. Para isso foi realizado o ensaio de MTT em células MCF-10 e células mononucleares do sangue periférico (PBMCs) após o estímulo com $10 \mu \mathrm{M}$ de cada composto por $24 \mathrm{~h}$ e $48 \mathrm{~h}$. Nenhum dos compostos testados afetou de forma significativa a viabilidade das células MCF-10 (figura 6) e de PBMCs (figura 7).

A.

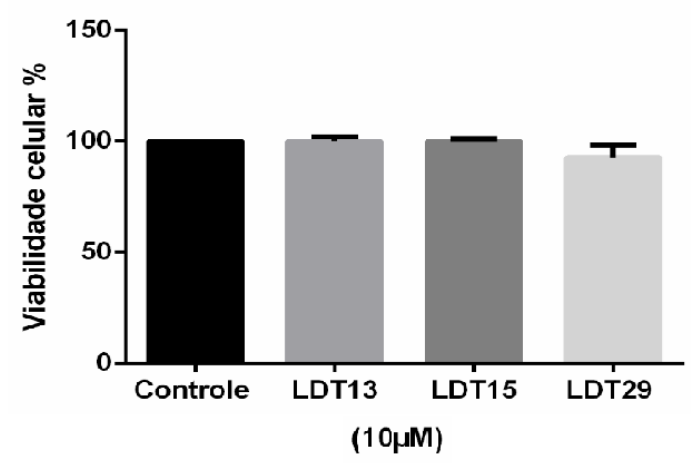

B.

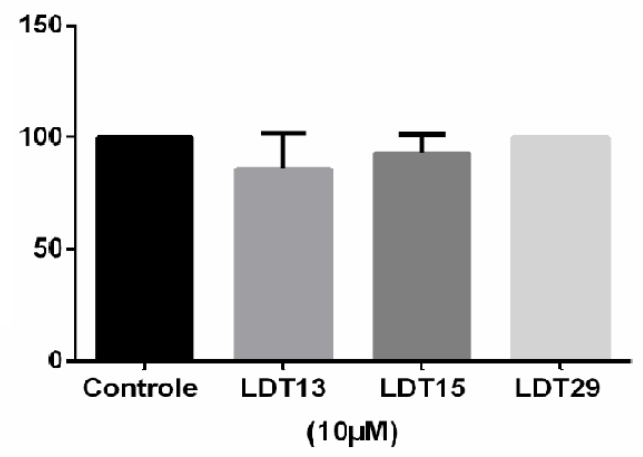

Figura 06 - Comparação das médias de viabilidade de MCF-10. (A) Células MCF-10 expostas a $10 \mu \mathrm{M}$ de LDT13, LDT15 e LDT29 por 24h. (B) Células MCF-10 expostas a $10 \mu \mathrm{M}$ de LDT13, LDT15 e LDT29 por $48 \mathrm{~h}$. Gráficos representativos de três repetições experimentais.

A.

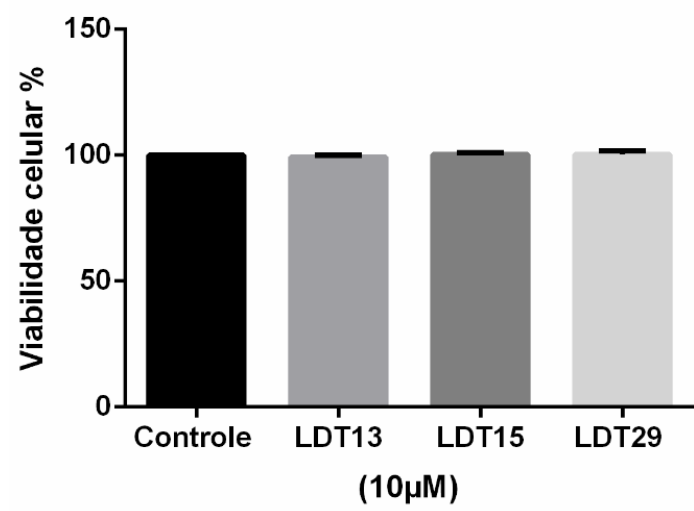

B.

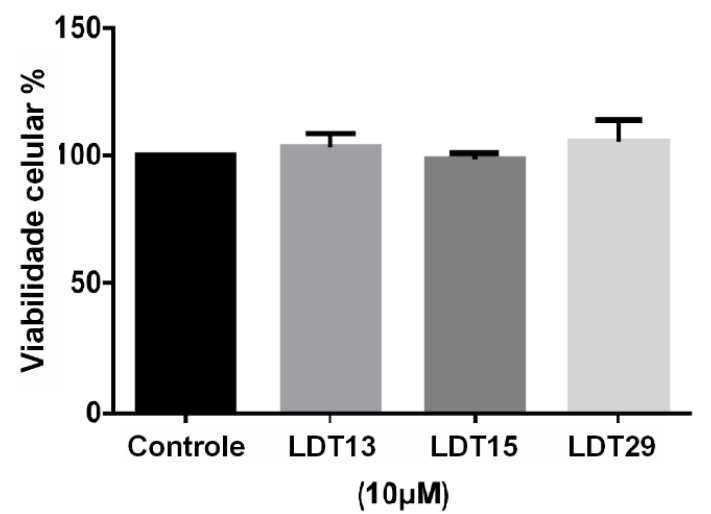

Figura 07 - Comparação das médias de viabilidade de PBMC. (A) Células mononucleares do sangue periférico expostas a $10 \mu \mathrm{M}$ de LDT13, LDT15 e LDT29 por 24h. (B) Células mononucleares do sangue periférico expostas a $10 \mu \mathrm{M}$ de LDT13, LDT15 e LDT29 por 48h. Gráficos representativos de três repetições experimentais. 


\subsubsection{Derivados do ácido anacárdico induzem reducão na proliferacão celular em MCF- 7 e MDA-MB-231}

Uma vez verificada a alteração na viabilidade de células tumorais de mama promovida pelos compostos, e a ausência de alterações significativas na viabilidade de células não tumorais, foi feita a análise de outro parâmetro importante que é a proliferação celular. Para isso foram realizados o ensaio clonogênico e marcação com CFSE. Para a análise da proliferação pelo marcador CFSE, células MCF-7 foram estimuladas com $10 \mu \mathrm{M}$ LDT13, LDT15 e LDT29 por 48h. Foram utilizadas células não tratadas como controle positivo para divisão, e células tratadas com $10 \mu \mathrm{M}$ de colchicina como controle negativo. A colchicina é um composto que pára a divisão das células durante a metáfase e, quando usada em ensaios com CFSE, nos possibilita observar a intensidade da fluorescência produzida caso as células não houvessem se dividido em cultura, sendo o pico de fluorescência inicial.

O gráfico de proliferação celular da MCF-7 mostra uma redução na proliferação das células tratadas com LDT13 e LDT29, enquanto as células tratadas com LDT 15 se apresentam semelhantes ao controle não tratado (figura 8).

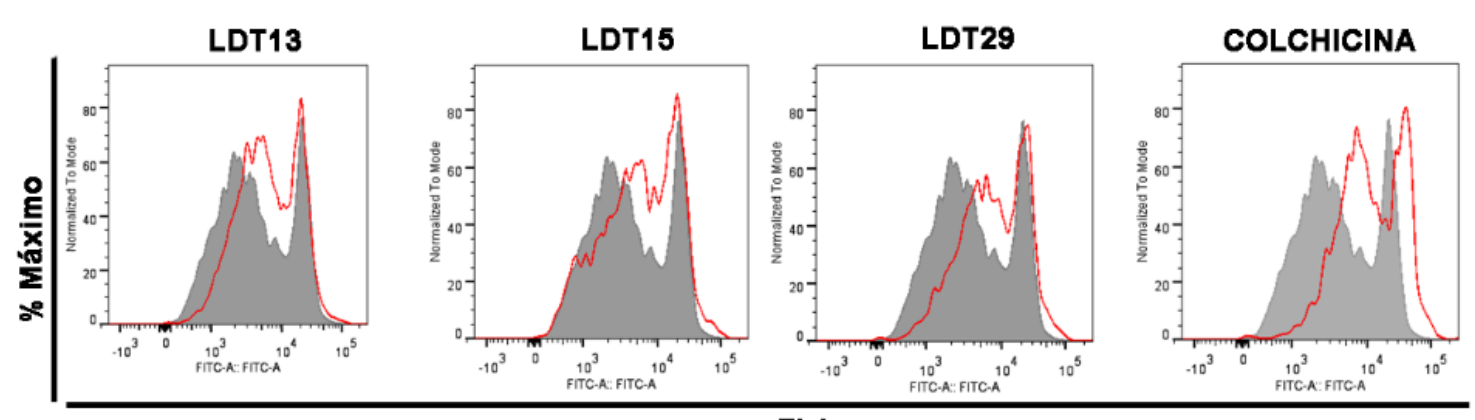

FL1

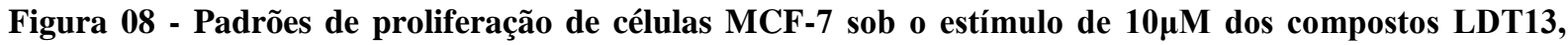
LDT15, LDT29 e colchicina. Células MCF-7 tratadas com os compostos LDT13, LDT15 e LDT29 por 48h seguida de marcação com CFSE. Nos histogramas o controle (células não tratadas) em cinza, e estimuladas com os respectivos tratamentos em vermelho. Imagem representativa de três experimentos. 
Após observar o efeito dos compostos na proliferação celular, o ensaio clonogênico foi realizado para investigar o efeito das drogas no potencial de formar colônias das células MCF-7 e MDA-MB-231. O ensaio clonogênico é um ensaio in vitro de sobrevivência celular baseado na habilidade de uma única célula de se dividir e formar uma colônia após um estímulo.

Todos os compostos promoveram redução significativa na formação de colônias tanto de MCF-7 quanto de MDA-MB-231, e o composto que causou a redução mais acentuada nas duas linhagens foi o LDT 13 (figura 9).

A.

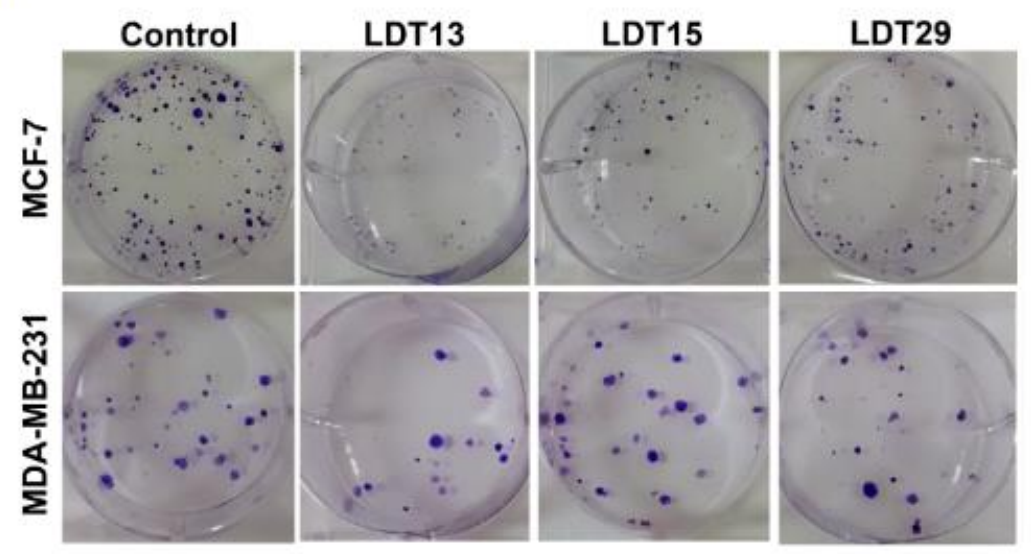

B.

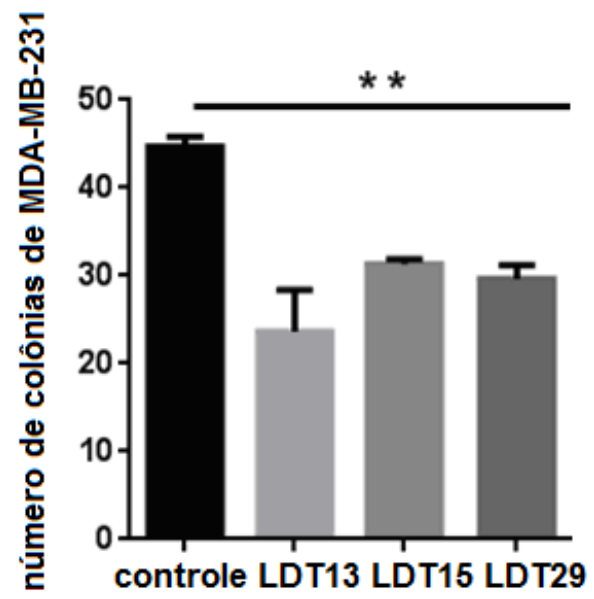

C.

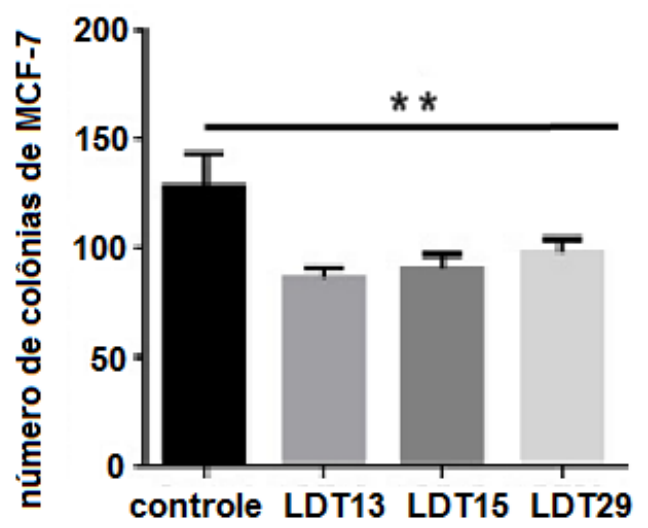

Figura 09 - Ensaio Clonogênico. (A) Imagem representativa da placa. (B) Gráfico de barras mostrando a quantificação das colônias de MDA-MB-231. (C) Gráfico de barras mostrando a quantificação das colônias de MCF-7. As células foram expostas a $10 \mu \mathrm{M}$ de LDT13, LDT15 e LDT29 por 48h e em seguida meio sem os compostos foi adicionado e substituído por meio fresco a cada 3 dias por 14 dias. Após esse período as colônias foram coradas com cristal violeta e contadas. Gráficos representativos de três repetições experimentais. O asterisco indica diferença significativa no número de colônias entre as células tratadas com as drogas e células não tratadas (controle) pelo teste one-way ANOVA $(* *) \mathrm{P}<0.01$. 
Após observar os resultados da triagem inicial das drogas, composta pelos ensaios de viabilidade e proliferação, decidiu-se continuar as análises com o composto que apresentou os melhores resultados (LDT13), e incluir novas drogas semelhantes a este composto nas análises que seriam feitas posteriormente. Quando o LDT13 é metabolizado, ele dá origem ao composto LDT11. Por este motivo resolveu-se investigar os efeitos do LDT11 em células de tumor de mama, e adicionar também o LDT380 (isômero do LDT11) e o LDT383 (isômero do LDT13) nas análises feitas após a triagem inicial dos compostos.

\subsection{Análise dos compostos da série LDT13}

\subsubsection{Os compostos LDT11, LDT13, LDT380 e LDT383 induzem reducão da viabilidade celular em MDA-MB-231}

Quantificou-se inicialmente a viabilidade de células de adenocarcinoma mamário invasivo por meio de MTT na presença dos compostos LDT11, LDT13, LDT380 e LDT383 em diferentes concentrações. A concentração mais alta utilizada foi de $20 \mu \mathrm{M}$, e a partir dessa concentração foram feitas 7 diluições que reduziam em $50 \%$ a concentração inicial dos compostos.

Com exceção do composto LDT380 nas concentrações $312 \mathrm{nM}$ e $156 \mathrm{nM}$, todos os outros compostos em todas as concentrações testadas foram capazes de reduzir a viabilidade celular de MDA-MB-231 de maneira significativa quando comparado com o controle de células não tratadas (figura 10). O composto que reduziu a viabilidade celular de forma mais acentuada foi o LDT13, e as concentrações de $2.5 \mu \mathrm{M}$ e $1.25 \mu \mathrm{M}$ deste composto foram as mais efetivas na redução da viabilidade das células (figura 10B). Apesar de ter sido possível observar redução significativa na viabilidade celular, esta redução não foi dose dependente. A relação dose-efeito observada após o tratamento das células com os compostos LDT11, LDT13, LDT380 e LDT383 foi não linear.

Foi realizado o ensaio de MTT em PBMCs para avaliar o efeito dos compostos em células não tumorais, e não houve alteração significativa na viabilidade de células tratadas 
com os compostos supracitados quando comparadas com o controle de células que não receberam estímulo.

A.

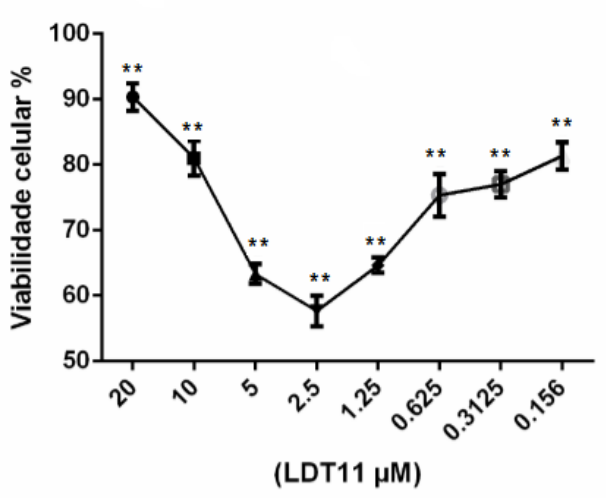

c.

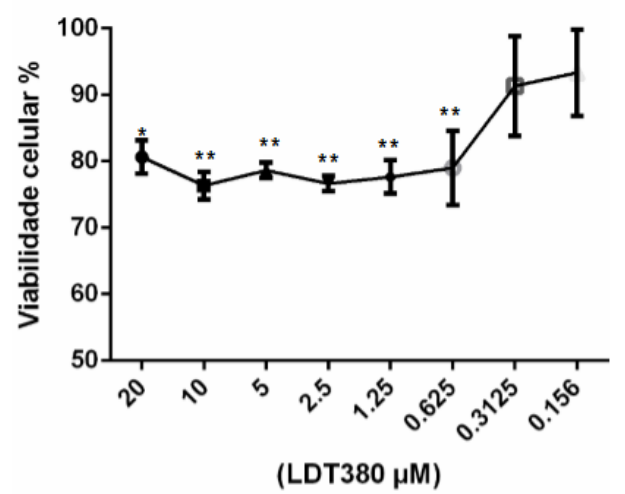

B.

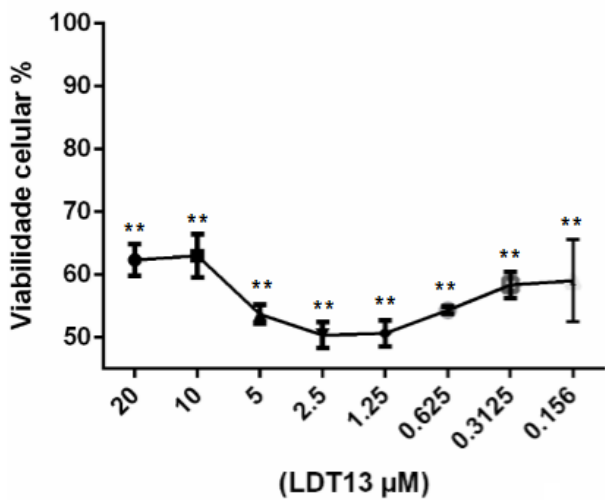

D.

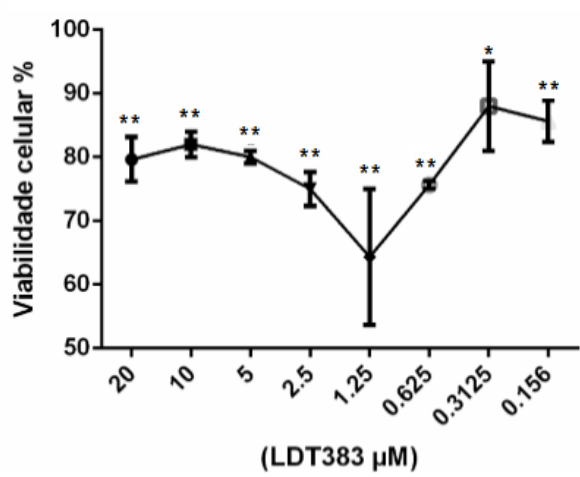

Figura 10 - Redução na viabilidade celular de MDA-MB-231 pela estimulação com LDT11, LDT13, LDT380, LDT383. (A) Células MDA-MB-231 expostas a $10 \mu \mathrm{M}$ de LDT11 por 48h. (B) Células MDA-MB231 expostas a $10 \mu \mathrm{M}$ de LDT13 por 48h. (C) Células MDA-MB-231 expostas a $10 \mu \mathrm{M}$ de LDT380 por 48h. (D) Células MDA-MB-231 expostas a $10 \mu \mathrm{M}$ de LDT383 por 48h. A porcentagem de viabilidade foi calculada considerando células não estimuladas como $100 \%$ de viabilidade. Gráficos representativos de três repetições experimentais. $\mathrm{O}$ asterisco indica diferença significativa de viabilidade entre as células tratadas com as drogas e células não tratadas (controle) pelo teste one-way ANOVA com pós teste Dunnett $\left(^{*}\right) \mathrm{P}<0.05$. (**) $\mathrm{P}<0.01$.

\subsubsection{Os compostos LDT11, LDT13, LDT380 e LDT383 promovem reducão na proliferaç̃o celular em MDA-MB-231}

Uma vez verificada a alteração na viabilidade celular promovida pelos compostos, foi feito o ensaio clonogênico para investigar o efeito dos compostos na proliferação de células de adenocarcinoma de mama invasivo. Células MDA-MB-231 foram expostas a $10 \mu \mathrm{M}$ de LDT11, LDT13, LDT380 e LDT383 por $48 \mathrm{~h}$ e em seguida meio sem os compostos foi 
adicionado e substituído por meio fresco a cada 3 dias por 14 dias. Após este período foi possível observar um crescimento de colônias significativamente reduzido nas células tratadas com LDT11, LDT13, LDT380 e LDT383 quando comparadas com o controle não tratado. Dentre os tratamentos, o que promoveu a redução mais acentuada foi o LDT13. O controle apresentou um número médio de 79,6 colônias $\pm 6,8$, enquanto o tratamento com LDT13 fez com que este número médio de colônias caísse para 9,6 7,2. As células tratadas com LDT11 formaram em média 40,3 colônias $\pm 1,5$ e as células tratadas com LDT380 e LDT 383 formaram um número médio de $44 \pm 22$ e $54 \pm 6,2$ respectivamente.

A.

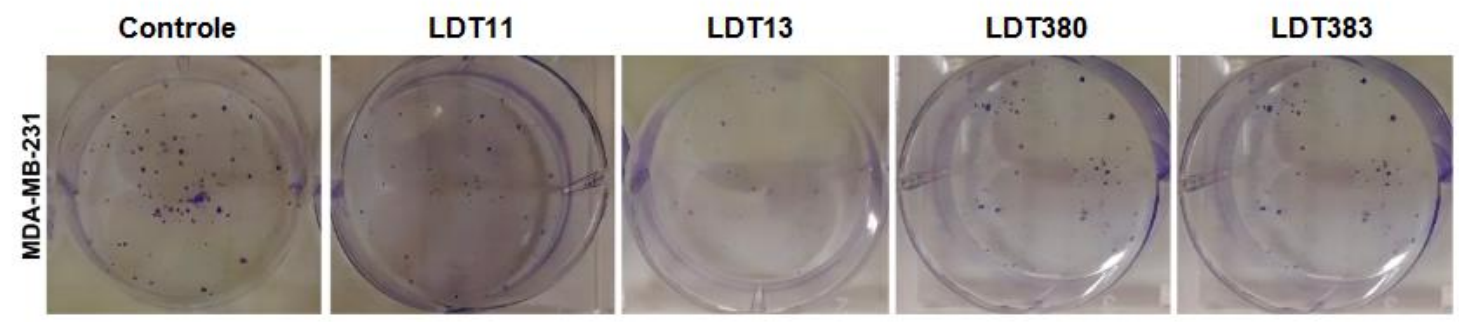

B.

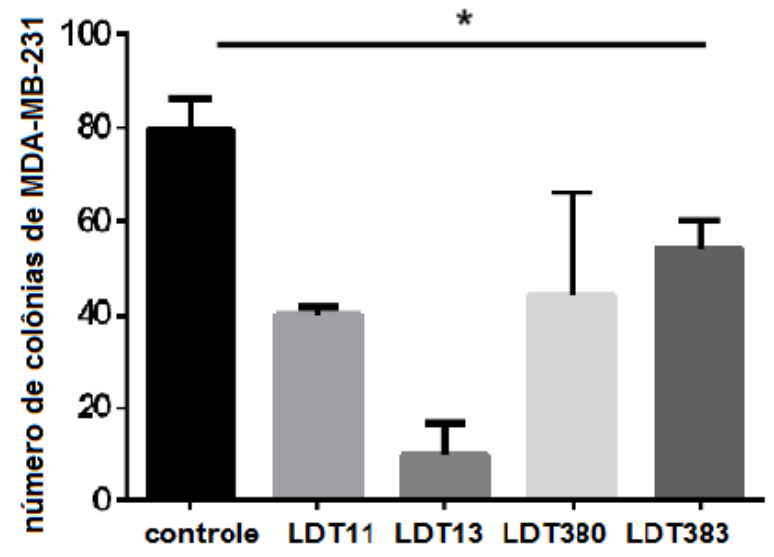

Figura 11 - Ensaio Clonogênico. (A) Imagem representativa da placa. (B) Gráfico de barras mostrando a quantificação das colônias de MDA-MB-231. As células foram expostas a $10 \mu \mathrm{M}$ de LDT11, LDT13, LDT380 e LDT383 por $48 \mathrm{~h}$ e em seguida meio sem os compostos foi adicionado e substituído por meio fresco a cada 3 dias por 14 dias. Após esse período as colônias foram coradas com cristal violeta e contadas. Gráficos representativos de três repetições experimentais. $\mathrm{O}$ asterisco indica diferença significativa de viabilidade entre as células tratadas com as drogas e células não tratadas (controle) pelo teste one-way ANOVA $(*) \mathrm{P}<0.05$. 


\subsubsection{Os compostos LDT11, LDT13, LDT380 e LDT383 promovem alteracão na}

morfologia de células MDA-MB-231

Para investigar o efeito dos compostos LDT11, LDT13 e seus respectivos isômeros na morfologia de células de adenocarcinoma de mama invasivo, células MDA-MB-231 foram estimuladas com $10 \mu \mathrm{M}$ dos compostos citados anteriormente. Foram feitas imagens no microscópio Zeiss Axiophot de fase invertida 24h e 48h após o tratamento.

Foi possível observar alterações morfológicas, tais como arredondamento das células, redução no tamanho e células não aderidas. Essas alterações foram mais evidentes nas células estimuladas com LDT11 e LDT13 (figura 12) 

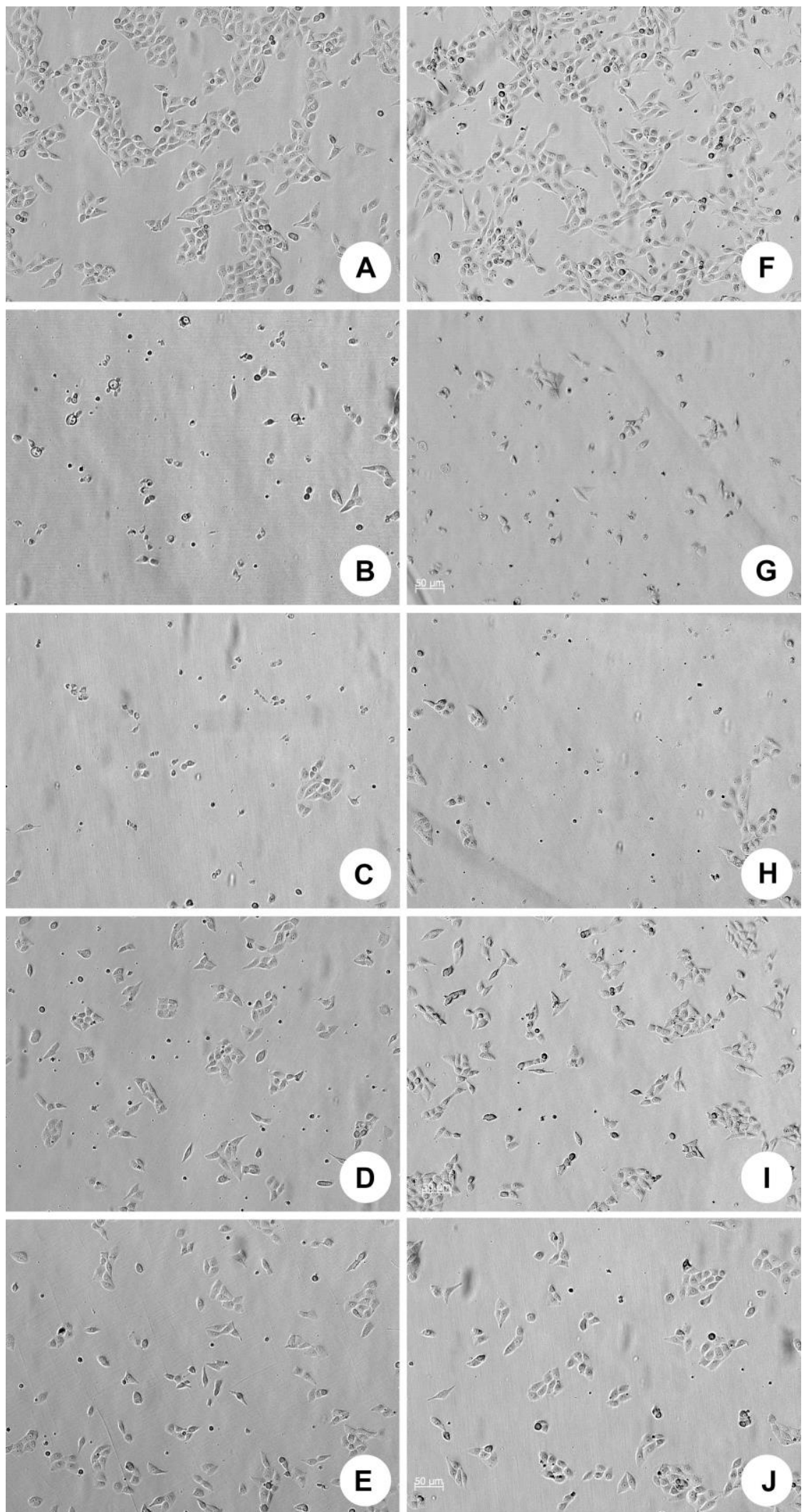

Figura 12 - Imagem de microscopia de contraste de fase de células MDA-MB-231. As células foram expostas a $10 \mu \mathrm{M}$ de LDT11, LDT13, LDT380 e LDT383 por 24h e 48h. Após este período foram feitas imagens no microscópio Zeiss Axiophot de fase invertida com aumento de 5x. (A) Células não tratadas após 24h. (B) Células tratadas com LDT11 por 24h. (C) Células tratadas com LDT13 por 24h. (D) Células tratadas com LDT380 por 24h. (E) Células tratadas com LDT383 por 24h. (F) Células não tratadas após 48h. (G) Células tratadas com LDT11 por 48h. (H) Células tratadas com LDT13 por 48h. (I) Células tratadas com LDT380 por 48h. (J) Células tratadas com LDT13 por 48h. (I) Células tratadas com LDT383 por 48h. 


\subsubsection{Os compostos LDT11, LDT13, LDT380 e LDT383 induzem apoptose em MDA-}

$\underline{\text { MB-231 }}$

Por ser um evento precoce no desencadeamento da morte celular, a exposição de fosfatidilserina, indicada com Anexina- $\mathrm{V}$, foi analisada apenas no tempo de $24 \mathrm{~h}$. As células foram estimuladas com $5 \mu \mathrm{M}$ e $10 \mu \mathrm{M}$ dos compostos LDT11, LDT13, LDT380 e LDT383. Este teste mostrou que ocorreu um aumento significativo no percentual de células em apoptose com a utilização de $5 \mu \mathrm{M}$ de todas as drogas (figura 13B). Também foi possível observar que com o aumento da concentração dos compostos utilizada houve uma elevação no percentual de apoptose. Quando as células foram estimuladas com $10 \mu \mathrm{M}$ houve um aumento significativo no percentual de apoptose das células tratadas com LDT380 e LDT383 (figura $13 \mathrm{C})$. 
A.

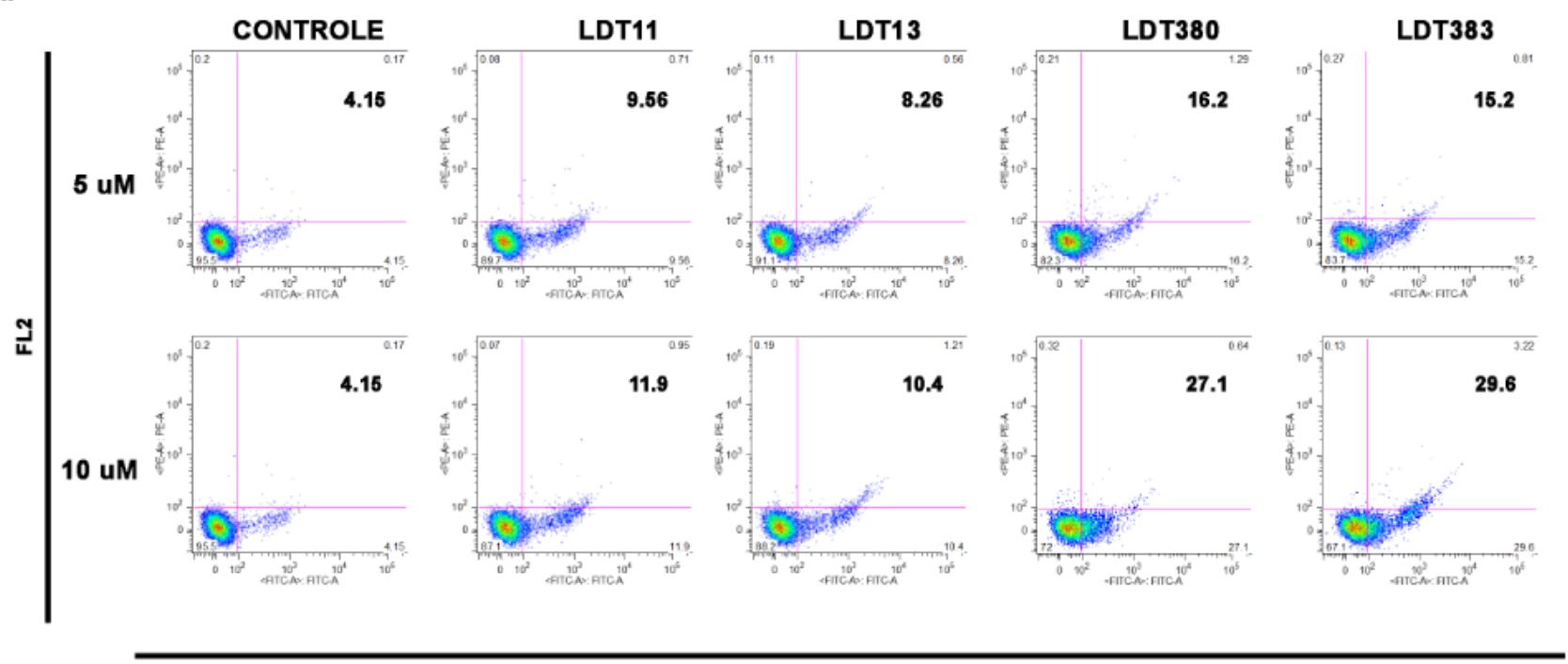

FL1

B.

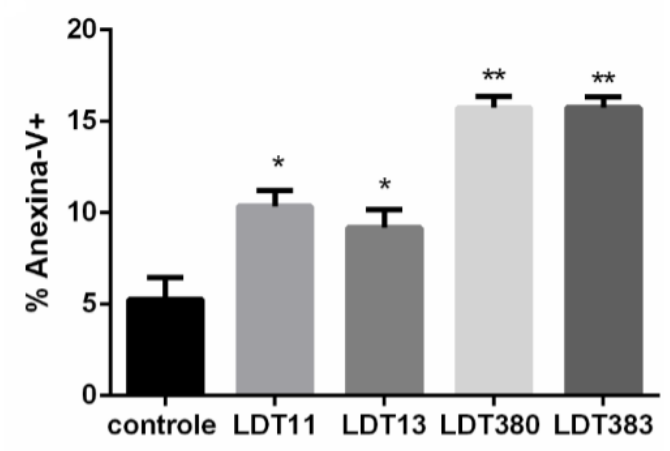

$(5 \mu \mathrm{M})$ c.

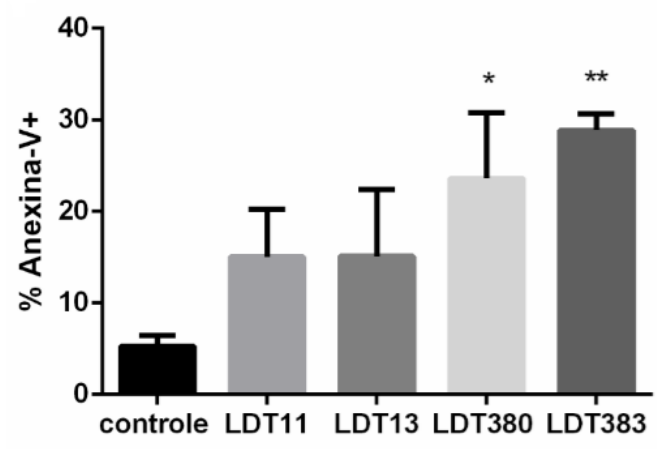

$(10 \mu \mathrm{M})$

Figura 13 - Morte celular de células MDA-MB-231. Após tratamento com $10 \mu \mathrm{M}$ dos compostos LDT11, LDT13, LDT380 e LDT383 por 24h foi realizada marcação com Anexina-V e PI. (A) Dot plots representativos de três experimentos independentes. Valores em negrito representam a porcentagem de células na região Anexina-V+. (B) Gráfico de barras mostrando a quantificação de células apoptóticas após estímulo com $10 \mu \mathrm{M}$ de cada composto. (C) Gráfico de barras mostrando a quantificação de células apoptóticas após estímulo com 5 $\mu \mathrm{M}$ de cada composto. $\mathrm{O}$ asterisco indica diferença significativa entre as células tratadas com as drogas e células não tratadas (controle) pelo teste one-way ANOVA com pós teste Dunnett $\left(^{*}\right) \mathrm{P}<0.05$. (**) $\mathrm{P}<0.01$. 


\subsubsection{Os compostos LDT11, LDT13, LDT380 e LDT383 induzem reducão da migracão celular em MDA-MB-231}

Para verificação do efeito dos compostos LDT11, LDT13, LDT380 e LDT383 na migração de células MDA-MB-231 foi realizado experimento de migração celular em triplicata pelo modelo de wound healing.

Após as células atingirem confluência, foi feita a "ferida" (risca) e logo em seguida a lamínula que aparece na figura 14A foi fixada e corada. Com exceção do controle, as demais células foram estimuladas com $10 \mu \mathrm{M}$ de cada composto, e após $48 \mathrm{~h}$ foram fixadas e coradas com cristal violeta.

Neste ensaio foi possível evidenciar uma redução significativa na migração das células após $48 \mathrm{~h}$ de estímulo com todos os compostos testados, quando comparamos com células não tratadas (figura 14G). A inibição da migração foi mais acentuada nas células tratadas com LDT11 (figura 14C) e LDT13 (figura 14E). A redução promovida pelos isômeros não foi tão exacerbada, mas ainda assim foi significativa.

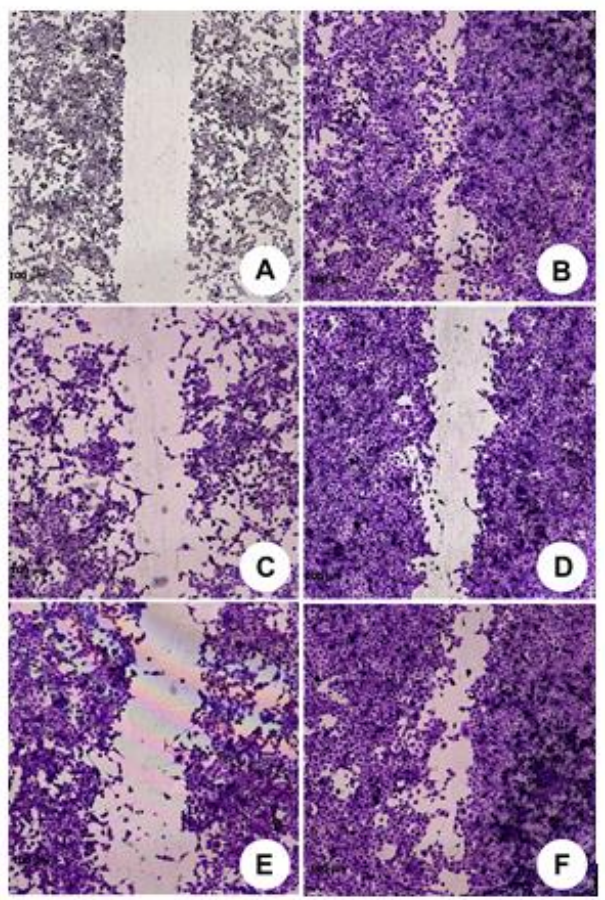

G.

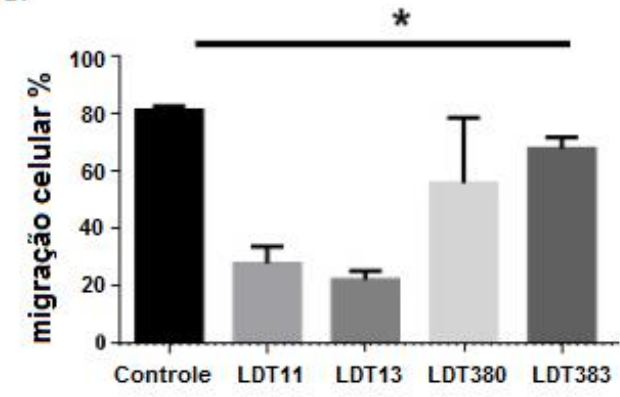

Figura 14 - Ensaio de wound healing (A) células não tratadas $0 \mathrm{~h}$. (B) células não tratadas 48h. (C) células tratadas com $10 \mu \mathrm{M}$ de LDT11 por $48 \mathrm{~h}$. (D) células tratadas com $10 \mu \mathrm{M}$ de LDT380 por 48h. (E) Células tratadas com $10 \mu \mathrm{M}$ de LDT13 por 48h. (F) células tratadas com $10 \mu \mathrm{M}$ de LDT383 por 48h. (G) Gráfico de barras mostrando a quantificação da migração de células MDA-MB-231 após 48h de estímulo. O asterisco indica diferença significativa de migração entre as células tratadas com as drogas e células não tratadas (controle) pelo teste one-way ANOVA (*) $\mathrm{P}<0.05$. 


\subsubsection{Alteracões no ciclo celular em MDA-MB-231 promovidas pelos compostos LDT11, LDT13, LDT380 e LDT383}

Uma das principais características do câncer, e que determina em grande parte seu aspecto nocivo, é a grande capacidade de proliferação das células tumorais. Para compreender se haveria efeito no processo de divisão celular após o uso de agonistas parciais do PPAR $\gamma$, foi utilizado como parâmetro o perfil de ciclo celular das células MDA-MB-231 não tratadas.

$\mathrm{Na}$ análise do ciclo celular, a MDA-MB-231 apresentou alterações no ponto de análise de 24h, com diminuição significativa da fase S nas células tratadas com LDT11 e LDT383 e aumento da fase G0/G1 promovido pelo composto LDT11 (figura 15). Isso demonstra que as células tratadas com esse composto ficam retidas na fase G0/G1 do ciclo celular, reduzindo de forma significativa a frequência de progressão à fase $S$ quando comparada à população de células não submetidas ao tratamento.

A.

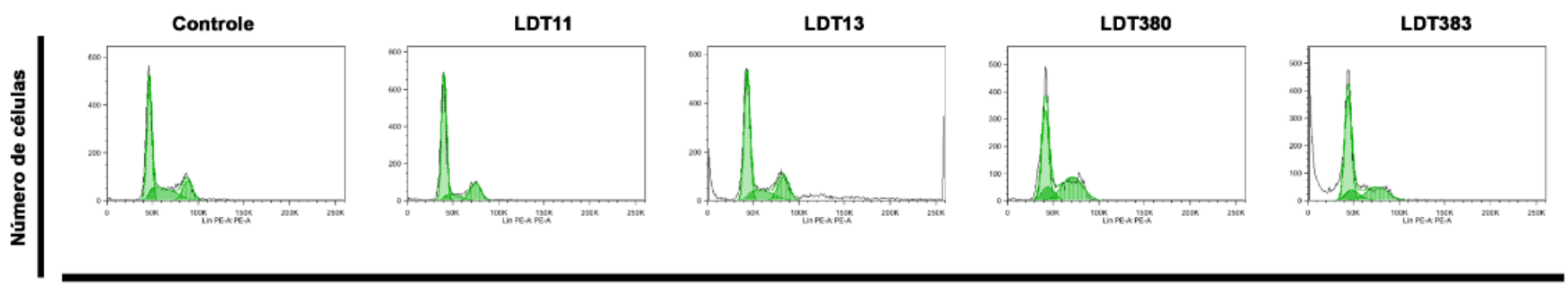

FL2A

B.

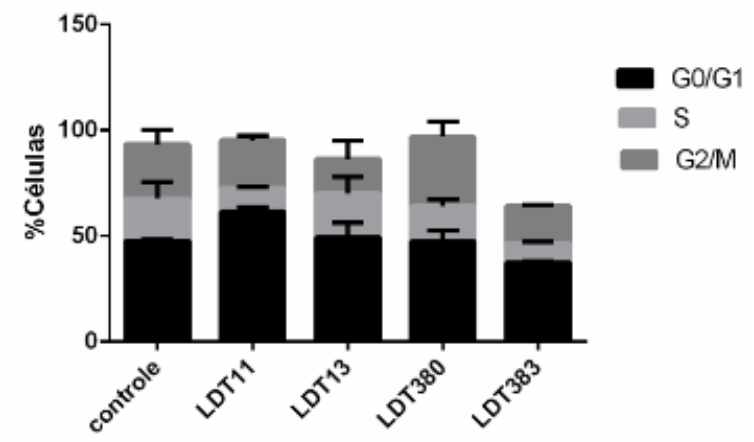

Figura 15 - Variação na distribuição de células em diferentes etapas do ciclo celular. (A) Células MDAMB-231 foram tratadas com $10 \mu \mathrm{M}$ de LDT11, LDT13, LDT380 e LDT383 por 24h, e em seguida marcadas com PI para análise do ciclo celular por citometria de fluxo. A determinação do ciclo celular foi realizada em plataforma específica do software FlowJo. Na figura, histogramas de análise de ciclo celular representativos de três experimentos independentes. (B) Gráfico mostrando a quantificação da distribuição de células em diferentes pontos do ciclo celular. Cada coluna representa a média com desvio padrão de três experimentos 


\subsubsection{Os compostos LDT11, LDT13, LDT380 e LDT383 induzem aumento na fragmentacão nuclear em MDA-MB-231}

A fragmentação nuclear é um dos eventos que acontece durante o processo de apoptose. Para analisar a fragmentação nuclear foi realizada por marcação com PI. Essa marcação permite quantificar por citometria de fluxo a fluorescência emitida pela intercalação com o DNA, que é variável em cada fase do ciclo celular. Desse modo é possível analisar as células que perderam DNA por fragmentação. Após a permeabilização da membrana, os fragmentos menores que 182 bp (pares de base) de DNA, saem da célula e o resultado é uma população de células com quantidade de DNA reduzida que é identificada no pico denominado sub G0/G1.

Após a quantificação do pico sub G0/G1, observou-se um aumento significativo da fragmentação nuclear promovido pelo tratamento com os compostos LDT11, LDT13, LDT380 e LDT383 em comparação com o controle (figura 16). O composto que promoveu o percentual mais elevado de fragmentação nuclear foi o LDT383, que gerou uma fragmentação cerca de três vezes maior que os demais compostos testados.

A.

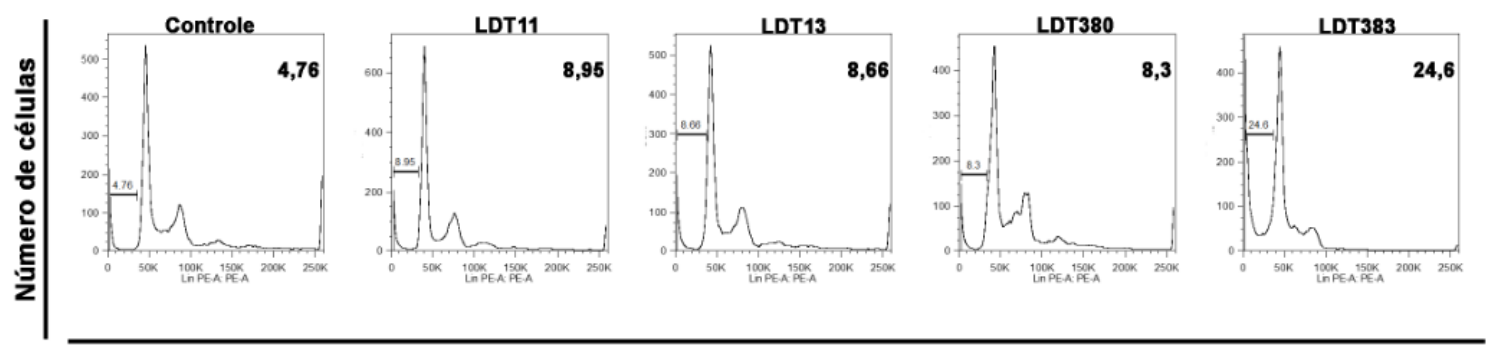

FL2A

B.

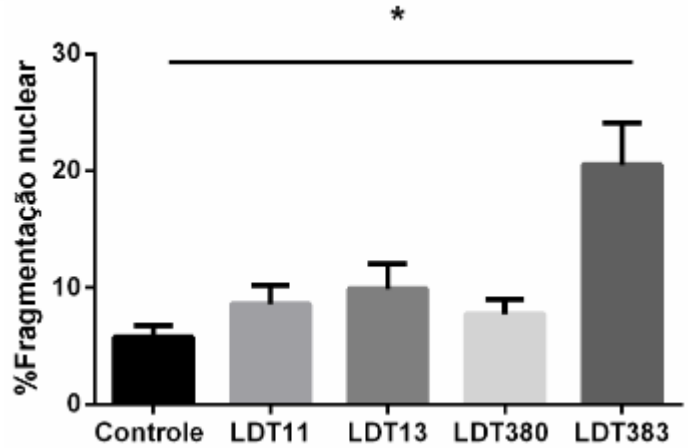

Figura 16 - Indução de fragmentação nuclear após estimulação com LDT11, LDT13, LDT380 e LDT383. As células foram estimuladas com $10 \mu \mathrm{M}$ das drogas citadas anteriormente e analisadas quanto ao seu conteúdo de DNA por citometria de fluxo. (A) Histogramas representativos da leitura de PI (FL2A) de três experimentos independentes. Valores em negrito indicam a porcentagem de células em sub G1. (B) Gráfico de barras mostrando a quantificação da fragmentação nuclear em MDA-MB-231. O asterisco indica diferença significativa de fragmentação nuclear entre as células tratadas com as drogas e células não tratadas (controle) pelo teste oneway ANOVA (*) $\mathrm{P}<0.05$. 


\subsubsection{LDT 13 promove o aumento da producão de ROS em MDA-MB-231}

Para avaliar a produção de ROS em MDA-MB-231, as células foram estimuladas com com $10 \mu \mathrm{M}$ de LDT11, LDT13, LDT380 e LDT383 por 3h. Em seguida foi realizada marcação com a sonda DFC-DA, e posteriormente leitura no citômetro de fluxo.

Cada tratamento foi plotado em histograma e comparado à células não estimuladas representadas pela curva de cor cinza. A menadiona gera um aumento na produção de ROS, e por isso foi utilizada como controle positivo.

Dentre os diferentes tratamentos, somente o composto LDT13 aumentou de forma significativa a produção de ROS (figura 17). O isômero do LDT13 também elevou levemente a produção de ROS, mas este aumento não foi significativo.

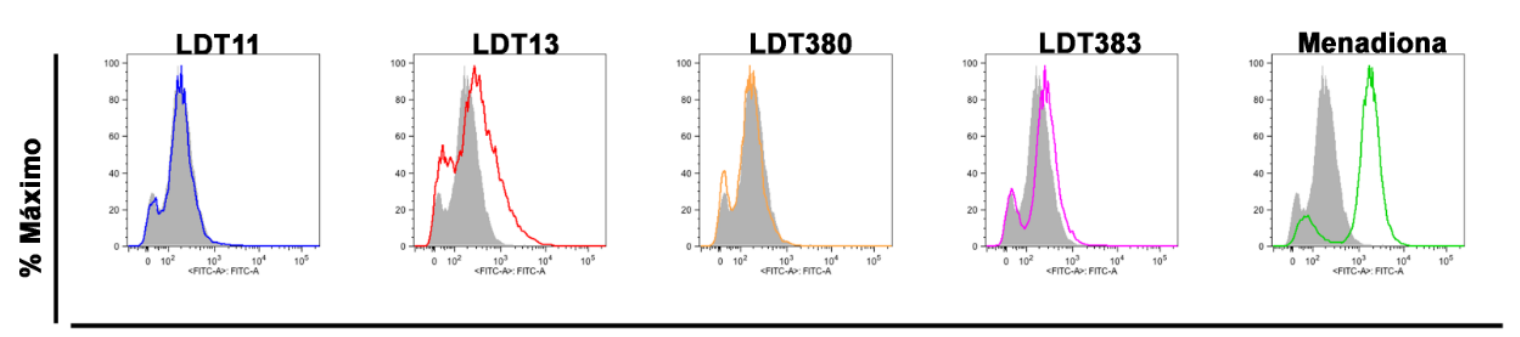

Produção intracelular de ROS

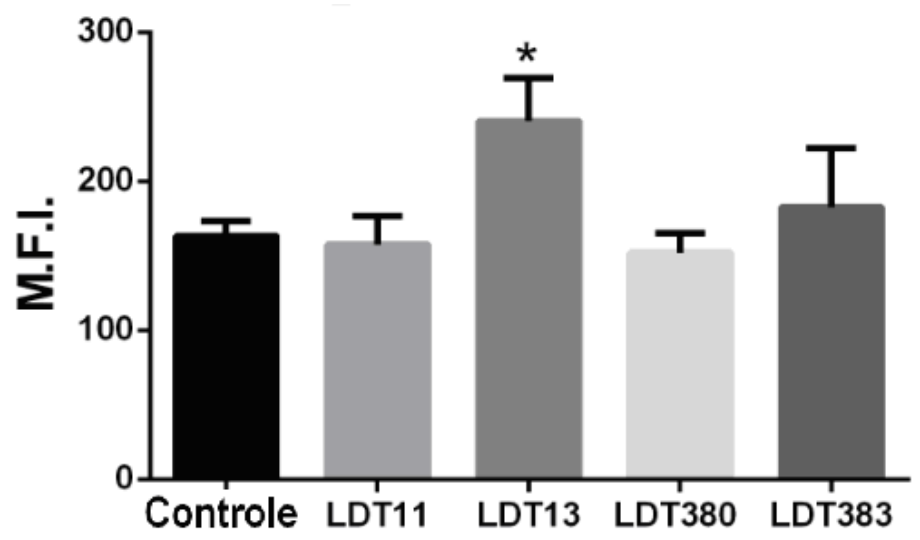

Figura 17 - Análise das alterações da quantidade de produção de espécies reativas de oxigênio em células MDA-MB-231. (A) Tratamento com $10 \mu \mathrm{M}$ de LDT11, LDT13, LDT380 e LDT383 por 3h. Os histogramas mostram a curva do controle (células não estimuladas) em cinza e dos respectivos tratamentos. Cada imagem é representativa de três experimentos. (B) Quantificação da produção de espécies reativas de oxigênio. O gráfico mostra a intensidade de fluorescência relativa de cada amostra. Cada coluna representa a média, com desvio padrão de três experimentos. $\mathrm{O}$ asterisco indica diferença significativa na produção de ROS entre as células tratadas com LDT13 e células não tratadas (controle) pelo teste one-way ANOVA (*) $\mathrm{P}<0.05$. 


\subsubsection{Os compostos LDT11, LDT13, LDT380 e LDT383 induzem aumento na biogênese de corpúsculos lipídicos}

Para verificar os efeitos dos compostos LDT11, LDT13, LDT380 e LDT383 em células de adenocarcinoma de mama, as células foram estimuladas com $10 \mu \mathrm{M}$ de cada composto e em seguida marcadas com a sonda Bodipy.

Cada tratamento foi plotado em histograma e comparado à células não estimuladas representadas pela curva de cor cinza. Todos os compostos aumentaram a biogênese de corpúsculos lipídicos de maneira significativa (figura18).
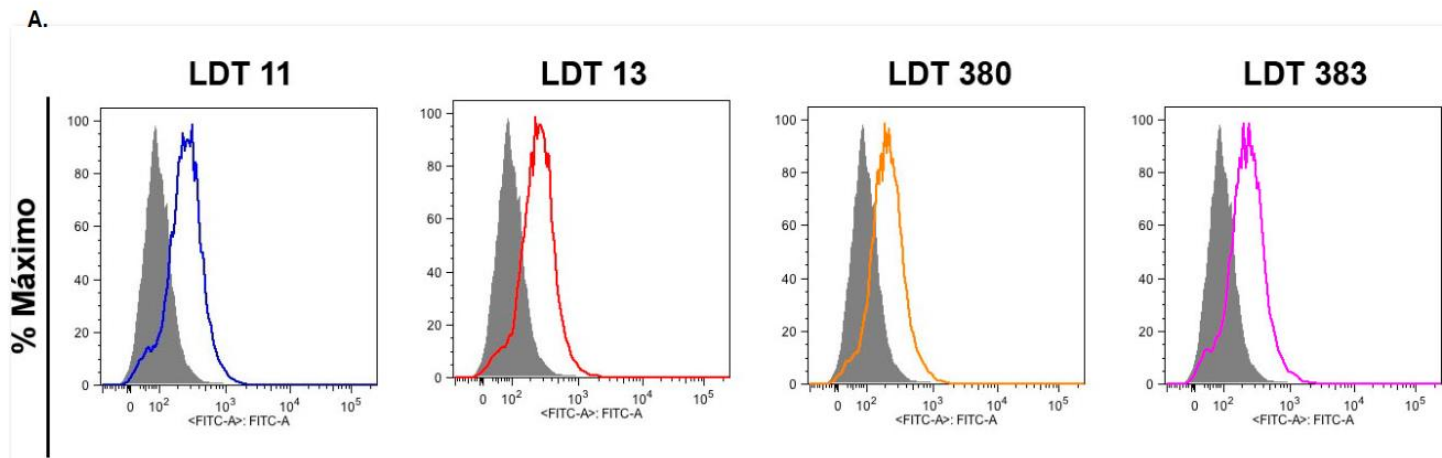

BODIPY

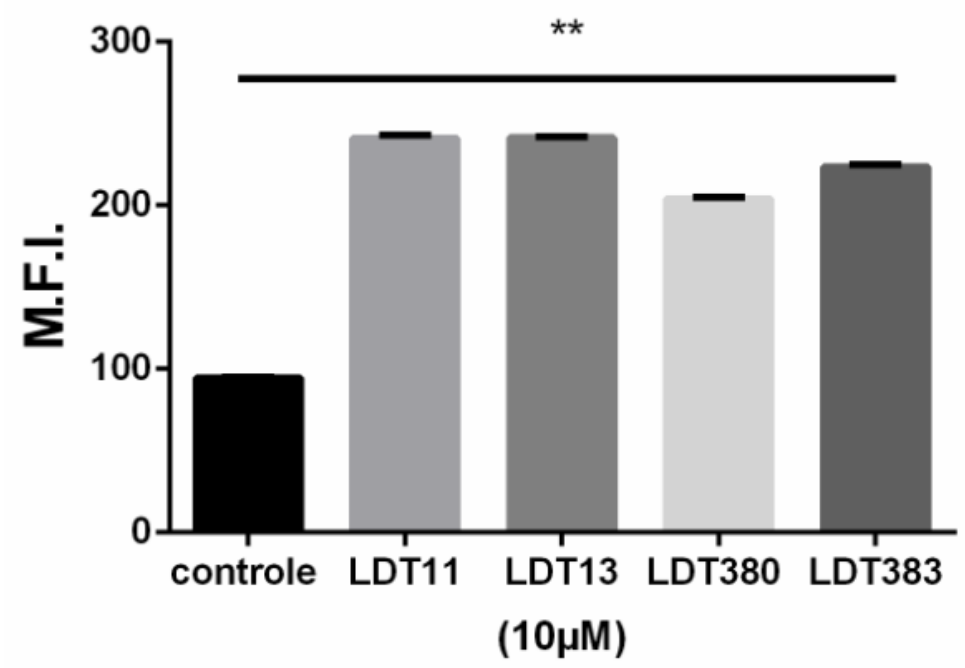

Figura 18 - Biogênese de corpúsculos lipídicos em células MDA-MB-231. (A) Tratamento com $10 \mu \mathrm{M}$ de LDT11, LDT13, LDT380 e LDT383 por 24h. Os histogramas mostram a curva do controle (células não estimuladas) em cinza e dos respectivos tratamentos. Cada imagem é representativa de três experimentos. (B) Quantificação da produção de corpúsculos lipídico sem células MDA-MB-231. O gráfico mostra a intensidade de fluorescência relativa de cada amostra. Cada coluna representa a média, com desvio padrão de três experimentos. $\mathrm{O}$ asterisco indica diferença significativa na produção de ROS entre as células tratadas com LDT13 e células não tratadas (controle) pelo teste one-way $\operatorname{ANOVA~}(* *) \mathrm{P}<0.01$. 


\subsubsection{LDT 13 promove o aumento da producão de Óxido Nítrico em MDA-MB-231}

Para avaliar se os compostos LDT11, LDT13, LDT380 e LDT383 afetariam a produção de NO em MDA-MB-231, as células foram estimuladas com $10 \mu \mathrm{M}$ de cada droga por $24 \mathrm{~h}$. Células não tratadas foram utilizadas como controle. Em seguida as amostras foram analisadas quanto à produção de nitrito pela reação de Griess, como uma medida da produção de NO. A leitura foi feita no SpectraMax.

O composto LDT13 induziu aumento significativo na produção de NO quando comparado com o controle, enquanto os demais compostos não induziram alterações significativas (figura 19).

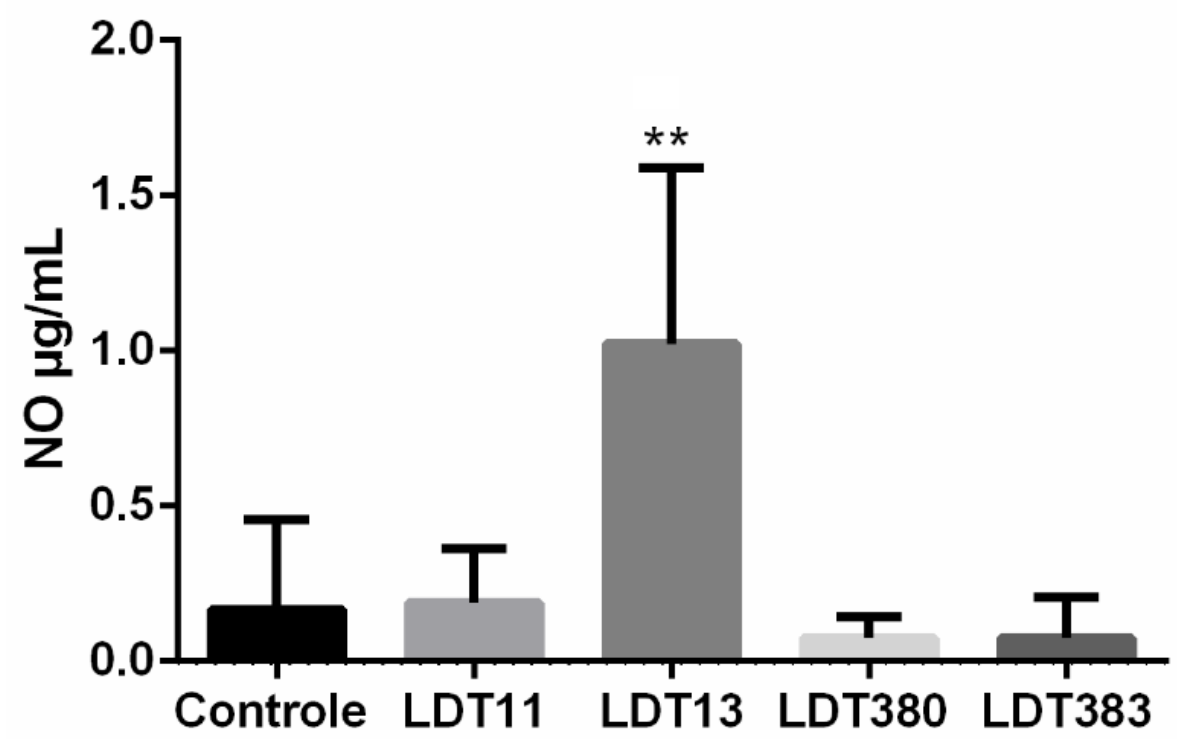

Figura 19 - Produção de Óxido Nítrico em células MDA-MB-231. (A) Tratamento com $10 \mu$ M de LDT11, LDT13, LDT380 e LDT383 por 24h. O gráfico de barras mostra a quantidade de NO em $\mu \mathrm{G} / \mathrm{mL}$ detectada em cada amostra. Cada coluna representa a média, com desvio padrão de três experimentos. $\mathrm{O}$ asterisco indica diferença significativa na produção de NO entre as células tratadas com LDT13 e células não tratadas (controle) pelo teste one-way ANOVA (**) $\mathrm{P}<0.01$. 


\subsubsection{LDT 13 e LDT383 induzem aumento na expressão do receptor nuclear PPAR}

Para saber se os compostos LDT11, LDT13, LDT380 e LDT383 afetariam a expressão de PPAR $\gamma$ em MDA-MB-231, as células foram estimuladas com $10 \mu \mathrm{M}$ de cada droga por 24h. Células não tratadas foram utilizadas como controle. Em seguida foi realizada extração de proteínas totais das amostras e posteriormente foi feita análise através de Western Blotting.

O resultado mostra um aumento acentuado da expressão de PPAR $\gamma$ após estímulo com LDT13 e seu isômero LDT383 (figura 20).

A.

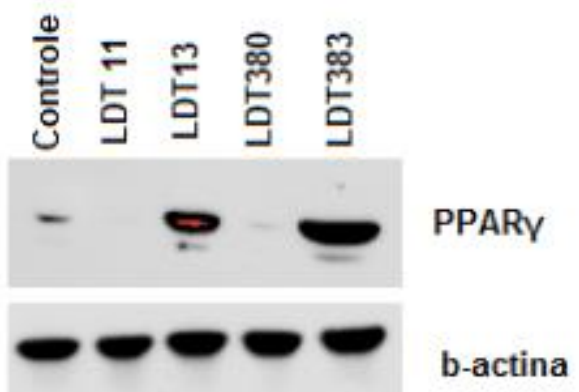

B.

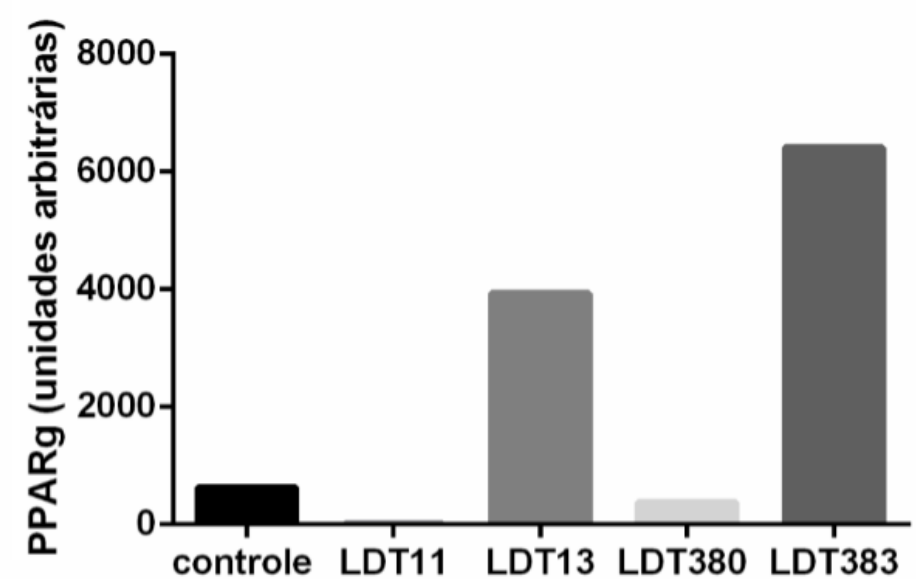

Figura 20 - Expressão de PPAR $\gamma$ em MDA-MB-231 após estímulo com LDT11, LDT13, LDT380 e LDT383. (A) Expressão de PPAR $\gamma(58 \mathrm{KDa})$ e b-actina (42 KDa). (B) Quantificação através da densitometria das bandas. 


\subsubsection{Efeitos dos compostos LDT11, LDT13, LDT380 e LDT383 na expressão de 5-LO}

Para saber se os compostos LDT11, LDT13, LDT380 e LDT383 afetariam a expressão de 5-LO em MDA-MB-231, as células foram estimuladas com $10 \mu \mathrm{M}$ de cada droga por 24h. Células não tratadas foram utilizadas como controle. Em seguida foi realizada marcação com anticorpo primário anti 5-LO e secundário Alexa-546. Para visualização dos núcleos das células foi feita marcação com DAPI.

Durante a visualização das lâminas no microscópio confocal, foi possível observar que os compostos LDT11, LDT380 e LDT383 aumentaram a expressão de 5-LO, enquanto as células estimuladas com LDT13 se apresentaram mais semelhantes ao controle (figura 21). 


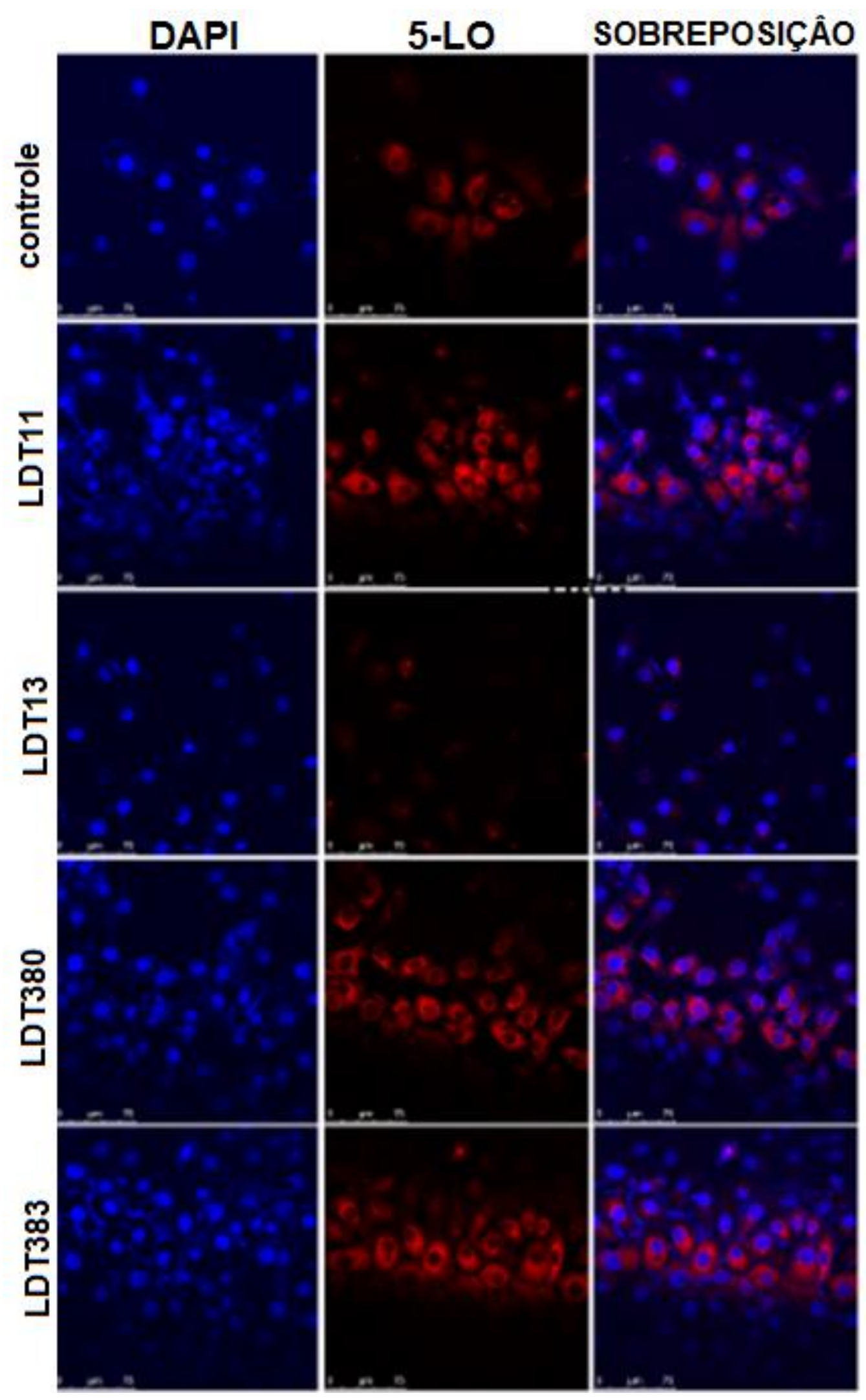

Figura 21 - Expressão de 5-LO em células MDA-MB-231 após estímulo com LDT11, LDT13, LDT380 e LDT383. As células foram tratadas com $10 \mu \mathrm{M}$ de LDT11, LDT13, LDT380 e LDT383 por 24h. Foi utilizada lente objetiva de $63 x$. 


\subsubsection{Efeitos dos compostos LDT11, LDT13, LDT380 e LDT383 na expressão de NFKB}

Para saber se os compostos LDT11, LDT13, LDT380 e LDT383 afetariam a expressão de NFкB em MDA-MB-231, as células foram estimuladas com $10 \mu \mathrm{M}$ de cada droga por cerca de 16h. Células não tratadas foram utilizadas como controle. Em seguida foi realizada marcação com anticorpo primário anti-NFkB e secundário Alexa-546. Para visualização dos núcleos das células foi feita marcação com DAPI.

Durante a visualização das lâminas no microscópio confocal, foi possível observar que o composto LDT13 promoveu translocação de NFkB para o núcleo. Essa translocação, no entanto, ocorreu apenas em parte das células. Os outros compostos não apresentaram translocação de NFкB para o núcleo, semelhante ao controle de células não tratadas (figura 22). 


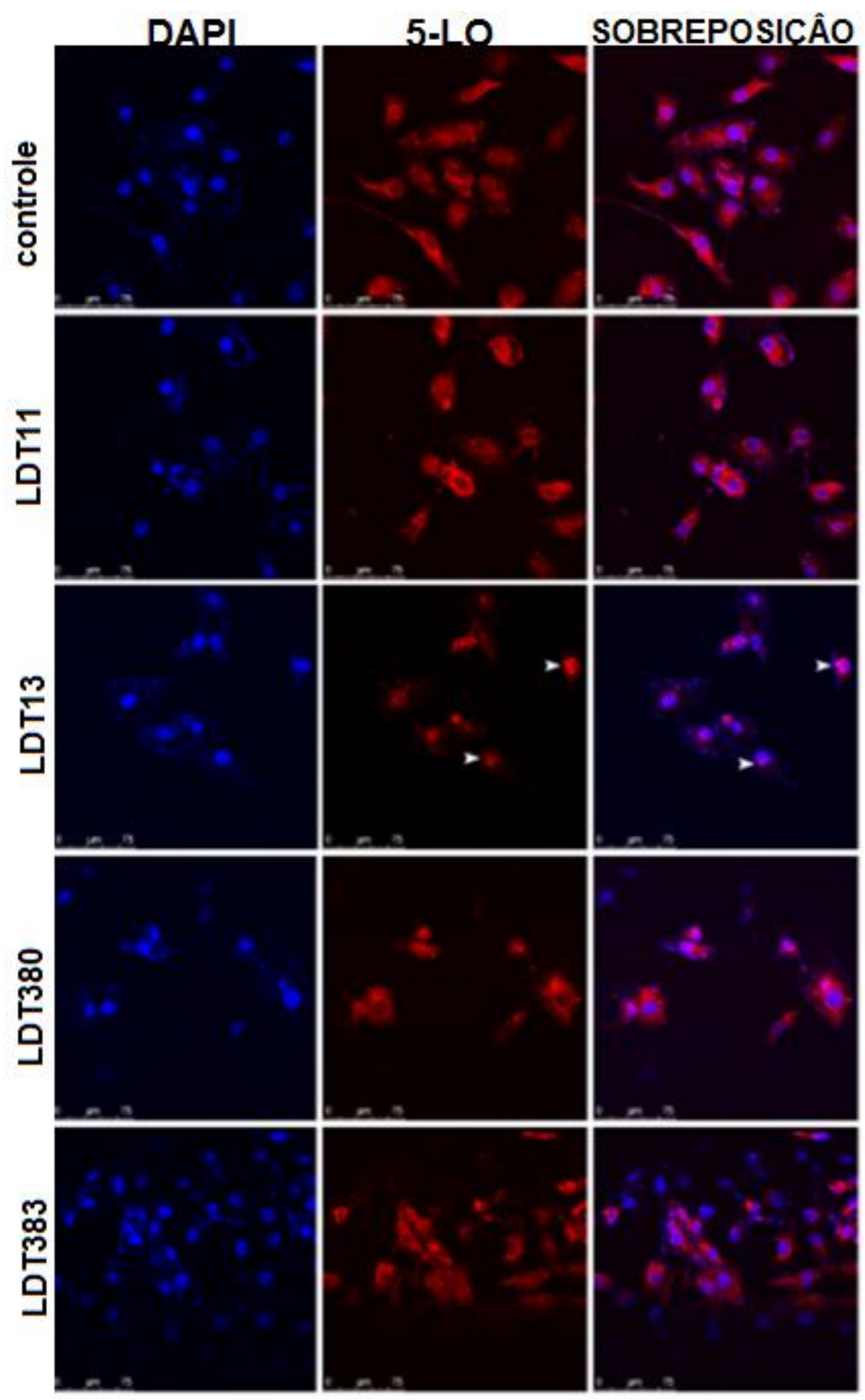

Figura 22 - Translocação de NFkB para o núcleo em células MDA-MB-231 tratadas com LDT13. As células foram tratadas com 10 $\mu \mathrm{M}$ de LDT11, LDT13, LDT380 e LDT383 por 16h. As setas indicas células onde ocorreu a translocação de NFkB para o núcleo. Foi utilizada lente objetiva de $63 x$. 


\subsubsection{Docking com os compostos LDT11, LDT13, LDT380 e LDT383}

\subsubsection{Docking com LDT11}

Na primeira análise de docking, onde não se colocou nenhuma molécula ocupando o ambiente do sítio ativo, o LDT11 não mostrou nenhum tipo de interação com os resíduos que caracterizam uma interação mais forte, realizando interação principalmente com a ARG288 (figura 23).

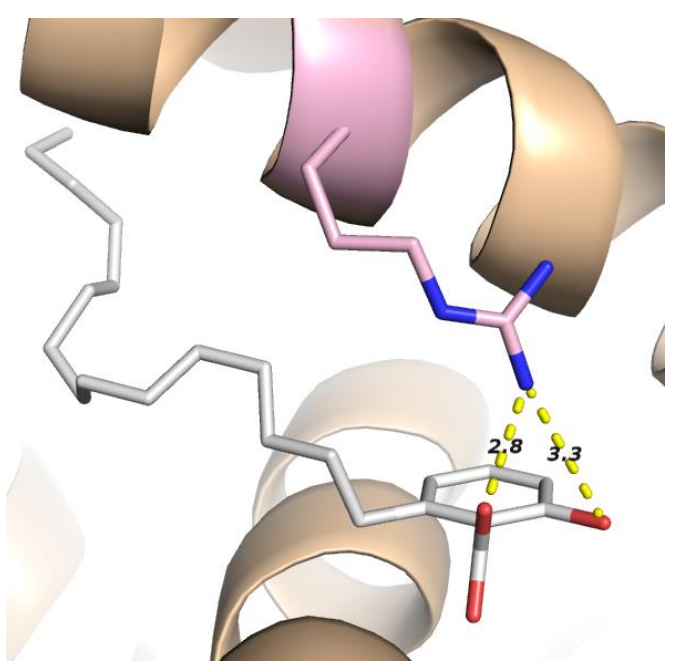

Figura 23 - Docking com LDT 11. Interações polares (pontilhado em amarelo e o distância em ångström, Å) entre o ligante LDT11 (branco) com os aminoácidos ARG288 (rosa) da proteína PPAR $\gamma$ (2VSR).

Quanto ao docking com a proteína rígida ocupando a fenda do sítio ativo do PPAR $\gamma$, primeiramente foi colocado o ligante 9-(S)-HODE (ITOH et al., 2008) na posição de interação com a ARG288. Pode-se observar na figura 24 que o LDT11 interage com os resíduos de aminoácido SER289, HIS323, TYR327 e TYR473.

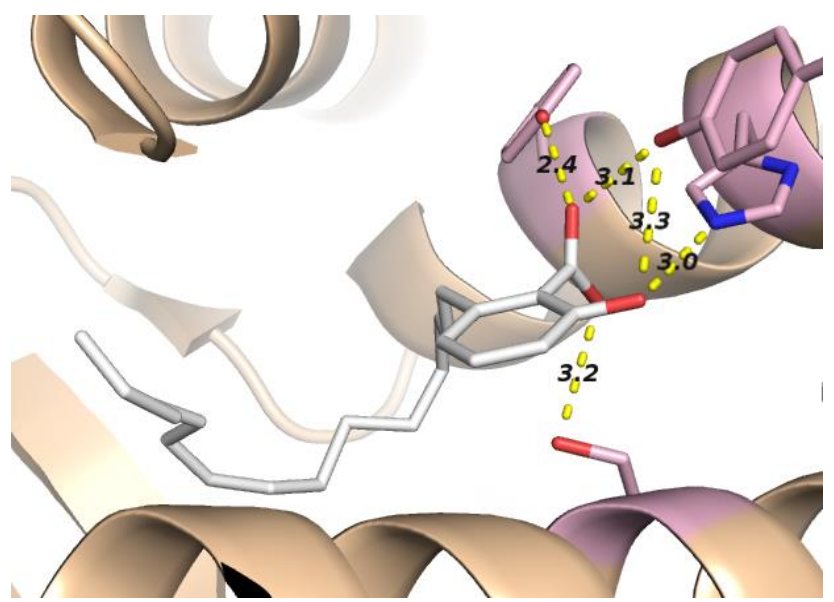

Figura 24- Docking com LDT11 e o ligante 9-(S)-HODE. Interações polares (pontilhado em amarelo e o distância em ångström, ̊̊) entre o ligante LDT11 (branco) com os aminoácidos HIS323, TYR327, TYR473 e SER (rosa) da proteína PPAR $\gamma$ (2VSR) ocupando o sítio de interação da ARG228 com o 9-(S)-HODE. 
Por sua vez, ao ocupar a posição de interação com a TYR473, o LDT11 volta a fazer interação com a ARG288 e com o grupamento amino da cadeia principal da LEU436.

\subsubsection{Docking com LDT13}

O LDT13, de modo bem semelhante ao LDT11, no docking sem nenhum ligante presente na fenda do sítio ativo da PPAR $\gamma$ apresentou interação com a ARG288, entretanto esta também mostrou interação com a SER289. Por sua vez, ao ocupar a região próxima a ARG288 com o ligante 9-(S)-HODE o ligante em questão passou a realizar interação com os aminoácidos SER289, HIS323, HIS449 e TYR473 (Figura 25). Entretanto, ao ocupar o sítio próximo a TYR473 com o ligante original da PPAR $\gamma$ (2VSR) o LDT13 interagiu com a ARG280.

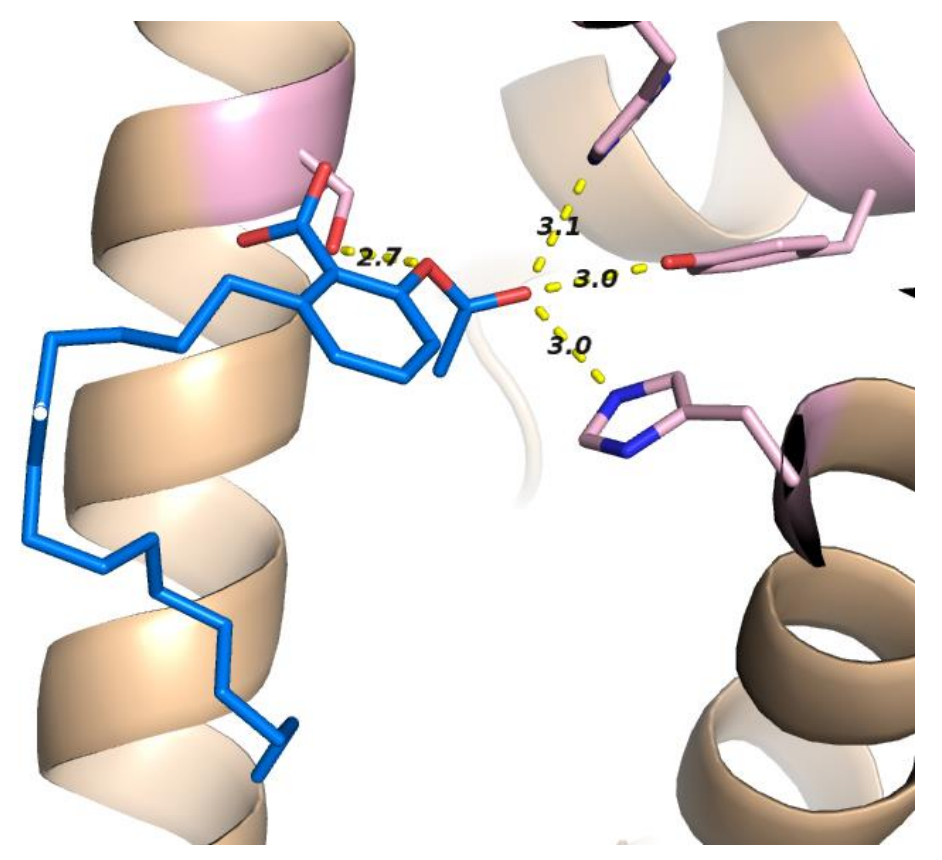

Figura 25 - Docking com LDT13. Interações polares (pontilhado em amarelo e o distância em ångström, Å) entre o ligante LDT13 (azul) com os resíduos de aminoáciodo SER289, HIS323, HIS449 e TYR473 (rosa) da proteína PPAR $\gamma$ (2VSR) ao ocupar o sítio de interação da ARG288 com o 9-(S)-HODE 


\subsubsection{Docking com LDT380}

Em se tratando do LDT380, no docking com a fenda do sítio ativo vazio, este ligante apresentou interações com a ARG288. Quando ocupou o sítio de interação da TYR473 com o ligante 9-(S)-HODE, o LDT380 apresentou interação com a ARG280. Por último, foi ocupado o sítio de interação com a ARG288 e o ligante em questão se apresentou interação com os resíduos TYR327 e LYS367 (figura 27), apesar da proximidade com a TYR473 não apresentou interação polar com esta.

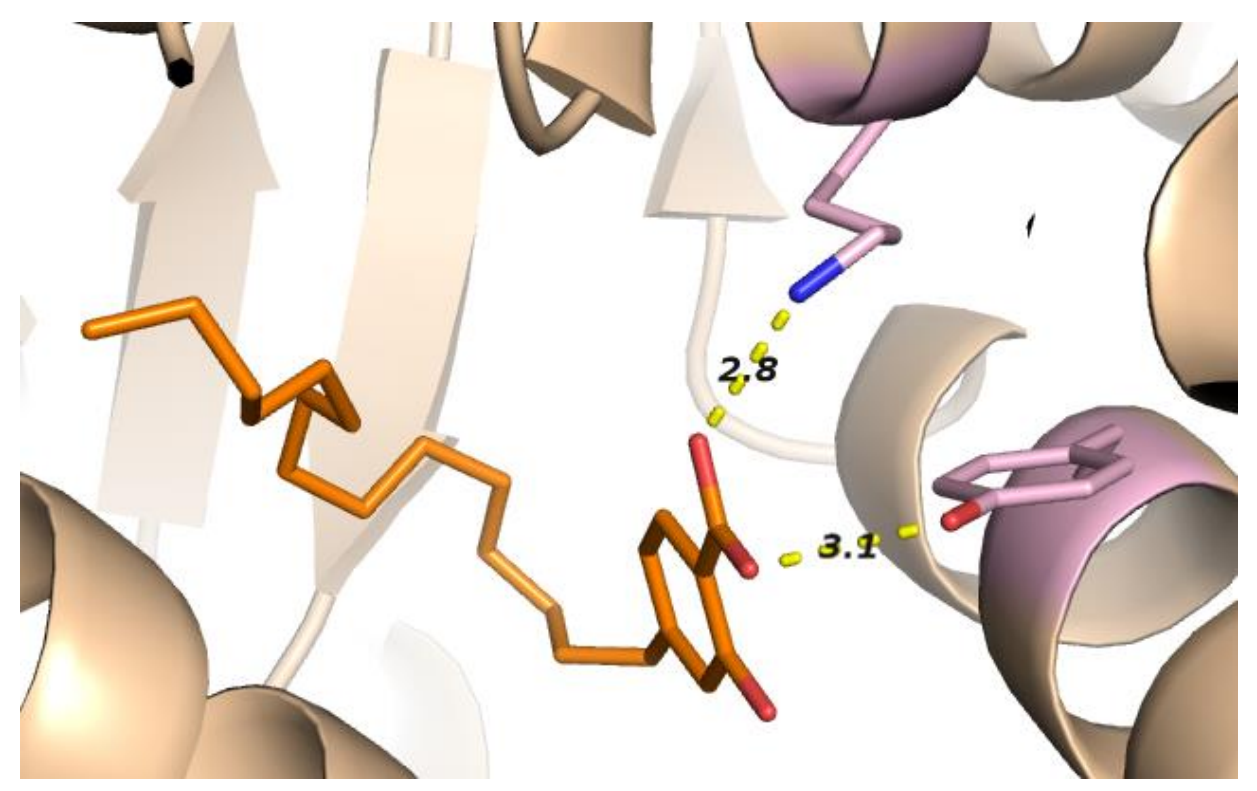

Figura 26- Docking com LDT380. Interações polares (pontilhado em amarelo e o distância em ångström, Å) entre o ligante LDT380 (laranja) com os resíduos de aminoácidos TYR327 e LYS367 (rosa) da proteína PPAR $\gamma$ (2VSR) ocupando o sítio de interação da ARG288 com o 9-(S)-HODE.

\subsubsection{Docking com LDT383}

Quanto ao ligante LDT383 foi observado no experimento de docking sem ligantes na fenda do sítio ativo da proteína PPAR $\gamma$ a interação deste com o resíduo ARG288, como quase todos os ligantes aqui estudados. No experimento de docking onde o sítio da TYR473 foi ocupado com o 9-(S)-HODE o LDT383, por sua vez, mudou a sua interação para a ARG280. 
Quanto ao docking ocupando o sítio de interação com a ARG288, o LDT383 apresentou interações com os resíduos HIS323, TYR327, LYS367, HIS449 e TYR473 (figura 27).

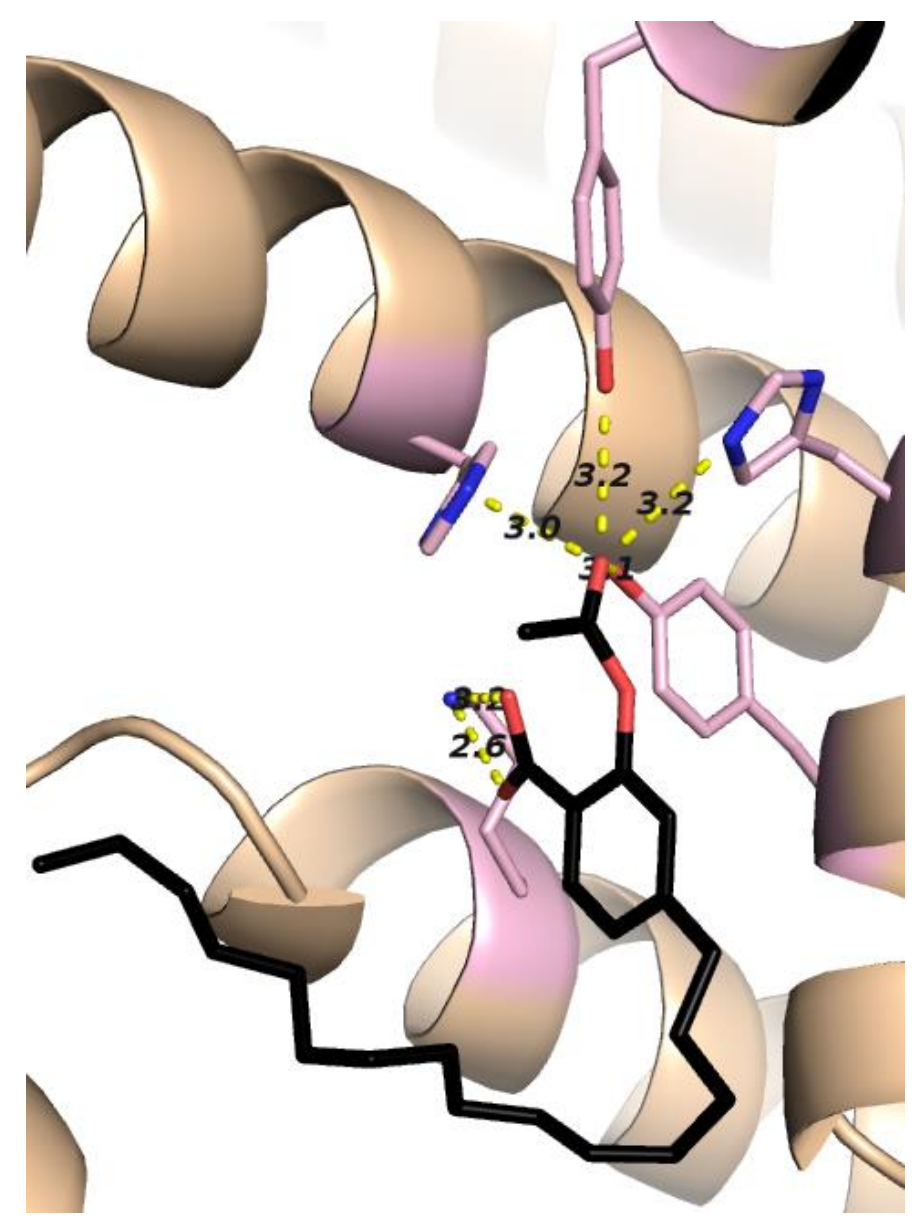

Figura 27- Docking com LDT383. Interações polares (pontilhado em amarelo e o distância em ångström, ̊̊) entre o ligante LDT383 (preto) com os resíduos de aminoácidos HIS323, TYR327, LYS367, HIS449 e TYR473. 


\subsubsection{Compilação dos resultados}

Os resultados se encontram compilados na tabela 2 para melhor visualização.

\begin{tabular}{|c|c|c|c|c|}
\hline \multirow{2}{*}{ Análise } & \multicolumn{4}{|c|}{ Estímulos } \\
\cline { 2 - 5 } & LDT11 & LDT13 & LDT380 & LDT383 \\
\hline Viabilidade & $\downarrow \downarrow$ & $\downarrow \downarrow \downarrow$ & $\downarrow$ & $\downarrow$ \\
\hline Proliferação & $\downarrow \downarrow$ & $\downarrow \downarrow \downarrow$ & $\downarrow$ & $\downarrow$ \\
\hline Apoptose & $\uparrow$ & $\uparrow$ & $\uparrow \uparrow$ & $\uparrow \uparrow$ \\
\hline Fragmentação nuclear & $\uparrow$ & $\uparrow$ & $\uparrow$ & $\uparrow \uparrow$ \\
\hline Migração & $\downarrow \downarrow$ & $\downarrow \downarrow$ & $\downarrow$ & $\downarrow$ \\
\hline Corpúsculo lipídico & $\uparrow$ & $\uparrow$ & $\uparrow$ & $\uparrow$ \\
\hline ROS & - & + & - & - \\
\hline NO & - & + & - & - \\
\hline 5-LO & $\uparrow$ & $\downarrow$ & $\uparrow$ & $\uparrow$ \\
\hline Translocação de NFkB & - & + & - & - \\
\hline PPAR & - & $\uparrow$ & - & $\uparrow$ \\
\hline
\end{tabular}

Tabela 2. Compilação dos resultados. Efeitos de cada tratamento sobre cada parâmetro analisado. 


\section{Discussão}

O Câncer de mama é um dos tipos de câncer com maior incidência no mundo (WHO, 2014). A principal terapia endócrina efetiva para o tratamento desta patologia são os antiestrógenos, mas as alternativas terapêuticas são limitadas para tumores triplo negativos, que são frequentemente agressivos. O desenvolvimento de células tumorais resistentes aos agentes quimioterápicos é um dos maiores obstáculos para o sucesso do tratamento do câncer de mama, e isso se torna um forte estímulo para explorar novas abordagens terapêuticas in vitro. O uso de ligantes de receptores nucleares para inibir o crescimento e progressão tumoral é uma das novas promissoras estratégias para o tratamento de câncer.

Os ligantes de PPAR $\gamma$ vêm sendo estudados recentemente, porém ainda não há um consenso entre os pesquisadores em relação aos seus efeitos no câncer mamário. Alguns estudos indicam que antagonistas do PPAR $\gamma$ inibem o crescimento e promovem apoptose em células de tumor de mama (SAEZ et al., 2004; ZAYTSEVA et al., 2008; ZAYTSEVA et al., 2011). Já outros pesquisadores atribuem estes mesmos efeitos de inibição de crescimento e estímulo da apoptose à agonistas de PPAR $\gamma$ (YU et al, 2008; SHASHNI et al., 2013).

Apesar de existirem estudos com resultados divergentes em relação à expressão de PPAR $\gamma$ e desenvolvimento tumoral, a maioria das pesquisas mostra uma correlação das vias ativadas por PPAR $\gamma$ à sobrevivência e outros aspectos tumorigênicos do câncer de mama. Como reguladores importantes do metabolismo, estas vias parecem exercer um papel central na progressão e desenvolvimento do carcinoma de mama, e os detalhes de sua modulação poderiam ser úteis no desenvolvimento de novas terapias em oncologia. Considerando essa possibilidade, fomos investigar o efeito de derivados do ácido anacárdico com perfil agonista parcial de PPAR $\gamma$ em linhagens celulares de adenocarcinoma de mama, verificando se a modulação deste receptor nuclear alteraria as propriedades do modelo in vitro de câncer mamário.

A etapa inicial deste trabalho se ateve à realização de uma triagem de compostos sintetizados no Laboratório de Desenvolvimento de Estratégias Terapêuticas da UnB (LADETER), para verificação da existência de alterações na viabilidade e proliferação de células de adenocarcinoma de mama.

Dentre os compostos testados inicialmente, o composto LDT13 foi o que apresentou os melhores resultados de redução de viabilidade e proliferação de células tumorais. Estes resultados são condizentes com o estudo de ancoragem molecular (molecular docking) 
realizado por nossos colaboradores, no qual o LDT13 apresentou uma afinidade maior pelo sítio ativo do receptor PPAR $\gamma$ do que os compostos LDT15 e LDT29.

Em virtude de tais resultados, decidimos excluir os compostos LDT15 e LDT29 e prosseguir as análises com LDT13. Os compostos LDT11, LDT380 e LDT383 foram incluídos na segunda etapa do estudo por causa de sua semelhança com o LDT13.

A segunda parte do trabalho se ateve a investigar se o estímulo com as drogas LDT11, LDT13, LDT380 e LDT383 afetaria a viabilidade, proliferação e ciclo celular em células de tumor de mama. Além disso, também investigamos o efeito dos compostos na expressão de NFkB e do mediador inflamatório 5-LO, na formação de corpúsculos lipídicos e na produção de ROS e NO.

Nossos dados mostram que o tratamento com os compostos LDT11, LDT13, LDT380 e LDT383 promovem uma redução na viabilidade celular e um aumento na apoptose de células de adenocarcinoma de mama (figuras 10 e 13). O ensaio de MTT mostra uma maior redução de viabilidade após os tratamentos com LDT11 e LDT13, já a marcação com Anexina-V/ PI mostra um maior percentual de apoptose depois do tratamento com LDT380 e LDT383. Uma possível explicação para esta discrepância pode ser o fato de que o ensaio de MTT mostra o percentual de viabilidade celular em função da funcionalidade mitocondrial, enquanto o ensaio com Anexina-V mostra o percentual de morte por apoptose baseado na exposição de fosfatidilserina no lado externo da membrana plasmática. O composto LDT13 gera um aumento na produção de ROS e de NO, e talvez isso cause danos oxidativos na mitocôndria, prejudicando seu funcionamento e reduzindo a viabilidade celular de forma mais intensa do que os outros compostos no ensaio de MTT. Além disso, o tempo de estímulo para os dois ensaios foi diferente, no ensaio de MTT as células foram tratadas por 48h, enquanto na marcação com Anexina-V/ PI o estímulo foi de $24 \mathrm{~h}$.

O resultado da marcação com PI para avaliar ciclo celular e fragmentação nuclear (figuras 15 e 16) estão condizentes com o resultado do ensaio para avaliar apoptose. O maior percentual de fragmentação nuclear ocorreu nas células tratadas com o composto LDT383, mesmo composto que promoveu o percentual mais alto de apoptose. Em relação à análise do ciclo celular, foi possível observar alterações significativas promovidas pelos compostos LDT11 e LDT383. Este resultado foi semelhante aos resultados obtidos por Yu e colaboradores que avaliou o efeito do agonista de PPAR $\gamma$ Troglitazona em células MDA-MB231, no qual ocorreu parada do ciclo celular na fase G1 (YU et al, 2008). No tratamento com 
LDT13, não houve alteração significativa do ciclo celular, porém houve uma tendência de redução na fase G2/M.

Neste trabalho, além de observar redução de viabilidade e aumento de apoptose, vimos também uma diminuição na proliferação das células tumorais tratadas com os compostos LDT11, LDT13, LDT380 e LDT383 (figura 11). Trabalhos anteriores que testaram outros agonistas parciais de PPAR $\gamma$ nas linhagens celulares MDA-MB-231 e MCF-7 tiveram resultados parecidos com os que obtivemos (SHASHNI et al., 2013; PAL et al, 2014). Assim como ocorreu no ensaio de MTT, no ensaio clonogênico a redução na proliferação foi mais acentuada nas células tratadas com LDT13. O segundo composto mais eficiente no ensaio de MTT foi o LDT11, e o mesmo ocorreu no ensaio clonogênico. O tempo de estímulo com os compostos LDT11, LDT13, LDT380 e LDT383 foi o mesmo nos dois ensaios.

A metástase é a principal causa de morte em pacientes com câncer. Seu início se dá a partir do momento em que células tumorais se desprendem do tumor primário e migram em direção ao seu sítio metastático (YILMAZ e CHRISTOFORI, 2010). Para avaliar o efeito dos compostos LDT11, LDT13, LDT380 e LDT383 na migração de células de adenocarcinoma de mama invasivo, realizamos o ensaio de wound healing na linhagem MDA-MB-231. Em concordância com os resultados dos ensaios de MTT e ensaio clonogênico, o composto LDT13 foi o que reduziu de forma mais intensa a migração das células. O composto LDT11 foi o segundo mais eficiente na redução da migração celular. Os isômeros não inibiram a migração de forma tão acentuada, mas ainda assim promoveram uma redução significativa no fechamento da "ferida" quando comparados com o controle não tratado (figura 14).

Quanto à biogênese de corpúsculos lipídicos, os resultados obtidos são semelhantes aos já encontrados na literatura, com ligantes de $\operatorname{PPAR} \gamma$ promovendo o aumento da quantidade de corpúsculos (BURGUERMEISTER et al, 2003; ACCIOLY et al, 2008). Os compostos LDT13 e LDT11 foram os compostos que promoveram uma elevação mais intensa na biogênese de corpúsculos lipídicos, enquanto seus ligantes geraram um aumento um pouco menor porém significativo (figura 18). Este aumento significativo no número de corpúsculos lipídicos sugere ativação de PPAR $\gamma$, pois a regulação das vias de captação de ácidos graxos e de armazenamento lipídico depende da translocação de PPAR $\gamma$ para dentro do núcleo (BOZZA e VIOLA, 2010).

A produção de ROS em células tratadas sofreu elevação significativa somente após estímulo com o composto LDT 13. O estímulo com o isômero do LDT 13 apresentou uma 
tendência de aumento da produção de ROS, porém este resultado não foi significativo. Já os compostos LDT11 e LDT380 não promoveram alterações na produção de ROS.

$\mathrm{O} N F \kappa B$ é um importante fator de transcrição que está associado a processos inflamatórios, e que pode regular a expressão de diversos genes que estão envolvidos no crescimento celular, diferenciação e apoptose (MORGAN e LIU, 2011). ROS interagem com $\mathrm{NF \kappa B}$ de diversas maneiras. Já foi proposto que ROS podem tanto ativar quanto inativar o complexo IKK, levando a efeitos nos alvos a jusante da via. Tem sido mostrado com

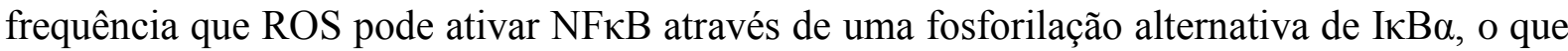

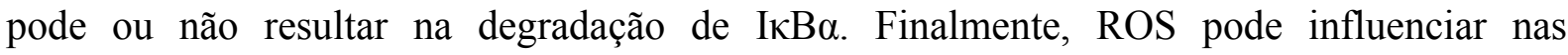
propriedades de ligação das proteínas NFkB ao DNA. A oxidação de p50 no seu domínio de ligação ao DNA previne sua ligação ao DNA, e deve ser revertida no núcleo por um processo dependente de Trx1 envolvendo Ref-1. Por outro lado a fosforilação de Rel-A, que é influenciada por processos dependentes de ROS, leva a uma maior ativação de NFkB (MORGAN e LIU, 2011).

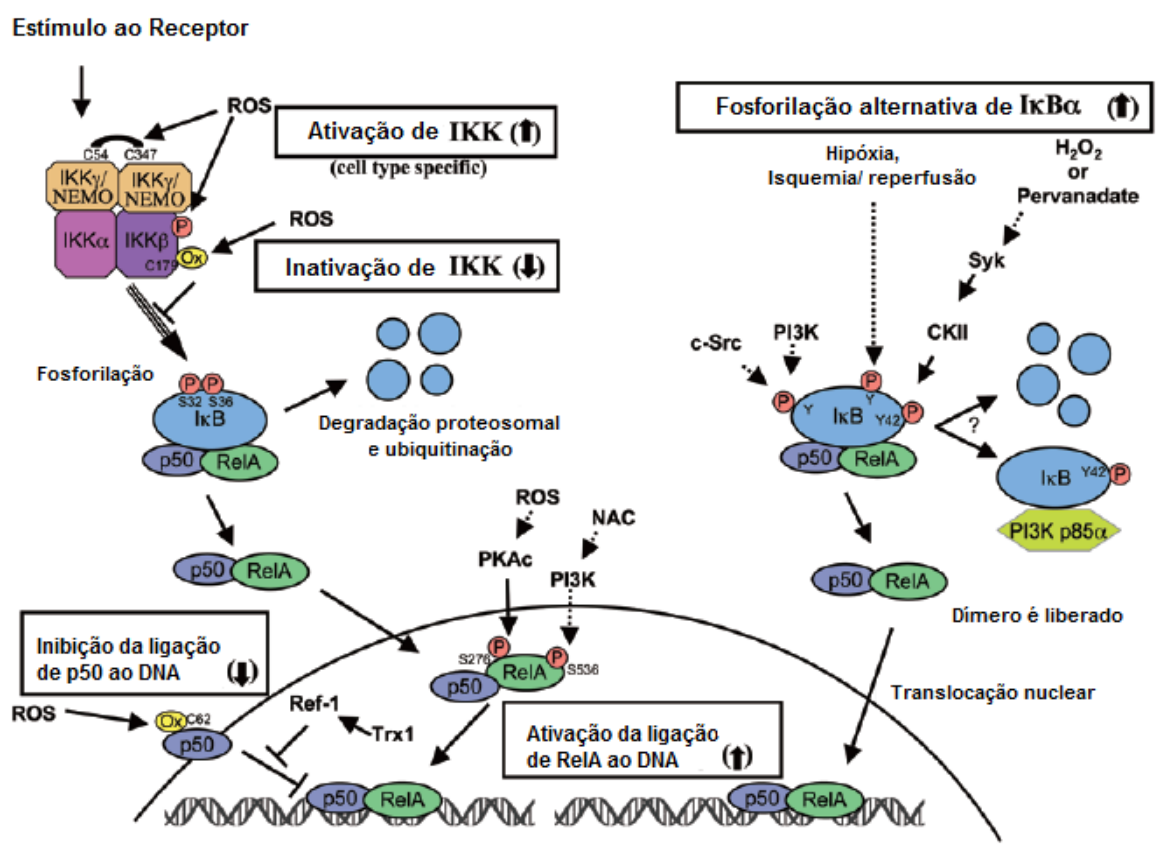

Figura 28 - Interferência de ROS nas vias de sinalização de NFкB. Adaptado de MORGAN e LIU, 2011.

Nossos resultados mostram que ocorreu translocação de NFאB para o núcleo apenas em algumas células na amostra tratada com LDT13 (figura 22). Este composto também foi o único que aumentou a produção de ROS de forma significativa. Talvez este aumento tenha interferido nas vias de sinalização de $\mathrm{NF \kappa B}$, induzindo sua translocação para o núcleo. $\mathrm{Na}$ 
maioria dos casos, a expressão dos genes alvo de NFkB promove a sobrevivência das células, porém em alguns casos sua expressão pode contribuir para morte celular (PERKINS e GILMORE, 2006).

A Óxido nítrico sintase induzível (iNOS) é regulada positivamente pelo NFкB (MORGAN e LIU, 2011). iNOS produz espécies reativas de nitrogênio, como o NO, que é frequentemente produzido onde pode reagir com superóxido levando à formação de peroxinitrito altamente reativo. O peroxinitrito pode causar diversos tipos de dano celular, como dano ao DNA, e ativar vias de morte celular (MORGAN e LIU, 2011). Neste trabalho dosamos a produção de NO após estímulo com os compostos LDT13, LDT11, LDT380 e LDT383. Somente o estímulo com LDT13 produziu uma elevação significativa na produção de NO quando comparado com o controle (figura 19). Este resultado é compatível com os resultados dos ensaios de MTT e ensaio clonogênico, que mostram o composto LDT13 reduzindo a viabilidade e a proliferação de forma mais intensa do que os demais compostos testados.

Avis e colaboradores sugeriram que enzimas que metabolizam AA exercem um papel significante na carcinogênese mamária através de processos oxidativos (AVIS et al, 2001). No presente trabalho a expressão de 5-LO também foi investigada. As células tratadas com o composto LDT13 foram as que apresentaram a expressão mais baixa de 5-LO. Este resultado é condizente com estudos que relacionam uma redução na expressão de 5-LO com redução na proliferação e aumento de morte celular em linhagens de adenocarcinoma de mama (AVIS et al, 2001). Os compostos LDT11, LDT380 e LDT383 aparentemente não promoveram redução na expressão de 5-LO (figura 21).

$\mathrm{Na}$ literatura vemos que a interação entre algumas moléculas e o PPAR $\gamma$ pode ocorrer de formas diversas. Um dos modos de interação é o modo agonista pleno, onde o agonista interage com a TYR473, localizada na hélice 12, e com outros resíduos próximos como a HIS323 e HIS449. Outro modo de interação, o agonista parcial, é representado por interação com a hélice 3 e com a região de folhas- $\beta$, principalmente com os resíduos ARG288, GLU291 e GLU343 (NETTLES, 2008).

A interação entre PPAR $\gamma$ e ácidos graxos ocorre de forma um pouco diferente pois essa pode ocorrer concomitantemente entre a proteína e dois ligantes (LI et al., 2008), e com até três ligantes dentro da região do sítio ativo da proteína (LIBERATO et al., 2012). Sendo assim, a interação com ácidos graxos se mostram como um conjunto de ligações de baixa afinidade (NETTLES, 2008), onde ocorre interação em ambos os sítios anteriormente citados. 
No presente trabalho observou-se que os ligantes LDT11, LDT13, LDT380 e LDT383 apresentaram capacidade de interagir tanto com a região da ARG288 quanto com a da TYR473. Isso pode indicar que estes ligantes apresentam interações mais fortes, pelo fato de conseguirem interagir com ambos os sítios do PPAR $\gamma$. Já outros compostos, como o LDT 29, apesar de interagirem com a região da ARG288 não apresentaram interação com a da TYR473, realizando uma interação mais fraca.

A análise da expressão de PPAR $\gamma$ por Western Blot revelou um resultado esperado para o composto LDT13 e seu isômero LDT383, que promoveram um aumento expressivo nos níveis de PPAR $\gamma$. Entretanto, no docking o LDT380 não apresentou interações diretas com o resíduo TYR473, mas com os resíduos TYR327 e LYS367. Este fato pode indicar uma menor atividade da proteína (LI et al., 2008), e está de acordo com o resultado que observamos no Western Blot. Na análise da expressão de PPAR $\gamma$ por Western Blot vemos que não ocorre um aumento expressivo nos níveis de PPAR $\gamma$ após estímulo com LDT380.

Assim como seu isômero, o LDT11 também não aumenta a expressão de PPAR $\gamma$. Este resultado foi diferente do que esperávamos que acontecesse. Isso pode ser um indicativo de que LDT11 e LDT380 exercem efeitos independentes de PPAR $\gamma$.

\section{Conclusões}

O conjunto de dados obtidos em nosso trabalho mostra pela primeira vez que os compostos LDT11, LDT13, LDT380 e LDT383 são capazes de promover redução na viabilidade, proliferação e migração de células de adenocarcinoma de mama, sem diminuir a viabilidade de células não tumorais (PBMCs). Também mostramos que estes compostos levam a um aumento de fragmentação nuclear e apoptose, e que o LDT 11 e LDT 383 promovem modificações significativas no ciclo celular. Com base nesses resultados, sugerimos que os compostos LDT11, LDT13, LDT380 e LDT383 podem servir como potenciais agentes terapêuticos contra o câncer de mama no futuro.

Nossos resultados mostram uma relação entre LDT13, PPAR $\gamma$, ROS e NO que não havia sido reportada anteriormente na literatura. Os efeitos de redução na viabilidade e proliferação promovidos pelo LDT13 podem ser justificados pelo aumento na produção de ROS e NO, e pela ativação do PPAR $\gamma$ que costuma exercer propriedades antitumorais. Esses dados acrescentam assim uma nova dimensão ao potencial terapêutico de ligantes de PPAR $\gamma$. Embora o mecanismo exato ainda não esteja claro e mais estudos ainda sejam necessários para esclarecer o mecanismo de ação molecular do PPAR $\gamma$ na carcinogênese mamária, nossa 
investigação abriu uma nova direção para o desenvolvimento de potenciais drogas para o tratamento do câncer de mama.

Dessa forma, mais estudos são imprescindíveis para um entendimento mais profundo do mecanismo de ação antitumoral dos compostos LDT11, LDT13, LDT380 e LDT383. Novas investigações sobre estes compostos poderão eventualmente ajudar-nos na compreensão dos mecanismos moleculares pelos quais PPAR $\gamma$ regula alvos que influenciam especificamente o câncer de mama. Apesar de vários avanços terem sido feitos no assunto, ainda há muito a ser esclarecido sobre a sinalização de PPAR $\gamma$ no câncer de mama e várias questões importantes permanecem sem resposta. Muitos caminhos intrigantes da pesquisa derivados do ácido anacárdico foram abertos e têm o potencial de, em última instância conduzir ao desenvolvimento novas classes de fármacos mais seletivos e com menos efeitos adversos.

\section{Perspectivas}

Diante da necessidade de mais estudos envolvendo os efeitos dos compostos LDT11, LDT13, LDT380 e LDT383 no câncer de mama, temos como perspectivas:

- Identificar os mecanismos de ação dos compostos dependentes e independentes de PPAR $\gamma$.

- Realizar testes em camundongos para avaliar o efeito dos compostos in vivo. 


\section{$\underline{\text { Referências }}$}

ACCIOLY et al. Lipid Bodies Are Reservoirs of Cyclooxygenase-2 and Sites of Prostaglandin-E2 Synthesis in Colon Cancer Cells. Cancer Res, v.68, n.6, p. 17321740, 2008.

AKBIYIK, F. et al. Human bone marrow megakaryocytes and platelets express PPAR $\gamma$, and PPAR $\gamma$ agonists blunt platelet release of CD40 ligand and thromboxanes. Blood, v.104, p. 1361-1368, 2004.

ALVES, P. S. Síntese e avaliação biológica de novos agentes anti-inflamatórios planejados a partir do ácido anacárdico [ Dissertação]. Brasília: Universidade de Brasília, Faculdade de Saúde, Ciências Farmacêuticas; 2015.

AVIS, I. et al. Five-lipoxygenase inhibitors can mediate apoptosis in human breast cancer cell lines through complex eicosanoid interactions, FASEB J. v.15, p.306-377, 2001.

BALKWILL, F; MANTOVANI,A. Inflammation and câncer: back to Virchow? The Lancet, v.357, n.9255, p.539-545, 2001.

BANDEIRA-MELO, C; WELLER, F. P. Mechanisms of eosinophil cytokine release. Mem Inst Oswaldo Cruz 100 Suppl 1: 73-81, 2005.

BARONZIO, G.; FIORENTINI, G.; COGLE, C.R. Cancer Microenvironment and Therapeutic Implications: Tumor Pathophysiology Mechanisms and Therapeutic Strategies. In: BARONZIO, G.; FREITAS, I.; FIORENTINI, G.; CRUGNOLA, A.R.; HAGER, D., CEPPODOMO, D.; KISELEVSKY, M.V. 1a. Ed. Springer, 2009. c. 9 , p. 157.

BEATSON, G.T. On the treatment of inoperable cases of carcinoma of the mamma: suggestions for a new method of treatment with illustrative cases. Lancet, v.148, p.104-107, 1896.

BOOKOUT, A.L et al. Anatomical profiling of nuclear receptor expression reveals a hierarchical transcriptional network. Cell, v.126, n.4, p.789-99, Aug 252006.

BOZZA, P.T.; MAGALHÃES, K. G.; WELLER P. Leukocyte lipid bodies-biogenesis and functions in inflammation. Biochim. Biophys. Acta. v.1791, p.540-551, 2009.

BOZZA, P.T.; VIOLA, P. Lipid droplets in inflammation and cancer. Prostaglandins, Leukotrienes and Essential Fatty Acids, v. 82, p. 243-250, 2010. 
BOZZA, P. T et al. Eosinophil lipid bodies: specific, inducible intracellular sites for enhanced eicosanoid formation. J Exp Med, v.186, n. 6, p.909-20, 1997.

BURGUERMEISTER, E.; TENCER, L.; LISCOVITCH, M. Peroxisome proliferatoractivated receptor- $\boldsymbol{\gamma}$ upregulates caveolin-1 and caveolin-2 expression in human carcinoma cells. Oncogene, v.22, p. 388-3900, 2003.

BURNET, M. Cancer: a biological approach. I. The processes of control. British Medical Journal. v. 1, n. 5022, p. 779-786, 1957.

BURnet, M. The concept of immunological surveillance. Prog. Exp. Tumor. Res., v.13, p. $1-27,1970$.

CONNOLLY, J.M.; ROSE, D. P. Enhanced angiogenesis and growth of 12-lipoxygenase gene-transfected MCF-7 human breast cancer cells in athymic nude mice. Cancer Lett. v. 132, p. 107-12, 1998.

CROSARA, M.; BRAGHIROLI, M.I.; SABBAGA, J.; HOFF, P.M. Primary prevention of colorectal cancer: Myth or reality?. World Journal of Gastroenterology, v.20, n.41, p.15060-15069, 2014.

DAMTEW, B.; SPAGNUOLO, P.J. Tumor cell-endothelial cell interactions: evidence for roles for lipoxygenase products of arachidonic acid in metastasis. Prostag. Leuktr Ess Fatty Acid, v.56, p. 295-300, 1997.

DESVERGNE, B.; WAHLI, W. Peroxisome proliferator-activated receptor: nuclear control of metabolism. Endrocr Rev, v.20, n.5, p.649-88, Oct 1999.

DOUGAN, M.; DRANOFF, G. Immune therapy for cancer. Annual Review of Immunology. v. 27, p. 83-117, 2009.

EASTON DF, BISHOP, D.T.; FORD, D.; CROCKFORD, G.P. Genetic Linkage Analysis in Familial Breast and Ovarian Cancer: Results from 214 Families. Am J Hum Genet. v.52, p.678-701, 1993.

FACCIABENE, A. et al. Tumour hypoxia promotes tolerance and angiogenesis via CCL28 and T(reg) cells. Nature, v.13, p.226-230, 2011.

FERLA, R. et al. Founder mutations in BRCA1 and BRCA2 genes. Annals of Oncology, v.18, n.6, p.93-98, 2007.

FROÉS, P.I.R. Análise de Micronúcleos em Células da Mucosa Bucal Após Exposição Crônica e Abusiva ao Álcool. Monografia apresentada ao UniCeub. Brasília, julho de 2009.

GRONEMEYER, H. et al. Principles for modulation of the nuclear receptor superfamily. Nat Rev Drug Discov, v.3, n.11, p950-64, 2004. 
HEMSHEKHAR, M. et al. Emerging Roles of Anacardic Acid and Its Derivatives: A Pharmacological Overview. Basic \& Clinical Pharmacology \& Toxicology, v.110, p. 122-132, 2011.

HONN, K.V. Lipoxygenase metabolite, 12-(s)-HETE, stimulates protein-kinase cmediated release of cathepsin-b from malignantcells. Exp. Cell Res, v. 214, p.120 130, 1994.

HOWE, L.R. Transcriptional activation of cyclooxygenase-2 in Wnt-1-transformed mouse mammary epithelial cells. Cancer Res, v.59, p.1572-1577, 1999.

HOWE, L. R. et al. Celecyclooxygenaseib, a selective cyclooxygenase 2 inhibitor, protects against human epidermal growth factor receptor 2 (HER-2)/neu-induced breast cancer. Cancer Res, v.62, p. 5405-5407, 2002.

HUANG, J.T. Interleukin4 dependent production of PPAR gamma ligands in macrophages by 12/15 lipoxygenase. Nature, v. 400, n. 6742, p.378-82, 1999.

INCA. Estimativa 2014: Incidência de cancer no Brasil. Rio de Janeiro, 2014. p.35.

ISHIGAMI, S.; NATSUGOE, S.; TOKUDA, K. Clinical impact of intratumoral natural killer cell and dendritic cell infiltration in gastric cancer. Cancer Letters, v.159, p. 103-108, 2000.

ITOH, T.L. et al. Structural basis for the activation of PPAR gamma by oxidized fatty acids. Nat Struct Mol Biol, v. 15, n. 9, p.924-31, 2008.

JIANG,W. G.; JOSNEB, A.; MANSEL, R. E. Levels of expression of lipoxygenases and cyclooxygenase-2 in human breast cancer. Prostaglandins, Leukotrienes and Essential Fatty Acids, v.69, p. 275-281, 2003.

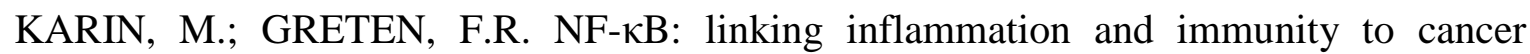
development and progression. Nature Reviews Immunology. v.5, p. 749-759, 2005.

KELAVKAR, U.P. Overexpression of 15-lipoxygenase-1 in PC-3 human prostate cancer cells increases tumorigenesis. Carcinogenesis, v. 22, p. 1765-1773, 2001.

KERSTEN, S.; DESVERGNE, B.; WAHLI, W. Roles of PPARs in health and disease. Nature. v.405, n. 6785, p.421-4, May 252000.

KOBAYASHI, Y. et al. Physiological levels of 15-deoxy-Delta12,14-prostaglandin J2 prime eotaxin-induced chemotaxis on human eosinophils through peroxisome proliferator-activated receptor-gamma ligation. J Immunol., v. 175, n. 9, p.5744-50, Nov 1, 2005.

LEHMANN, J. M. et al. An antidiabetic thiazolidinedione is a high affinity ligand for peroxisome proliferator receptor gamma (PPAR gamma). J Biol Chem. v. 270, n. 22, p.12953-6, 1997. 
LI, Y.; et al. Molecular recognition of nitrated fatty acids by PPAR $\gamma$. Nature structural \& molecular biology. v. 15, n. 8, p. 865-867, 2008.

LIANG, Y. C. et al. Suppression of inducible cyclooxygenase and nitric oxide synthase through activation of peroxisome proliferator-activated receptor gamma by flavonoids in mouse macrophages. Febs Lett, v. 496, p.12-18, 2001.

LIBERATO, M.; et al. Medium chain fatty acids are selective peroxisome proliferator activated receptor (PPAR) c activators and pan-PPAR partial agonists. Plos one. v. 7, n. 5, 2012.

LIU, X. H.; CONNOLLY, J. M.; ROSE, D. P. Eicosanoids as mediators of linoleic acidstimulated invasion and type IV collagenase production by a metastatic human breast cancer cell line. Clin. Exp. Metast. v.14, p. 145-152, 1996.

LIU, X. H.; CONNOLLY, J. M.; ROSE, D. P. The 12-lipoxygenase gene transfected MCF-7 human breast cancer cell line exhibits estrogen-independent, but estrogen and omega- 6 fatty acid stimulated proliferation in vitro, and enhanced growth in athymic nude mice. Cancer Lett, v.109, p.223-230, 1996.

LIU, P. et al. Chinese ovary K2 cell lipid droplets appear to be metabolic organelles involved in membrane traffic. J Biol Chem. v. 279, n. 5, p. 3787-92, 2004.

LOOSE, D.; VAN DE WIELE, C. The immune system and cancer. Cancer Biotherapy \&Radiopharmaceuticals, v. 24. n. 3, p. 369-376, 2009.

MARTIN, S; PARTON, G. Caveolin, cholesterol, and lipid bodies. Semin Cell Dev Biol. v.16, n. 2, p.163-74, 2005.

MATKOWSKYJ, K. A. et al. Dysplastic Lesions in Inflammatory Bowel Disease: Molecular Pathogenesis to Morphology. Archives of Pathology \& Laboratory Medicine, v. 137, n. 3, p. 338-350, mar 2013.

MAYA-MONTEIRO, C. M. et al. Leptin induces macrophagelipid body formation by a phsphatidylinositol 3 kinase and mammalian target of rapamycin-dependent mechanism. J Biol Chem. v. 283, n. 4, p. 2203-10, 2008.

MEHTA, R. G.; MURILLO, G.; NAITHANI, R.; PENG, X. Cancer chemoprevention by natural products: how far have we come? Pharm. Res., v. 27, p. 950-961, 2010.

MORGAN, M.; LIU, Z. Crosstalk of reactive oxygen species and NF- $\kappa B$ signaling. Cell Research, v. 21, n.1, p.103-115, 2011.

NETTLES, K. Insights into PPAR $\gamma$ from structures with endogenous and covalently bound ligands. Nature structural \& molecular biology. v. 15, n. 9, p. 893-895, 2008.

OliveirA, P. A. et al . Chemical carcinogenesis. An. Acad. Bras. Ciênc., Rio de Janeiro, v.79, n.4, Dec. 2007. 
PAL, T.; JOSHI, H.; RAMAA, C. S. Design and Development of Oxazol-5-Ones as Potential Partial PPAR- $\gamma$ Agonist Against Cancer Cell Lines. Anti-Cancer Agents in Medicinal Chemistry, v.14, p. 872-883, 2014.

PARRETT, M. L. et al. Cyclooxygenase-2 gene expression in human breast cancer. Int. J. Oncol., v.10, p. 503-507, 1997.

PERKINS, N.; GILMORE, T. Good cop, bad cop: the different faces of NF-кB. Cell Death and Differentiation, v.13, p.759-772, 2006.

REIMAN, J.M.; KMIECIAK, M.; MANJILI, M.H.; KNUTSON,K.L. Tumor immunoediting and immunosculpting pathways to cancer progression. Semin. Cancer. Biol, v.17, p. 275-287, 2007.

REMELS, A. H. et al. PPARgamma inhibits NF-kappaB-dependent transcriptional activation in skeletal muscle. Am J Physiol Endocrinol Metab., v.297, n.1, p. 17483, 2009.

RICOTE, M.; GLASS, C.K. PPARs and molecular mechanisms of transrepression. Biochem Biophys Acta., Mar, 12. 2007.

SAADATMAND, S. et al. Relevance and efficacy of breast cancer screening in BRCA1 and BRCA2 mutation carriers above 60 years; a national cohort study. Int J Cancer., v. 135, n. 12 , p. $2940-9$, dec 15.2014.

SAEZ, E. PPAR gamma signaling exacerbates mammary gland development. Genes Dev, v. 18, n. 5, p. 528-540, 2004.

SCHREIBER R. D.; OLD L. J.; SMYTH, M. J. Cancer immunoediting: integrating immunity's roles in cancer suppression and promotion. Science, v. 331, p. 1565-70, 2011.

SCHULTZ, D. et al. Anacardic acid inhibits estrogen receptor alpha-DNA binding and reduces target gene transcription and breast cancer cell proliferation. Molecular cancer therapeutics, v. 9, n.3, p.594-605, 2010.

SHASHNI, B. et al. Coffee component hydroxyl hydroquinone (HHQ) as a putative ligand for PPAR gamma and implications in breast cancer. BMC Genomics, v.14, p. $1-16,2013$.

SHI, Y.; EVANS, J. E.; ROCK, K. L. Molecular identification of a danger signal that alerts the immune system to dying cells. Nature, v. 425, p. 516-521, 2003. 
SUBBARAMAIAH, K. et al. Transcription of cyclooxygenase-2 is enhanced in transformed mammary epithelial cells. Cancer Res, v.56, p.4424-4429, 1996.

SURH, Y. J. Cancer chemoprevention with dietary phytochemicals. Nat. Rev. Cancer., v. 3, p. 768-780, 2003.

TAYLOR, P. M. Breast cancer cell-derived EMMPRIN stimulates fibroblast MMP2 release through a phospholipase $\mathrm{A}(2)$ and 5-lipoxygenase catalyzed pathway. Oncogene, v. 21, p. 5765-5772, 2002.

THOMAS, L. Reactions to homologous tissue antigens in relation to hypersensitivity. Cellular and humoral aspects of the hypersensitive states. Ed. Lawrence, H.S. Hoeber-Harper, Nova York. p. 529-532, 1959.

WILLSON, TM; LAMBERT, MH; KLIEVER, SA. Peroxisome proliferator-activated receptor gamma and metabolic disease. Annu Rev Biochem. n. 70, p. 341-367, 2001.

WOLFLE, D. et al. Induction of cyclooxygenase expression and enhancement of malignant cell transformation by 2,3, 7, 8-tetrachlorodibenzo-pdioxin. Carcinogenesis, v.21, p. 15-21, 2000.

YILMAZ, M.; CHRISTOFORI, G. mechanisms of motility in metastasizing cells. Mol Cancer Res, v. 8, n. 5, p. 629-642, 2010.

YU, S.; REDDY, J.K. Transcription coactivators for peroxisome proliferator-activated receptor. Biochem Biophys Acta, Jan 20. 2007.

YU, H. et al. Induction of G1 phase arrest and apoptosis in MDA-MB-231breast cancer cells by troglitazone, a synthetic peroxisome proliferator-activated receptor g (PPARg) ligand. Cell Biology International, v. 32, p. 906-912, 2008.

ZAYTSEVA, Y. et al. Down-regulation of PPARgamma I suppresses cell growth and induces apoptosis in MCF-7 breast cancer cells. Molecular Cancer, v.7, n. 90, p. 1$13,2008$.

ZAYTSEVA, Y.; WALLIS, N.; SOUTHARD, C.; KILGORE, M. The PPAR $\gamma$ Antagonist T0070907 Suppresses Breast Cancer Cell Proliferation and Motility via Both PPAR $\gamma$ dependent and -independent Mechanisms. Anticancer Research, v. 31, p. 813-824, 2011.

ZITVOGEL, L.; TESNIERE, A.; KROEMER, G. Cancer despite immunosurveilance: immunoselection and immunosubversion. Nature Reviews Immunology, v. 6, n. 10, p.715-27, Oct 2006. 
